\title{
Covalent Stabilization of Antibody Recruitment Enhances Immune Recognition of Cancer Targets
}

\author{
Eden Kapcan ${ }^{\S}$, Benjamin Lake ${ }^{\S}$, Zi Yang ${ }^{\S}$, Ali Zhang ${ }^{+}$, Matthew S. Miller ${ }^{+}$, and Anthony F. Rullo ${ }^{\S *}$ \\ $\S 1$.Department of Medicine 2. Department of Chemistry and Chemical Biology. ${ }^{+3}$. Michael G. DeGroote Institute for \\ Infectious Disease Research, Department of Biochemistry and Biomedical sciences. McMaster University, 1280 Main \\ Street West, ON, Canada.
}

Summary: Antibody recruiting molecules (ARMs) represent an important class of "proximity inducing" chemical tools with therapeutic potential. ARMs function by simultaneously binding to a hapten specific serum antibody (Ab) (e.g. anti-dinitrophenyl (DNP)) and a cancer cell surface protein, enforcing their proximity. ARM anti-cancer efficacy depends on the formation of ARM:Ab complexes on the cancer cell surface which activate immune cell recognition and elimination of the cancer cell. Problematically, ARM function in human patients may be limited by conditions that drive the dissociation of ARM:Ab complexes; namely intrinsically low binding affinity and/or low concentrations of anti-hapten antibodies in human serum. To address this potential limitation, we previously developed a covalent ARM (cARM) chemical tool that eliminates the ARM:antibody equilibrium through a covalent linkage. In the current study we set out to determine to what extent maximizing the stability of these ARM:antibody complexes via cARMs enhances target immune recognition. We observe cARMs significantly increase target immune recognition relative to ARMs across a range of therapeutically relevant antibody concentrations. These findings demonstrate that ARM therapeutic function can be dramatically enhanced by increasing the stability of ARM:antibody complexes localized on cancer cells.

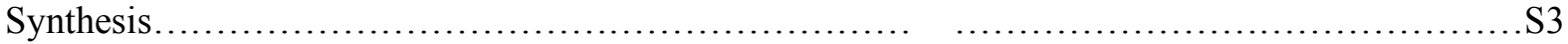

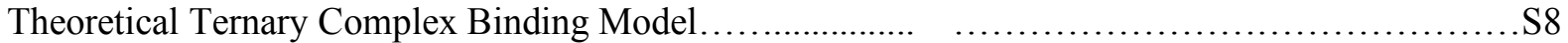

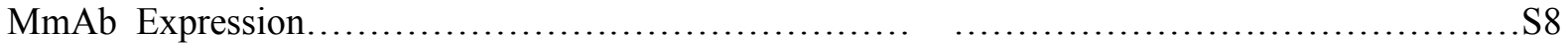

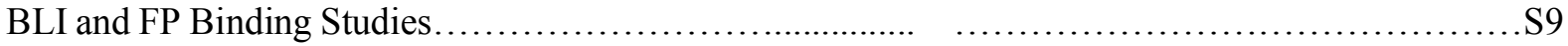

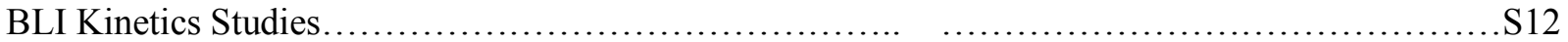

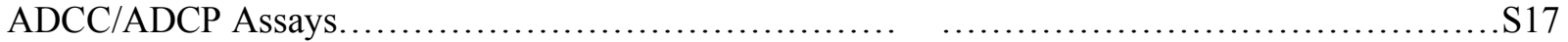

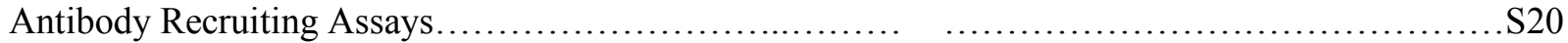

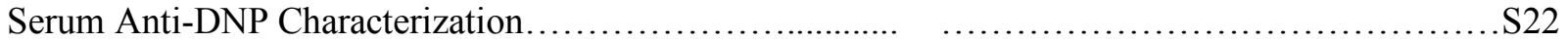

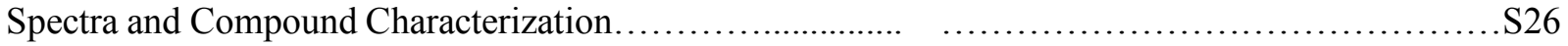




\section{$\underline{\text { Experimental Procedures }}$}

\section{General materials and methods for organic synthesis and instrumentation}

All chemical reagents and solvents were obtained from commercial suppliers (Sigma Aldrich, Broadpharm) and used without further purification. Thin layer chromatography (TLC) was performed on silica gel precoated aluminium sheets (Silicycle) and visualized by fluorescence quenching, ninhydrin, and potassium permanganate staining. All column chromatography purification was conducted using a Buchi Pure C-810 Flash purification system using normal phase silica gel (Buchi) or reverse phase $\mathrm{C} 18$ columns (Buchi). ${ }^{1} \mathrm{H}$, ${ }^{13} \mathrm{C}$, and ${ }^{1} \mathrm{H}-{ }^{1} \mathrm{H}$ COSY NMR spectra were all recorded in deuterated dimethyl sulfoxide $\left(\left(\mathrm{CD}_{3}\right)_{2} \mathrm{SO}\right)$ or deuterated chloroform $\left(\mathrm{CDCl}_{3}\right)$ on a Bruker $700 \mathrm{MHz}$ spectrometer. Electrospray ionization quadrupole fourier transform mass spectroscopy (ESI-MS) data was obtained using a Waters QUATTRO mass spectrometer, while LCMS data was obtained on a Agilent-Sciex QTRAP system or a LTQ Orbitrap XL system using a gradient of $95: 5$ to $5: 95$ water $(0.1 \%$ formic acid $)$ :ACN $(0.1 \%$ formic acid $)$. HRMS-ESI was obtained with a BRUKER MicroTOF II mass spectrometer. Where indicated, a ThermoFisher DIONEX UltiMate 3000 UHPLC + was used for HPLC purification with a gradient of 95:5 to 5:95 water $(0.1 \%$ formic acid): $\mathrm{ACN}(0.1 \%$ formic acid).

Note: Synthesis of compounds 1, 2, cARM 3, and ARM 4 (see Figure 2, main manuscript) adapted from reference $1 .{ }^{1}$ Optimized milligram scale preparation of cARM 3 (described below) enabled for complete characterization included below. 
Scheme S1. Synthesis of compounds cARM 5, ARM6.
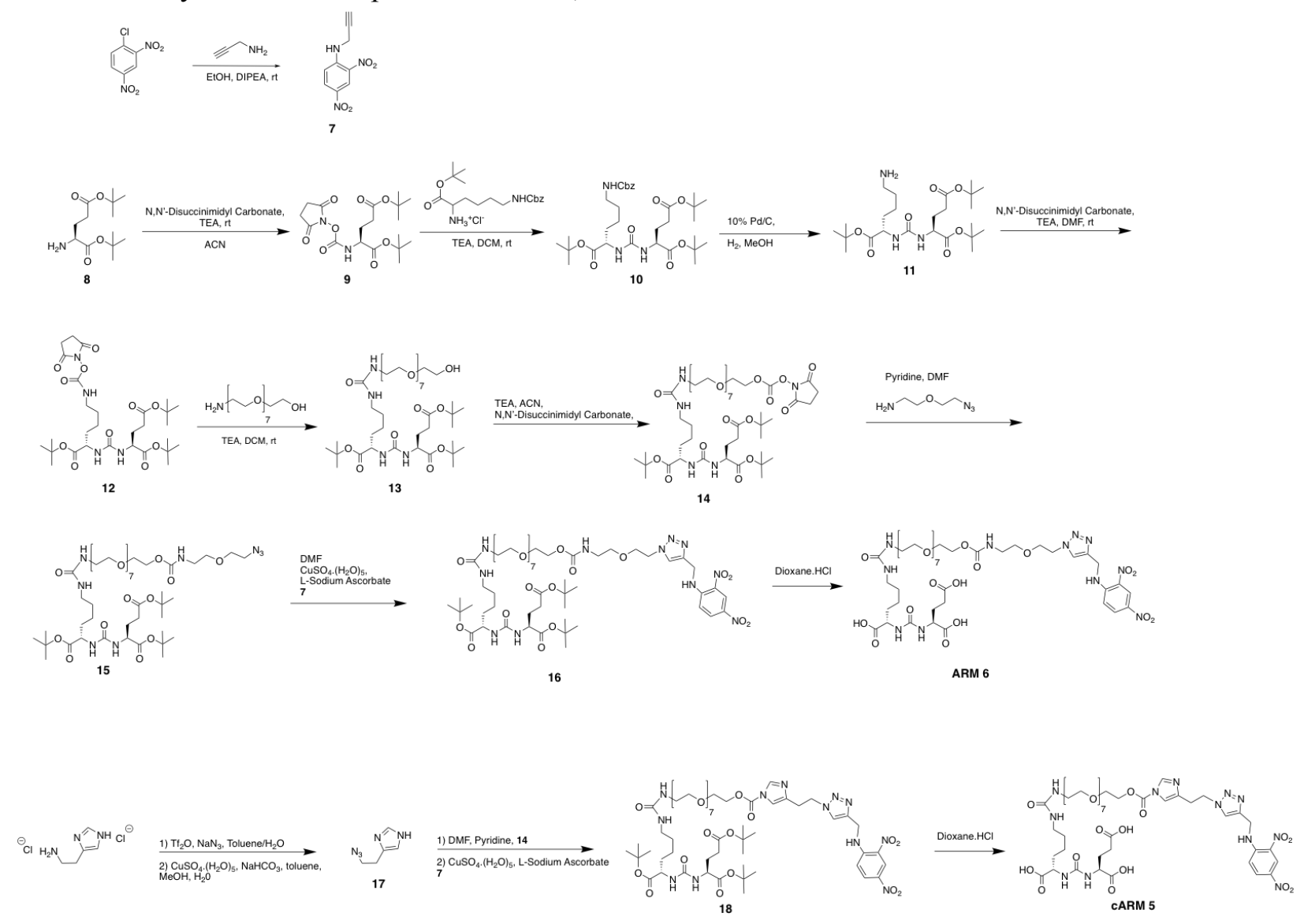

Note: Synthesis of compounds $\mathbf{8 - 1 3}$ adapted from reference $1 .^{1}$

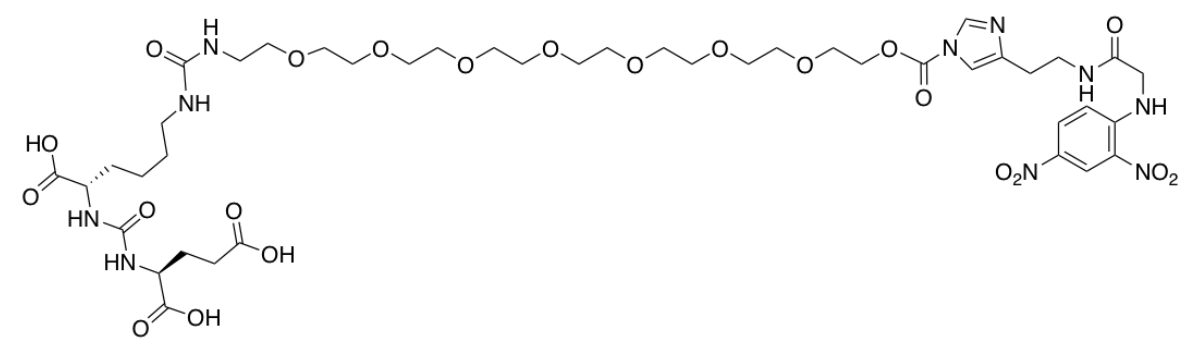

cARM 3. Tri-tert-butyl cARM3 (27.3 mg, $0.022 \mathrm{mmol})$ was dissolved in $2 \mathrm{~mL}$ Dioxane.HCl (4M) under argon and stirred for 4 hours. The solution was concentrated under vacuum and resuspended in $2.2 \mathrm{~mL}$ 
(30\% ACN: $70 \% \mathrm{H}_{2} \mathrm{O}$ ) and purified by HPLC. Product fractions were neutralized to $\mathrm{pH} 7$ with sodium bicarbonate solution (neutralization of formic acid post HPLC dramatically improved synthetic yield). This solution was lyophilized to yield cARM3 as a yellow oil. CARM3 was suspended in DMSO and concentration measured against a DNP-glycine standard curve to determine cARM3 yield $(3.17 \mathrm{mg}, 13.4 \%$ yield, loss due to hydrolysis in workup). ${ }^{1} \mathrm{H} \mathrm{NMR}\left(700 \mathrm{MHz},\left(\mathrm{CD}_{3}\right)_{2} \mathrm{SO}\right) \delta 9.09$ (t, $\left.J=5.5 \mathrm{~Hz}, 1 \mathrm{H}\right), 8.87$ $(\mathrm{d}, J=2.7 \mathrm{~Hz}, 1 \mathrm{H}), 8.28(\mathrm{t}, J=5.6 \mathrm{~Hz}, 1 \mathrm{H}), 8.25(\mathrm{dd}, J=2.7,9.6 \mathrm{~Hz}, 1 \mathrm{H}), 8.14(\mathrm{~s}, 1 \mathrm{H}), 7.33(\mathrm{~s}, 1 \mathrm{H}), 6.91$ $(\mathrm{d}, J=9.6 \mathrm{~Hz}, 1 \mathrm{H}), 6.37(\mathrm{~m}, 1 \mathrm{H}), 6.23(\mathrm{~m}, 1 \mathrm{H}), 5.93(\mathrm{t}, J=5.4 \mathrm{~Hz}, 1 \mathrm{H}), 5.85(\mathrm{t}, J=5.2 \mathrm{~Hz}, 1 \mathrm{H}), 4.46(\mathrm{~m}$, 2H), $4.13(\mathrm{~d}, J=5.4 \mathrm{~Hz}, 2 \mathrm{H}), 4.00(\mathrm{~m}, 2 \mathrm{H}), 3.74(\mathrm{~m}, 2 \mathrm{H}), 3.57(\mathrm{~m}, 2 \mathrm{H}), 3.49(\mathrm{~m}, 22 \mathrm{H}), 3.35(\mathrm{~m}, 4 \mathrm{H}), 3.11$ $(\mathrm{m}, 2 \mathrm{H}), 2.93(\mathrm{~m}, 2 \mathrm{H}), 2.64(\mathrm{t}, J=7.1 \mathrm{~Hz}, 2 \mathrm{H}), 2.22(\mathrm{~m}, 2 \mathrm{H}), 1.74(\mathrm{~m}, 2 \mathrm{H}), 1.55(\mathrm{~m}, 2 \mathrm{H}), 1.32(\mathrm{~m}, 2 \mathrm{H})$, 1.26 (m, 2H). ${ }^{13} \mathrm{C}$ NMR $\left(176 \mathrm{MHz},\left(\mathrm{CD}_{3}\right)_{2} \mathrm{SO}\right) \delta 174.6,174.2,174.1,167.0,157.9,157.1,148.1,147.7$, 140.9, 136.7, 135.1, 130.1, 129.8, 123.2, 115.6, 113.5, 70.0, 69.7, 69.5, 67.7, 67.0, 52.3, 52.2, 45.7, 40.3, 38.0, 31.8, 29.6, 27.5, 22.6. HRMS-ESI $[\mathrm{M}+\mathrm{H}]^{+} m / z$ calc for $\left[\mathrm{C}_{43} \mathrm{H}_{67} \mathrm{~N}_{10} 0_{22}\right] 1075.44$, found 1075.46017 .

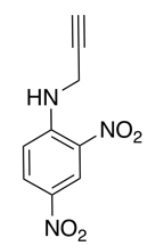

Dinitrophenol-propargyl intermediate 7. To a solution of 1-Chloro-2,4-Dinitrobenzene (318 mg, $1.57 \mathrm{mmol})$ and propargylamine $(193.5 \mathrm{uL}, 3.02 \mathrm{mmol})$ in ethanol $(15 \mathrm{~mL})$, DIPEA $(526 \mathrm{uL}, 3.02 \mathrm{mmol})$ was added. This solution was mixed overnight and dried under air stream. This crude product was purified on a $12 \mathrm{~g}$ buchi flashpure silica column with a gradient increasing from 75:25 to 0:100 Hex:DCM. Product fractions were collected and dried, then resuspended in DCM and crashed out in hexanes. The precipitate was collected via centrifugation, and dried to yield $7\left(152.7 \mathrm{mg}, 44 \%\right.$ yield) as a yellow solid. ${ }^{1} \mathrm{H}$ NMR (700 $\left.\mathrm{MHz},\left(\mathrm{CD}_{3}\right)_{2} \mathrm{SO}\right) \delta 9.05(\mathrm{~s}, 1 \mathrm{H}), 8.88(\mathrm{~d}, J=2.7 \mathrm{~Hz}, 1 \mathrm{H}), 8.38(\mathrm{dd}, J=2.7,9.6 \mathrm{~Hz}, 1 \mathrm{H}), 7.25(\mathrm{~d}, J=9.6$ $\mathrm{Hz}, 1 \mathrm{H}), 4.35$ (s, 2H), $3.31(\mathrm{~s}, 1 \mathrm{H}) .{ }^{13} \mathrm{C} \mathrm{NMR}\left(176 \mathrm{MHz},\left(\mathrm{CD}_{3}\right)_{2} \mathrm{SO}\right) \delta 147.2,135.5,130.4,129.9,123.3$, $115.6,79.3,74.7,32.3$.

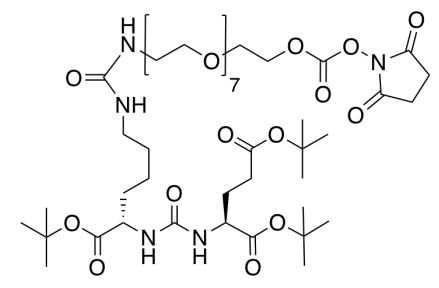

Carbonate Intermediate 14. Alcohol derivative $13(232.9 \mathrm{mg}, 0.264 \mathrm{mmol})$ and $N, N$ '-Disuccinimidyl Carbonate $(101 \mathrm{mg}, 0.394 \mathrm{mmol})$ were dissolved in $2 \mathrm{~mL}$ of acetonitrile. Triethylamine $(55 \mathrm{uL}, 0.394 \mathrm{mmol})$ was then added, and the mix was stirred for 2.5 hours. This mix was injected on a $40 \mathrm{~g}$ flash $\mathrm{C} 18$ column, pure fractions were collected and acetonitrile was removed under vacuum. The product was extracted into EtOAc, dried over anhydrous $\mathrm{Mg}_{2} \mathrm{SO}_{4}$ and concentrated under vacuum to yield 14 (164.2mg, 60.7\% yield) as a clear oil. ${ }^{1} \mathrm{H}$ NMR $\left(700 \mathrm{MHz}, \mathrm{CDCl}_{3}\right) \delta 5.63(\mathrm{~s}, 1 \mathrm{H}), 5.51(\mathrm{~s}, 1 \mathrm{H}), 5.45(\mathrm{~s}, 1 \mathrm{H}), 5.35(\mathrm{~s}, 1 \mathrm{H}), 4.45(\mathrm{~m}$, $2 \mathrm{H}), 4.31(\mathrm{~m}, 1 \mathrm{H}), 4.22(\mathrm{~m}, 1 \mathrm{H}), 3.78(\mathrm{~m}, 2 \mathrm{H}), 3.64(\mathrm{~m}, 24 \mathrm{H}), 3.55(\mathrm{~m}, 2 \mathrm{H}), 3.36(\mathrm{~m}, 2 \mathrm{H}), 3.16(\mathrm{~m}, 2 \mathrm{H})$, $2.84(\mathrm{~s}, 4 \mathrm{H}), 2.31(\mathrm{~m}, 2 \mathrm{H}), 1.93(\mathrm{~m}, 2 \mathrm{H}), 1.68(\mathrm{~m}, 2 \mathrm{H}), 1.42(\mathrm{~m}, 29 \mathrm{H}), 1.35(\mathrm{~m}, 2 \mathrm{H}) .{ }^{13} \mathrm{C}$ NMR $(176 \mathrm{MHz}$, 
$\left.\mathrm{CDCl}_{3}\right) \delta 172.7,172.6,172.5,168.7,159.2,157.4,151.7,82.0,81.4,80.5,70.5,68.4,53.5,53.0,40.4,39.2$, $31.8,31.7,29.8,28.5,28.2,28.1,25.6,22.1$. LCMS confirmed correct expected mass of product. MS-ESI $[\mathrm{M}+\mathrm{H}]^{+} m / z$ calc for $\left[\mathrm{C}_{46} \mathrm{H}_{82} \mathrm{~N}_{5} 0_{20}\right] 1024.55$, found 1024.5426 .

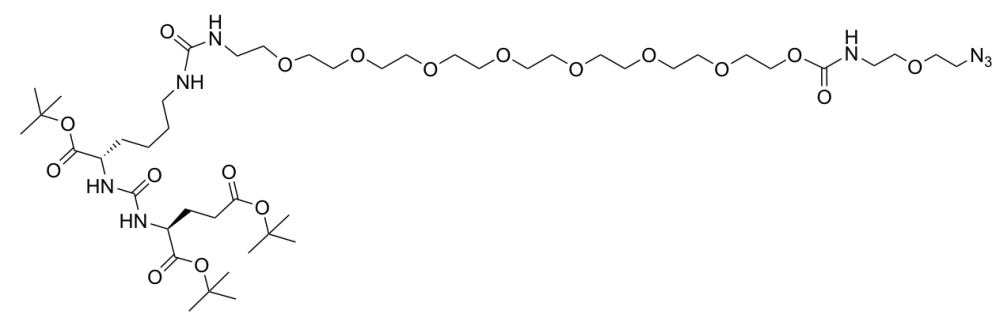

Intermediate 15 of ARM6. Compound $14(75 \mathrm{mg}, 0.073 \mathrm{mmol})$ was resuspended in toluene and dried under vacuum. Separately, azido-PEG1-amine $(22.6 \mathrm{mg}, 0.17 \mathrm{mmol})$ was resuspended in toluene and dried under vacuum. Azido-PEG1-amine was dissolved in anhydrous DMF $(2 \mathrm{~mL})$ and added to $\mathbf{1 4}$ under an argon atmosphere. Pyridine $(80 \mathrm{uL}, 0.994 \mathrm{mmol})$ was then added, and the solution was mixed overnight and purified via HPLC to yield $15\left(19.1 \mathrm{mg}, 25.2 \%\right.$ yield) as a yellow oil. ${ }^{1} \mathrm{H}$ NMR $\left(700 \mathrm{MHz}, \mathrm{CDCl}_{3}\right) \delta 5.64$ $(\mathrm{m}, 1 \mathrm{H}), 5.51(\mathrm{~m}, 1 \mathrm{H}), 5.45(\mathrm{~s}, 1 \mathrm{H}), 5.33(\mathrm{~m}, 1 \mathrm{H}), 4.31(\mathrm{~m}, 1 \mathrm{H}), 4.22(\mathrm{~m}, 3 \mathrm{H}), 3.64(\mathrm{~m}, 28 \mathrm{H}), 3.55(\mathrm{~m}, 4 \mathrm{H})$, $3.37(\mathrm{~m}, 6 \mathrm{H}), 3.16(\mathrm{~m}, 2 \mathrm{H}), 2.31(\mathrm{~m}, 2 \mathrm{H}), 1.94(\mathrm{~m}, 2 \mathrm{H}), 1.70(\mathrm{~m}, 2 \mathrm{H}), 1.43(\mathrm{~m}, 29 \mathrm{H}), 1.35(\mathrm{~m}, 2 \mathrm{H}) .{ }^{13} \mathrm{C}$ NMR $\left(176 \mathrm{MHz}, \mathrm{CDCl}_{3}\right) \delta 172.6,172.5,172.4,159.1,157.2,156.5,81.8,81.2,80.4,70.5,64.0,53.4,52.9$, $40.8,40.2,39.1,31.6,29.7,28.1,22.0$.

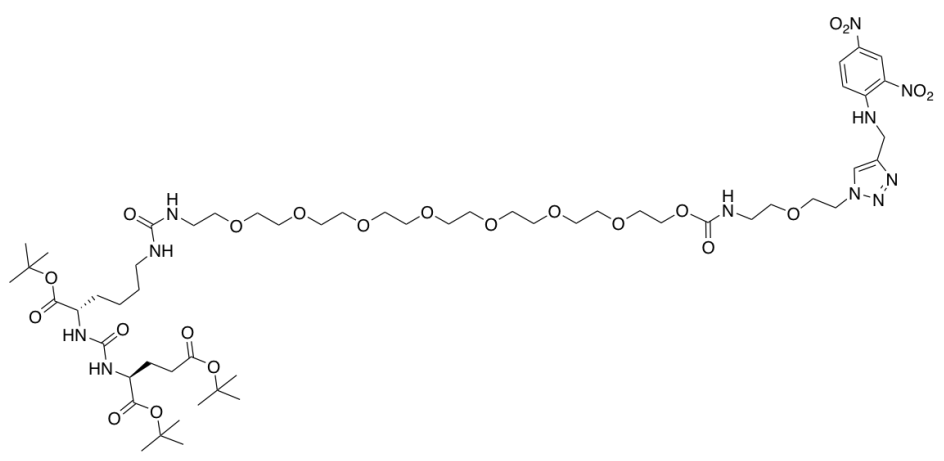

Intermediate 16 of ARM6. Intermediate 7 (10.1 $\mathrm{mg}, 0.046 \mathrm{mmol})$, L-sodium ascorbate (11.4mg, 0.058mg), Copper sulfate pentahydrate $(5.6 \mathrm{mg}, 0.022 \mathrm{mmol})$, and intermediate $15(19.1 \mathrm{mg}, 0.018 \mathrm{mmol})$ were dissolved in $1 \mathrm{~mL}$ DMF and left to stir overnight. The mixture was purified via HPLC to yield 16 (13.5mg, 59.5\% yield). ${ }^{1} \mathrm{H}$ NMR $\left(700 \mathrm{MHz},\left(\mathrm{CD}_{3}\right)_{2} \mathrm{SO}\right) \delta 9.29(\mathrm{t}, J=6.0 \mathrm{~Hz}, 1 \mathrm{H}), 8.87(\mathrm{~d}, J=2.7 \mathrm{~Hz}, 1 \mathrm{H})$, $8.28(\mathrm{~d}, J=2.7,9.6 \mathrm{~Hz}, 1 \mathrm{H}), 8.04(\mathrm{~s}, 1 \mathrm{H}), 7.31(\mathrm{~d}, J=9.6 \mathrm{~Hz}, 1 \mathrm{H}), 7.17(\mathrm{t}, J=5.7 \mathrm{~Hz}, 1 \mathrm{H}), 6.28(\mathrm{~m}, 2 \mathrm{H})$, $5.91(\mathrm{t}, J=5.7 \mathrm{~Hz}, 1 \mathrm{H}), 5.79(\mathrm{t}, J=5.7 \mathrm{~Hz}, 1 \mathrm{H}), 4.79(\mathrm{~d}, J=6.0 \mathrm{~Hz}, 2 \mathrm{H}), 4.48(\mathrm{t}, J=5.2 \mathrm{~Hz}, 2 \mathrm{H}), 4.03(\mathrm{~m}$, $3 \mathrm{H}), 3.94(\mathrm{~m}, 1 \mathrm{H}), 3.74(\mathrm{t}, J=5.2 \mathrm{~Hz}, 2 \mathrm{H}), 3.54(\mathrm{t}, J=4.7 \mathrm{~Hz}, 2 \mathrm{H}), 3.50(\mathrm{~m}, 24 \mathrm{H}), 3.35(\mathrm{~m}, 4 \mathrm{H}), 3.12(\mathrm{~m}$, 2H), $3.03(\mathrm{~m}, 2 \mathrm{H}), 2.94(\mathrm{~m}, 2 \mathrm{H}), 2.21(\mathrm{~m}, 2 \mathrm{H}), 1.76(\mathrm{~m}, 2 \mathrm{H}), 1.54(\mathrm{~m}, 2 \mathrm{H}), 1.38(\mathrm{~m}, 27 \mathrm{H}), 1.34(\mathrm{~m}, 2 \mathrm{H})$, 1.25 (m, 2H). ${ }^{13} \mathrm{C}$ NMR $\left(176 \mathrm{MHz},\left(\mathrm{CD}_{3}\right)_{2} \mathrm{SO}\right) \delta 172.2,171.8,171.3,157.9,157.0,156.1,147.8,142.9$, 135.1, 130.0, 129.8, 123.5, 123.4, 115.6, 80.5, 80.2, 79.6, 70.1, 69.7, 69.6, 68.7, 68.3, 63.1, 53.0, 52.1, $49.4,38.3,31.7,30.8,29.7,27.5,22.4$. LCMS confirmed correct expected mass of product. MSESI $[\mathrm{M}+\mathrm{H}]^{+} m / z$ calc for $\left[\mathrm{C}_{55} \mathrm{H}_{94} \mathrm{~N}_{11} 0_{22}\right] 1260.65$, found 1260.7 . 


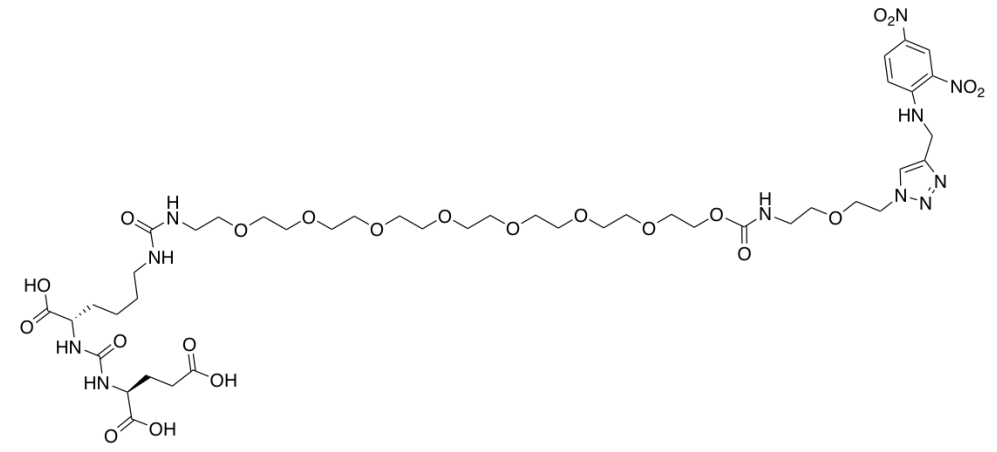

$\underline{\boldsymbol{A R M 6}}$. Intermediate 16 was dried extensively under reduced pressure, and the flask backfilled with argon. Dioxane. $\mathrm{HCl}(2 \mathrm{~mL}, 4 \mathrm{M})$ was added, and the solution stirred for 3 hours. Dioxane.HCl was removed under vacuum overnight to yield ARM 6 (100\% yield). ${ }^{1} \mathrm{H}$ NMR (700 MHz, $\left.\left(\mathrm{CD}_{3}\right)_{2} \mathrm{SO}\right) \delta 9.29$ $(\mathrm{t}, J=5.9 \mathrm{~Hz}, 1 \mathrm{H}), 8.86(\mathrm{~d}, J=2.7 \mathrm{~Hz}, 1 \mathrm{H}), 8.27(\mathrm{dd}, J=2.7,9.6 \mathrm{~Hz}, 1 \mathrm{H}), 8.04(\mathrm{~s}, 1 \mathrm{H}), 7.31(\mathrm{~d}, J=9.6$ $\mathrm{Hz}, 1 \mathrm{H}), 7.17(\mathrm{t}, J=5.6 \mathrm{~Hz}, 1 \mathrm{H}), 6.32(\mathrm{~m}, 2 \mathrm{H}), 4.79(\mathrm{~d}, J=6.0 \mathrm{~Hz}, 2 \mathrm{H}), 4.48(\mathrm{t}, J=5.2 \mathrm{~Hz}, 2 \mathrm{H}), 4.08$ $(\mathrm{m}, 1 \mathrm{H}), 4.02(\mathrm{~m}, 3 \mathrm{H}), 3.74(\mathrm{t}, J=5.2 \mathrm{~Hz}, 2 \mathrm{H}), 3.54(\mathrm{~m}, 2 \mathrm{H}), 3.49(\mathrm{~m}, 24 \mathrm{H}), 3.35(\mathrm{~m}, 4 \mathrm{H}), 3.11(\mathrm{t}, J=$ $5.7 \mathrm{~Hz}, 2 \mathrm{H}), 3.03(\mathrm{~m}, 2 \mathrm{H}), 2.94(\mathrm{t}, J=6.9 \mathrm{~Hz}, 2 \mathrm{H}), 2.25(\mathrm{~m}, 2 \mathrm{H}), 1.81(\mathrm{~m}, 2 \mathrm{H}), 1.57(\mathrm{~m}, 2 \mathrm{H}), 1.33(\mathrm{~m}$, 2H), $1.25(\mathrm{~m}, 2 \mathrm{H}) .{ }^{13} \mathrm{C}$ NMR (176 MHz, $\left.\left(\mathrm{CD}_{3}\right)_{2} \mathrm{SO}\right) \delta 174.4,174.0,173.6,157.8,157.1156 .1,147.8$, 142.9, 135.1, 130.0, 129.8, 123.5, 123.3, 115.5, 70.0, 69.6, 69.4, 68.8, 68.7, 68.2, 63.0, 52.2, 51.5, 49.3, $38.3,31.7,29.8,29.6,27.4,22.5$. HRMS-ESI $[\mathrm{M}+\mathrm{H}]^{+} m / z$ calc for $\left[\mathrm{C}_{43} \mathrm{H}_{70} \mathrm{~N}_{11} 0_{22}\right] 1092.46$, found 1092.49426.

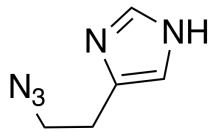

Intermediate 17 of $\boldsymbol{c A R M 5}$. Sodium azide $(554.6 \mathrm{mg}, 8.532 \mathrm{mmol})$ was dissolved in $1.37 \mathrm{~mL}$ water followed by addition of $1.37 \mathrm{~mL}$ toluene. The mixture was cooled to $0^{\circ} \mathrm{C}$. Triflic anhydride $(896 \mathrm{uL}, 5.326 \mathrm{mmol}$ ) was added to the stirring mixture dropwise, and allowed to stir for 30 minutes (on ice). The mixture was stirred further for 2 hours at $10^{\circ} \mathrm{C}$. This was a biphasic solution with top translucent colourless, and bottom clear colourless layers. To this solution, $6 \mathrm{~mL}$ of saturated sodium bicarbonate was added with stirring until bubbling stopped (about 10 minutes). This solution was washed $2 \mathrm{x}$ with $1.37 \mathrm{~mL}$ toluene. The organic layers were pooled (about $3.9 \mathrm{~mL}$ ) and added to a separately prepared solution of histamine dihydrochloride $(226.6 \mathrm{mg}, 1.215 \mathrm{mmol})$, sodium bicarbonate (512.6mg, 6.102 $\mathrm{mmol})$, and copper sulfate pentahydrate $(11 \mathrm{mg}, 0.044 \mathrm{mmol})$ in $1.5 \mathrm{~mL}$ water. To this new mixture, $9.9 \mathrm{~mL} \mathrm{MeOH}$ was added resulting in a homogenous solution. The reaction was left to stir overnight. The solution was dried under reduced pressure (keeping temperature strictly below $25^{\circ} \mathrm{C}$ ), and resuspended in $3 \mathrm{~mL}$ of 20:80 $\mathrm{MeOH}: \mathrm{DCM}$. This was pelleted, and supernatant purified on a $12 \mathrm{~g}$ buchi flashpure silica column. Product fractions were pooled and dried under vacuum to yield $\mathbf{1 7}$ (124.9mg, 75\% yield) as a yellow oil. ${ }^{1} \mathrm{H}$ NMR $\left(700 \mathrm{MHz},\left(\mathrm{CD}_{3}\right)_{2} \mathrm{SO}\right) \delta 7.58(\mathrm{~s}, 1 \mathrm{H}), 6.88(\mathrm{~s}, 1 \mathrm{H}), 3.52(\mathrm{t}$, $J=6.9 \mathrm{~Hz}, 2 \mathrm{H}), 2.76(\mathrm{t}, J=6.9 \mathrm{~Hz}, 2 \mathrm{H}) .{ }^{13} \mathrm{C} \mathrm{NMR}\left(176 \mathrm{MHz},\left(\mathrm{CD}_{3}\right)_{2} \mathrm{SO}\right) \delta 134.9,134.1,120.5,50.2$, 26.6 . 


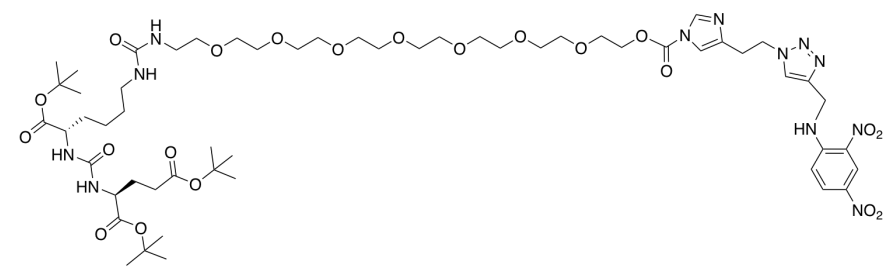

Intermediate 18 cARM5. Compound 14 (102.2mg, 0.1mmol) was resuspended in toluene and dried under vacuum. Separately intermediate $17(16.4 \mathrm{mg}, 0.12 \mathrm{mmol})$ was resuspended in toluene and dried under vacuum. Intermediate 17 was dissolved in anhydrous DMF $(2 \mathrm{~mL})$ and added to $\mathbf{1 4}$ under an argon atmosphere. Pyridine (24uL, $0.298 \mathrm{mmol}$ ) was then added, and the solution was mixed for 3 hours. To this crude mix, intermediate $7(53 \mathrm{mg}, 0.24 \mathrm{mmol})$, L-sodium ascorbate $(59.3 \mathrm{mg}, 0.299 \mathrm{mmol})$, and copper sulfate pentahydrate $(15 \mathrm{mg}, 0.06 \mathrm{mmol})$ were added with additional anhydrous DMF $(1 \mathrm{~mL})$. This mixture was stirred for 1.5 hours and then pelleted. The supernatant was purified via HPLC to yield $\mathbf{1 8}$ (73.4mg, $58 \%$ yield). ${ }^{1} \mathrm{H}$ NMR $\left(700 \mathrm{MHz},\left(\mathrm{CD}_{3}\right)_{2} \mathrm{SO}\right) \delta 9.26(\mathrm{t}, J=5.9 \mathrm{~Hz}, 1 \mathrm{H}), 8.86(\mathrm{~d}, J=2.8 \mathrm{~Hz}, 1 \mathrm{H}), 8.25(\mathrm{dd}$, $J=2.8,9.6 \mathrm{~Hz}, 1 \mathrm{H}), 8.15(\mathrm{~d}, J=1.2 \mathrm{~Hz}, 1 \mathrm{H}), 8.00(\mathrm{~s}, 1 \mathrm{H}), 7.28(\mathrm{~d}, J=0.9 \mathrm{~Hz}, 1 \mathrm{H}), 7.25(\mathrm{~d}, J=9.6 \mathrm{~Hz}$, $1 \mathrm{H}), 6.28(\mathrm{~m}, 2 \mathrm{H}), 5.91(\mathrm{t}, J=5.6 \mathrm{~Hz}, 1 \mathrm{H}), 5.79(\mathrm{t}, J=5.7 \mathrm{~Hz}, 1 \mathrm{H}), 4.76(\mathrm{~d}, J=6.0 \mathrm{~Hz}, 2 \mathrm{H}), 4.61(\mathrm{t}, J=$ $7.1 \mathrm{~Hz}, 2 \mathrm{H}), 4.45(\mathrm{~m}, 2 \mathrm{H}), 4.03(\mathrm{~m}, 1 \mathrm{H}), 3.95(\mathrm{~m}, 1 \mathrm{H}), 3.73(\mathrm{~m}, 2 \mathrm{H}), 3.56(\mathrm{~m}, 2 \mathrm{H}), 3.48(\mathrm{~m}, 22 \mathrm{H}), 3.32$ $(\mathrm{t}, J=5.8 \mathrm{~Hz}, 2 \mathrm{H}), 3.12(\mathrm{~m}, 2 \mathrm{H}), 3.05(\mathrm{t}, J=7.1 \mathrm{~Hz}, 2 \mathrm{H}), 2.94(\mathrm{~m}, 2 \mathrm{H}), 2.21(\mathrm{~m}, 2 \mathrm{H}), 1.76(\mathrm{~m}, 2 \mathrm{H}), 1.53$ $(\mathrm{m}, 2 \mathrm{H}), 1.38(\mathrm{~m}, 27 \mathrm{H}), 1.33(\mathrm{~m}, 2 \mathrm{H}), 1.24(\mathrm{~m}, 2 \mathrm{H}) .{ }^{13} \mathrm{C} \mathrm{NMR}\left(176 \mathrm{MHz},\left(\mathrm{CD}_{3}\right)_{2} \mathrm{SO}\right) \delta 172.2,171.8$, 171.4, 157.9, 157.0, 148.1, 147.8, 142.9, 139.4, 136.9, 135.1, 130.0, 129.8, 123.4, 123.1, 115.6, 114.1, $80.5,80.2,79.7,70.1,69.7,69.5,67.8,67.1,53.0,52.1,48.4,38.4,31.7,30.8,29.7,28.3,27.7$, 27.6, 22.4. MS-ESI $[\mathrm{M}+\mathrm{H}]^{+} m / z$ calc for $\left[\mathrm{C}_{56} \mathrm{H}_{90} \mathrm{~N}_{12} \mathrm{O}_{21}\right] 1267.63$, found 1267.4462 .

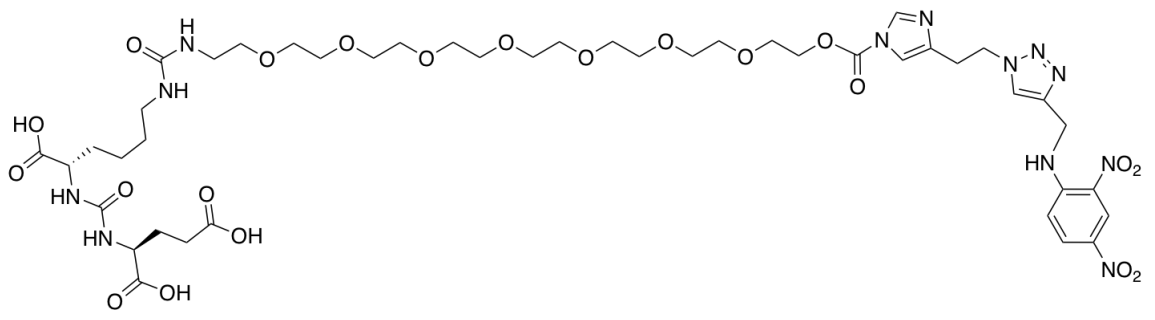

$\underline{\boldsymbol{c} \boldsymbol{A R M 5} .}$ Intermediate $\mathbf{1 8}$ was dried extensively under reduced pressure, and the flask backfilled with argon . Dioxane.HCl (2mL, 4M) was added, and stirred for 2 hours. Dioxane. $\mathrm{HCl}$ was removed under vacuum to yield cARM5. Final product was immediately resuspended in DMSO and aliquoted for use in biological assays. HRMS-ESI $[\mathrm{M}+\mathrm{H}]^{+} m / z$ calc for $\left[\mathrm{C}_{44} \mathrm{H}_{67} \mathrm{~N}_{12} 0_{21}\right] 1099.45$, found 1099.57113 . 


\section{$\underline{\text { Equilibrium Binding Models }}$}

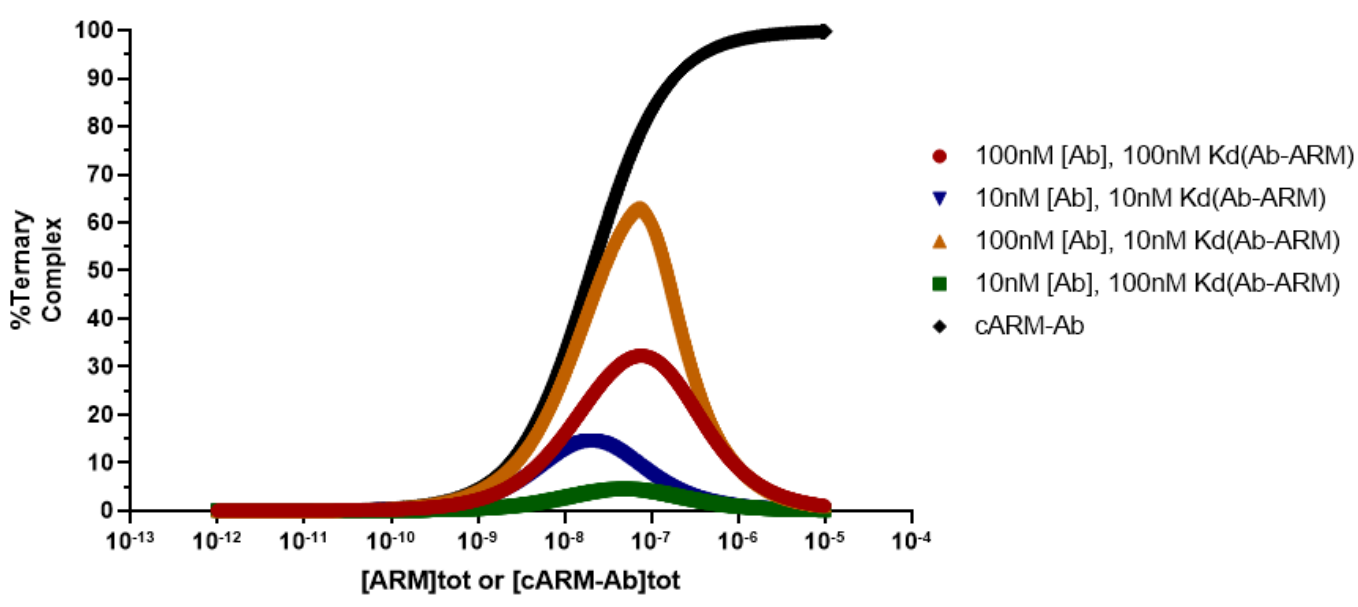

Figure S1. Ternary complex simulation using different concentrations and affinities of antibody. Using a determined PSMA concentration on HEK-PSMA Cells of $0.65 \mathrm{nM}$ (data available upon request), and the $\mathrm{K}_{\mathrm{d}}$ of PSMA-Glutamate Urea Lysine of $20 \mathrm{nM}$, these curves were generated using equations from Douglass et al. $^{2}$ As shown in the green trace, low concentration of low affinity Ab, yielded low ternary complex formation at any ARM concentration. With high affinity and concentration of $\mathrm{Ab}$ (orange trace), certain ARM concentrations can yield higher ternary complex formation followed by the formation of non-active binary complexes at excess ARM concentrations (autoinhibition). However, cARM-Ab-PSMA, becomes a binary complex as cARM-Ab is covalently linked and enables near maximal "ternary" complex formation.

\section{Expression of humanized anti-DNP IgG1 antibody (mmAb)}

The heavy and light chains of anti-DNP SPE7 antibody were cloned into the EcoRI/NheI sites of pFUSEss-CHIg-hG1(invivogen) and the EcoRI/BsiWI sites of pFUSEss-CLIg-hK (invivogen) respectively. The vectors were transfected at a 1:2 heavy chain to light chain ratio using the Expi293 Expression System Kit (ThermoFisher A14635) according to manufacturer's protocols. Supernatant was collected when the Expi293 cells reached $60 \%$ viability. The antibodies were purified using $5 \mathrm{ml}$ polypropylene columns (Qiagen 34964) with Protein G Agarose (ThermoFisher 15920010), followed by protein concentration and buffer exchange using Amicon Ultra-15 Centrifugal Filter Units. 


\section{Binding affinity measurements using BLI and FP}

a.

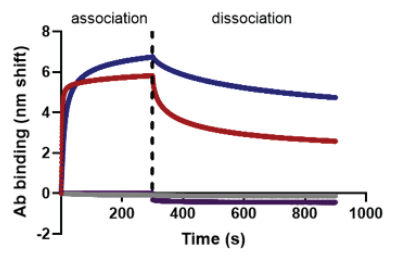

d.

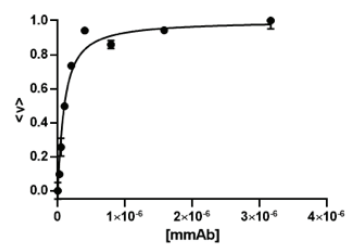

b.
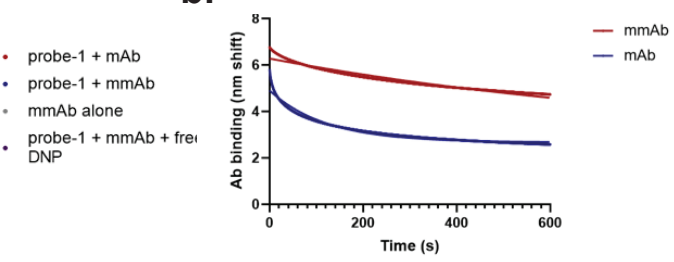

c.

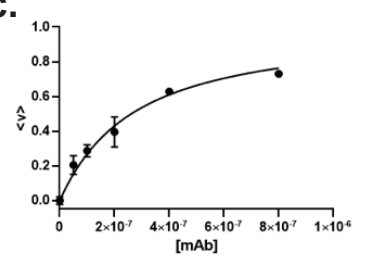

e.

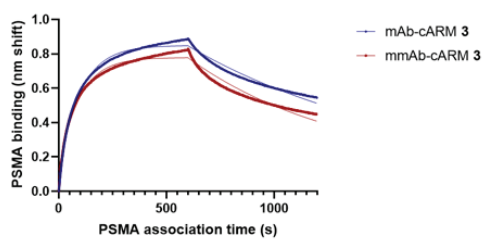

Figure S2. Measurement of binding affinities using BLI and FP a. mmAb and $\mathrm{mAb}$ DNP binding affinity and the dissociation rate constant $\left(k_{o f f}\right)$ was determined via BLI using probe immobilized Compound $\mathbf{1}$ (probe-1). b. Representative BLI dissociation sensogram fit using the 'one phase exponential decay' (on Graphpad Prism 8), to determine the binding affinity of anti-DNP Ab (500 nM Ab) for the DNP hapten. c. Fraction bound vs. [mAb] FP titration curve generated using Compound 2 and $\mathrm{mAb}$. d. Fraction bound vs. [mmAb] FP titration curve generated using Compound 2 and $m m A b$. The $K_{d}$ calculated for $m A b$ was $236.0 \mathrm{nM}+/-44 \mathrm{nM}$. The estimated $\mathrm{K}_{d}$ calculated for $\mathrm{mmAb}$ was $73.29 \mathrm{nM}+/-19 \mathrm{nM}$. The appearance of a square binding isotherm for titrations using $\mathrm{mmAb}$, suggests saturation binding conditions which introduce curve fitting errors. As such, the fitted value represents an upper limit for the true dissociation constant. e. PSMA binding affinity to the glutamate urea derived TBD of cARM $3\left(K_{d}\right)$ was determined with BLI pro$\mathrm{G}$ probes loaded with either mAb-cARM 3 or mmAb-cARM 3 complex

\begin{tabular}{|l|l|l|l|}
\hline Complex on Probe & $\mathrm{k}_{\text {on }}\left(\mathrm{M}^{-1} \mathrm{~s}^{-1}\right)$ & $\mathrm{k}_{\text {off }}\left(\mathrm{s}^{-1}\right)$ & $\mathrm{K}_{\mathrm{d}}(\mathrm{nM})$ \\
\hline mAb-cARM 3 & $17700 \pm 800$ & $0.0009 \pm 0.0001$ & $51 \pm 4$ \\
\hline mmAb-cARM 3 & $18800 \pm 500$ & $0.0015 \pm 0.0001$ & $78 \pm 4$ \\
\hline
\end{tabular}

Table S1. Binding constants describing the PSMA interaction with glutamate urea derived TBD of cARM 3.

\section{$\underline{B L I}$ assays to determine the binding affinity of $\mathrm{mmAb}$ and $\mathrm{mAb}$}

The experiment was conducted using an Octet Red 96 (ForteBio) with the temperature set at $25^{\circ} \mathrm{C}$, the RPM set at 1000 and the acquisition rate set at $5 \mathrm{~Hz}$. A volume of $250 \mu \mathrm{L}$ of each solution was loaded into a black flat-bottom 96-well plate (Grenier). Streptavidin probes from Fortebio were placed in 1X Kinetics Buffer (Fortebio) for 20 minutes prior to experiment for wetting. The experiment begins by placing the streptavidin probes in $1 \mathrm{X}$ Kinetics Buffer for three minutes to establish a baseline. Compound $\mathbf{1}$ was then loaded onto the probes by placing the probes in a $500 \mathrm{nM}$ Compound $\mathbf{1}$ solution for three minutes. Next, 
the probes were placed in a 5\% w/v milk quench (Nestle Carnation Instant Skim Milk Powder) solution in order to block any free or non-specific binding sites on the probe surface. The probes were placed in $1 \mathrm{X}$ Kinetics Buffer for 30 seconds in order to re-establish a baseline. Association of the antibody to Compound 1 was measured by placing the probe immobilized with Compound 1(probe-1) into a solution containing $1 \mu \mathrm{M}$ of either mAb (ACRObiosystems cat. \# DNP-M2) or mmAb for 5 minutes. Dissociation of antibody from Compound 1 was measured by placing the probe in $1 \mathrm{X}$ Kinetics Buffer for 10 minutes. The experiment was repeated twice, using $500 \mathrm{nM}$ and $250 \mathrm{nM}$ of antibody, for a total of three replicates.

A control where no Compound $\mathbf{1}$ was loaded onto the probe was conducted by placing the Streptavidin probe into a solution of $1 \mathrm{X}$ Kinetics Buffer instead of a solution of $500 \mathrm{nM}$ Compound 1 during the loading step. A free DNP competitor control was also conducted where $5 \mathrm{mM}$ DNP-glycine is added to the antibody solution and acts as a competitor to prevent Compound $\mathbf{1}$ from binding to the antibody.

The raw nm shift signal for the association and dissociation step obtained by the Octet Red96 was first baselined to the beginning of the association step ( $\mathrm{t}=0$ seconds) by subtracting the association signal at $\mathrm{t}=0$ seconds from the measured signal at each time point. The amplitude of the dissociation curve of all three replicates for both $\mathrm{mmAb}$ and $\mathrm{mAb}$ was set to the same total amplitude of $2.7 \mathrm{~nm}$ shift. This value was chosen by constraining the amplitude of each curve to a global shared value and letting GraphPad Prism calculate the shared total amplitude. $k_{\text {off }}$ was extracted from the dissociation phase of the binding curve using the 'one-phase exponential decay' model in GraphPad Prism 8. The

$$
\text { Ab binding }=\left((\text { Ab binding })_{0}-N S\right) X e^{-k_{\text {off }} X \text { time }}+N S
$$

where time was in seconds, $\mathrm{Ab}$ binding signal was in $\mathrm{nm}$ shift values, and $k_{\text {off }}$ was in $\mathrm{s}^{-1} \cdot \mathrm{k}_{\text {off }}$ was constrained to greater than zero. NS represents the non-specific binding and is fit by GraphPad Prism using the binding signal measured at the highest time points. The average $k_{\text {off }}$ from all three trials was calculated and reported; the error calculated is standard deviation.

$K_{d}$ was determined using the equation $\mathrm{K}_{\mathrm{d}}=\mathrm{k}_{\text {off }} / \mathrm{k}_{\text {on }}$. The $k_{\text {off }}$ values used represent the triplicate averages determined from BLI assays described above. The $k_{\text {on }}$ value used was $2 \times 10^{4} \mathrm{M}^{-1} \mathrm{~s}^{-1}$, which was previously estimated to describe the association of $\mathrm{IgG}$ antibodies with immobilized small molecule haptensthe association of IgG antibodies with immobilized small molecule haptens.

Fluorescence Polarization Assays to Determine ARM $K_{d}$ for mmAb and $\mathrm{mAb}$

General: All fluorescence polarization measurements were done on a TECAN SPARK plate reader, using Griener $^{\circledR}$ Black 96 Well plates. The FP was set to $40 \mathrm{mP}$ using the $50 \mathrm{nM}$ Compound 2 only control, which was used to calculate the G-Factor. The gain was optimized at $80 \%$ max RFU with Compound 2 incubated with the highest $\mathrm{Ab}$ concentration (3163 nM for mmAb and $800 \mathrm{nM}$ for mAb). A Z-position of 20000 was used. The buffer used was $1 \%$ DMSO $0.01 \%$ BSA (m/v), and $0.002 \%$ Tween 20 , in PBS.

Binding isotherms were generated by titrating increasing $\mathrm{mmAb}$ or $\mathrm{mAb}$ concentrations $(50-3163 \mathrm{nM}$, and 50-800 $\mathrm{nM}$ respectively) against fixed $50 \mathrm{nM}$ Compound 2 (Ltot). Binding isotherms were analyzed via 
non-linear curve fitting to equation 1 (derived below) to extract $\mathrm{K}_{\mathrm{d}}$. To generate binding isotherms FP signal was converted to "fraction bound" by first baselining FP signals to zero, and dividing these values by the highest FP value determined for mmAb.

\section{Equation 1.}

$$
\begin{aligned}
& \text { Let } \mathrm{L}_{\text {tor }}=[\text { Compound 2] }]_{\text {tot }} \mathrm{X}=[\mathrm{Ab}]_{\text {tot, }} \text { and } \mathrm{Y}=\langle\mathrm{v}\rangle
\end{aligned}
$$

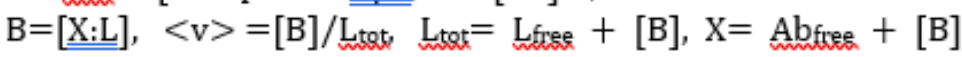

$$
\begin{aligned}
& ([\text { Lfree }] *[\text { Abfree }]) / B=\mathrm{Kd} \\
& (\text { Lfree } *[\mathrm{X}-\mathrm{B}]) / \mathrm{B}=\mathrm{Kd} \\
& ([\text { Ltot }-\mathrm{B}] *[\mathrm{X}-\mathrm{B}]) / \mathrm{B}=\mathrm{Kd} \\
& ([\text { Ltot } * \mathrm{X}]-\mathrm{B} * \mathrm{X}-\mathrm{B} * \text { Ltot }+\mathrm{B} 2) / \mathrm{B}=\mathrm{Kd} \\
& ([\text { Ltot } * X] / B)-X-\text { Ltot }+B=K d \\
& ([\text { Ltot } * X] / B)=K d+X+\text { Ltot }-\mathrm{B} \\
& \lceil\text { Ltot } * \mathrm{X}\rceil=\mathrm{Kd} * \mathrm{~B}+\mathrm{X}+\text { Ltot }-\mathrm{B} 2 \\
& 0=-\mathrm{B} 2+\mathrm{Kd} * \mathrm{~B}+\mathrm{X} * \mathrm{~B}+\text { Ltot } * \mathrm{~B}-[\text { Ltot } * \mathrm{X}] \\
& 0=\mathrm{B}^{2}-\mathrm{XB}-\mathrm{KdB}-\operatorname{Ltot} \mathrm{B}+[\text { Ltot } * \mathrm{X}] \\
& \mathrm{B}=\frac{\left(\left((\mathrm{Kd}+\text { Ltot }+\mathrm{X})-\sqrt{\left.\left.\left.\left((-\mathrm{Kd}-\text { Ltot }-\mathrm{X})^{2}-4 * \text { Ltot } * \mathrm{X}\right)\right)\right)\right)}\right.\right.}{2} \\
& <\mathrm{v}>=\frac{\left(\left((\mathrm{Kd}+\text { Ltot }+\mathrm{X})-\sqrt{\left.\left.\left.\left((-\mathrm{Kd}-\text { Ltot }-\mathrm{X})^{2}-4 * \text { Ltot } * \mathrm{X}\right)\right)\right)\right)}\right.\right.}{2 * \text { Ltot }} \\
& <\mathrm{v}>=\frac{\left(\left((\mathrm{Kd}+\text { Ltot }+\mathrm{X})-\sqrt{\left.\left.\left.\left((-\mathrm{Kd}-\text { Ltot }-\mathrm{X})^{2}-4 * \text { Ltot } * \mathrm{X}\right)\right)\right)\right)}\right.\right.}{2 * \text { Ltot }}
\end{aligned}
$$

The final equation was input into GraphPad Prism to calculate the Kd

Determining PSMA binding affinity to the glutamate urea derived TBD of cARM 3

cARM $3(500 \mathrm{nM})$ and $75 \mathrm{nM}$ of either mmAb or mAb (AcroBiosystems Catalog \# DNP-M2) was reacted in $1 \mathrm{X}$ Kinetics Buffer (ForteBio) for at room temperature four hours prior to the experiment. IgG Fc capture (ProG) probes from ForteBio were placed in 1X Kinetics Buffer for 20 minutes prior to the experiment for wetting. The experiment was conducted using an Octet Red96 (ForteBio), where the acquisition rate was set to $5 \mathrm{~Hz}$ and 
the temperature was held at $25^{\circ} \mathrm{C}$. The plate shaker setting was $1000 \mathrm{RPM}$. A volume of $250 \mu \mathrm{L}$ of each solution was loaded onto a black flat-bottom 96-well plate (Grenier). The experiment began by placing the ProG probes in 1X Kinetics Buffer for four minutes to establish a baseline. Next, the probes were placed into the cARM 3 and anti-DNP antibody reaction mixture to load the covalent complex (cARM$\mathrm{Ab}$ ) onto the probe. Next, the probes were placed in a solution of $5 \mathrm{mM}$ DNP-glycine competitor in $1 \mathrm{X}$ Kinetics Buffer in order to disrupt any non-covalent or non-specific binding. The baseline was reestablished by then placing the probes in $1 \mathrm{X}$ Kinetics Buffer for 0.5 minutes. To measure PSMA association, the probes were placed in a solution of $500 \mathrm{nM}$ human PSMA protein in 1X Kinetics Buffer for 10 minutes. Human PSMA protein was generously provided by Dr. Cyril Barinka (Institute of Biotechnology CAS, Czech Republic)The probes were then placed in 1X Kinetics Buffer for 10 minutes to measure dissociation.

The raw nm shift signal for the association and dissociation step obtained by the Octet Red96 was first baselined to the beginning of the association step ( $\mathrm{t}=0$ seconds) by subtracting the association signal at $\mathrm{t}=0$ seconds from the measured signal at each time point. The $K_{d}$ was determined by fitting both the association and dissociation curves using the 'association then dissociation' binding model in GraphPad Prism 8. The experiment was repeated once for a total of two replicates.

\section{Determination of the second order rate constant describing solution covalent labeling kinetics $\boldsymbol{k}_{\underline{\text { inact }}} / \boldsymbol{K}_{I}$.}

The specific labelling of an antibody by a cARM occurs via a two-step mechanism. In the first step, the cARM binds to the antibody via its $\mathrm{ABD}$ and forms a reversible complex. $K_{I}$ can represent the binding affinity of this first step and describes the concentration of cARM required to achieve half of the maximal rate of covalent labeling. ${ }^{3}$ Under certain conditions, $K_{I}$ is equal to the dissociation constant $K_{d}$. In the second step, the covalent bond is formed as the ALD domain of the cARM reacts with the antibody. The first order rate constant $k_{\text {inact }}$ represents the maximal rate of this covalent bond formation. ${ }^{3}$ By taking both of these constants into account, the rate of covalent bond formation as a function of free cARM can be described by the saturation kinetics second order rate constant $k_{\text {inac }} / K_{I}$ or the ratio of $k_{\text {inact }}$ to $K_{I .}{ }^{3}$ This second order rate constant was determined by monitoring covalent product (cARM-Ab) formation as a function of time via BLI using ProG IgG Fc capture probes. Note: a nonspecific labeling reaction occurs independent of binding to the DNP binding site with any biological nucleophile, and follows second order kinetics without saturation. 
a.

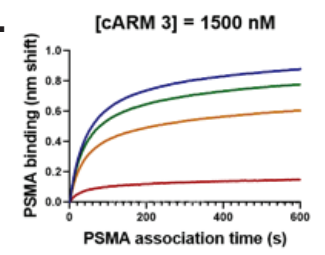

[CARM 3] $=500 \mathrm{nM}$

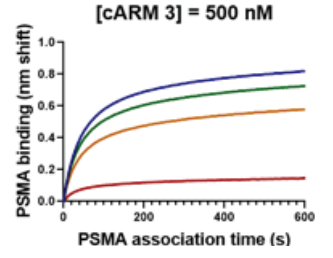
[CARM 3] = $75 \mathrm{nM}$

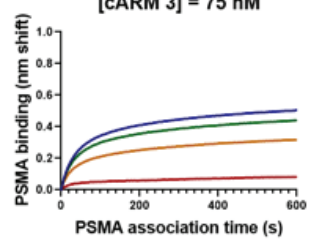

[CARM 3] $=1000 \mathrm{nM}$

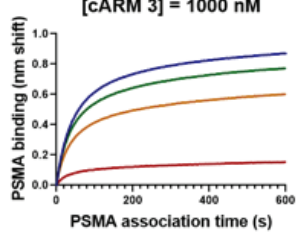

[CARM 3] $=250 \mathrm{nM}$

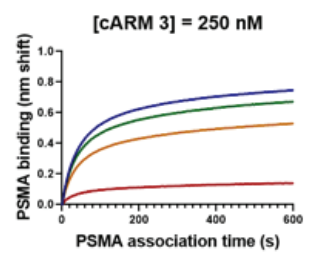

- $\mathrm{t}=8 \mathrm{hr}$

- $\mathrm{t}=4 \mathrm{hr}$

- $\mathrm{t}=2 \mathrm{hr}$

- $t=1 \mathrm{hr}$

- $\mathrm{t}=0 \mathrm{hr}$

- $\mathrm{t}=8 \mathrm{hr}+\mathrm{ARM} 4+\mathrm{mmAb}$ b.
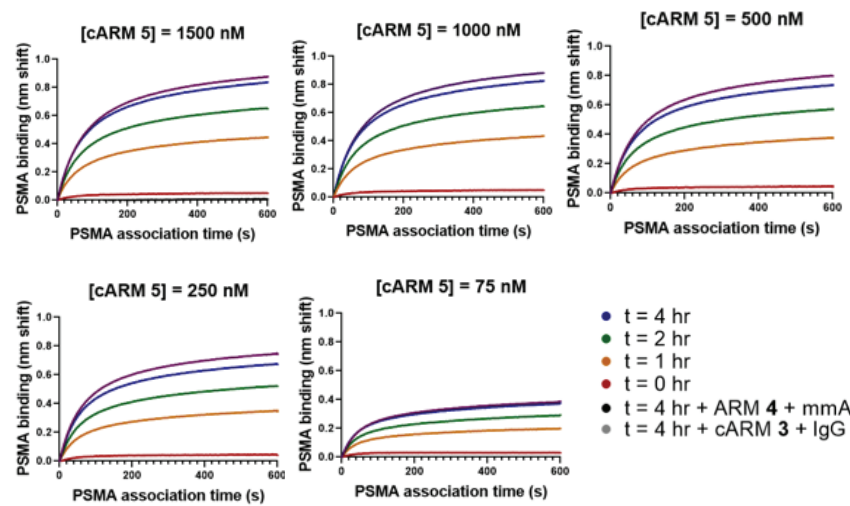

- $\mathrm{t}=4 \mathrm{hr}$

- $\mathrm{t}=2 \mathrm{hr}$

$-\mathrm{t}=1 \mathrm{hr}$
$\mathrm{t}=0 \mathrm{hr}$

- $\mathrm{t}=4 \mathrm{hr}+\mathrm{ARM} 4+\operatorname{mmAb}$
$-\mathrm{t}=4 \mathrm{hr}+\mathrm{CARM} 3+\operatorname{lgG}$

C.

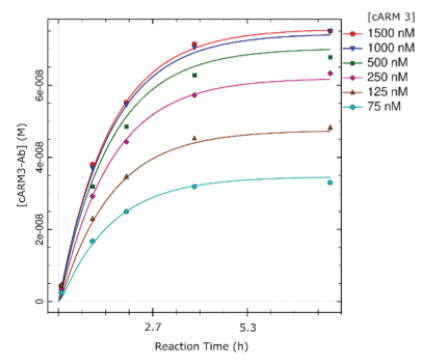

Figure S3. Determination of the second order rate constant describing solution covalent labeling kinetics $\mathrm{k}_{\text {inat }} / \mathrm{K}_{\mathrm{I}}$. a. Plots of increasing PSMA binding with time (proportional to cARM-Ab formation) for the reaction of anti-DNP mmAb $(75 \mathrm{nM})$ with various concentrations of cARM 3. The fractional conversion of product at each time point and CARM 3 concentration, taken from the PSMA binding amplitude of these plots can be used to determine the second order rate constant $k_{\text {inac }} / K_{I}$. b. Plots of increasing PSMA binding with time (proportional to cARM-Ab formation) for the reaction of anti-DNP mmAb (75 $\mathrm{nM})$ with various concentrations of cARM 5. c. A plot of increasing PSMA binding amplitude with time, from the plots in $b$, proportional to the extent of cARM 5-Ab formation, was fit by numerical integration methods using Dynafit software to extract kinetic constants

Table S2. rate constants for covalent reaction of anti-DNP mmAb with cARM 5

\begin{tabular}{|l|l|}
\hline $\mathbf{k}_{\text {inact }}$ & $0.000184 \mathrm{~s}^{-1}$ \\
\hline $\mathbf{K}_{\mathbf{I}}$ & $49.1 \mathrm{nM}$ \\
\hline $\mathbf{K}_{\text {inact }} / \mathbf{K}_{\mathbf{I}}$ & $3750\left(\mathrm{M}^{-1} \mathrm{~s}^{-1}\right)$ \\
\hline
\end{tabular}

The experiment was conducted using an Octet Red96 (ForteBio) where the acquisition rate was set to $5 \mathrm{~Hz}$ and the temperature was held at $25^{\circ} \mathrm{C}$. The plate shaker setting was $1000 \mathrm{RPM}$. A volume of $250 \mu \mathrm{L}$ of 
each solution was loaded into a black flat-bottom 96-well plate (Grenier). IgG Fc capture (ProG) probes from ForteBio were placed in 1X Kinetics Buffer (ForteBio) for 20 minutes prior to the experiment for wetting. The experiment begins by placing the ProG probes in 1X Kinetics Buffer for four minutes to establish a baseline. The probes were then placed in a solution of $75 \mathrm{nM} \mathrm{mmAb}$ or mAb (Acro Biosystems Catalog \# DNP-M2) and varying concentrations (75 nM, $125 \mathrm{nM}, 250 \mathrm{nM}, 500 \mathrm{nM}, 1000 \mathrm{nM}$, or 1500 $\mathrm{nM}$ ) of cARM 3 in 1X Kinetics Buffer. For the initial zero-hour time point reading, the antibody was added to the cARM solution immediately before the plate was placed into the Octet Red96 to minimize cARM 3 reaction with the antibody. Next, the probes were placed in a solution of $5 \mathrm{mM}$ DNP-glycine competitor in $1 \mathrm{X}$ Kinetics Buffer in order to disrupt any non-covalent binding. The DNPglycine will outcompete any non-covalently bound cARM 3 with anti-DNP antibody. The synthesis of DNP-glycine is outlined in Scheme S1 of reference 1. The baseline was then re-established by placing the probes in $1 \mathrm{X}$ Kinetics Buffer for 0.5 minutes. To measure PSMA association, the probes were placed in a solution of $500 \mathrm{nM}$ human PSMA protein in $1 \mathrm{X}$ Kinetics Buffer for 10 minutes. Human PSMA protein was generously provided by Dr. Cyril Barinka (Institute of Biotechnology CAS, Czech Republic). Data collection was repeated using the exact same sample plate prepared previously 0.5 , one, two, and four hours after addition of the antibody to the reaction mixture. The entire assay was performed in duplicate for each antibody. The BLI assay described above was also used to determine the second-order rate constant describing the solution labelling kinetics of cARM 5 and mmAb. The procedure was done as described above except that an 8-hour reaction time point measurement was also included.

Control experiments included a) a repetition where $1500 \mathrm{nM}$ ARM 4 was incubated with the antiDNP antibody instead of cARM 3, and b) a repetition where $75 \mathrm{nM}$ of non-DNP binding human IgG (Jackson ImmunoResearch Catalog \#009-000-003) was used instead of mmAb or mAb. The raw nm shift signal for the association and dissociation step obtained by the Octet Red96 was first baselined to the beginning of the association step ( $\mathrm{t}=0$ seconds) by subtracting the association signal at $\mathrm{t}=0$ seconds from the measured signal at each time point. The fractional conversion to product (cARM-Ab) was calculated in Excel by setting the maximum PSMA binding signal observed for the highest cARM 3 concentration $(1500 \mathrm{nM})$ at 4 hours to equal $100 \%$ reaction. This was assumed to be reaction completion as there was very little increase in product signal, and therefore very little reaction occurring, when cARM 3 and the anti-DNP antibody was allowed to react for longer. This is illustrated by the $\mathrm{t}=8 \mathrm{~h}$ condition in Figure $3 \mathrm{~A}$ in the main manuscript. Note: longer time points lead to observed rates obscured by CARM 3 hydrolysis. The following equation was used to calculate fractional product conversion: ( $\mathrm{nm}$ shift amplitude)/ ( $\mathrm{nm}$ shift amplitude at $1500 \mathrm{nM}$ cARM, $t=$ 4h). A sample calculation for the fractional product conversion when the reaction time is two hours and the cARM 3 concentration is $500 \mathrm{nM}$ is shown below:

fractional product conversion $=(\mathrm{nm}$ shift amplitude at $500 \mathrm{nM}$ cARM, $\mathrm{t}=2 \mathrm{hrs}) /(\mathrm{nm}$ shift amplitude at $1500 \mathrm{nM} \mathrm{cARM}, \mathrm{t}$ $=4 \mathrm{~h})$

fractional product conversion $=0.729579 / 0.887147$

fractional product conversion $=0.882388$

The fractional conversion to product values were multiplied by the concentration of antibody ( $75 \mathrm{nM})$ to determine the cARM3-Ab covalent product concentration. A curve of covalent product (cARM3$\mathrm{Ab}$ ) concentration over time was fit using Dynafit to determine reaction kinetics constants through nonlinear least-squares regression analysis. The average rate constants from both trials were calculated and reported 
in Table 1 of the main manuscript. The Dyanfit ${ }^{4}$ script used to extract the second order rate constants from the curve using a differential-evolution model is as follows:

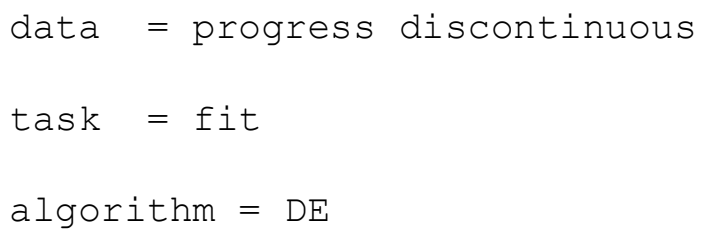


monitor $\mathrm{P}$

file fl | concentration CARM $=1500 e-9 \mid$ label $=1500 \mathrm{nM}$ cARM3

file f2 | concentration CARM $=1000 e-9 \mid$ label $=1000 \mathrm{nM}$ CARM3

file f3 | concentration $\mathrm{CARM}=500 \mathrm{e}-9 \mid$ label $=500 \mathrm{nM}$ cARM3

file $f 4 \mid$ concentration $\mathrm{cARM}=250 \mathrm{e}-9 \quad \mid$ label $=250 \mathrm{nM}$ cARM3

file f5 | concentration $\mathrm{CARM}=125 \mathrm{e}-9 \quad \mid$ label $=125 \mathrm{nM}$ CARM3

file f6 | concentration cARM $=75 e-9 \quad \mid$ label $=75$ nM cARM3

[output]

directory ./kinetics/monoclonalAbExpl/output_2ndtry

[settings]

$\{$ Output\}

XAxisLabel $=$ Time $(\mathrm{s})$

YAxisLabel $=[\mathrm{CARM}-\mathrm{Ab}](\mathrm{M})$

[end]

The first section of the Dynafit script denotes that the type of data that was input into the software was discontinuous measurements of the progress of a reaction (data = progress discontinuous) as well as that the data should be fit using the 'Differential-Evolution' algorithm (algorithm $=\mathrm{DE}$ ). The 'Differential-Evolution' algorithm is used for least squares data fitting and finds the global optima using an evolutionary strategy computational approach. ${ }^{5}$

The two-step mechanism of covalent cARM labelling of specific antibodies is outlined under the Mechanism section of the script. The first line (Ab $+C A R M<===>A b . C A R M \quad: k 1 \quad k 2$ ) outlines the first step when cARM binds to the antibody to form a reversible complex, where $k_{l}$ represents the $k_{o n}$ and $k_{2}$ represents the $k_{\text {off }}$ of this binding step. $K_{I}$ is calculated from the equation $\mathrm{K}_{\mathrm{I}}=\mathrm{k}_{2} / \mathrm{k}_{1}$. The second line ( Ab.CARM ----> P : kinact) represents the second step when the covalent bond is formed, where $k_{\text {inact }}$ represents the rate of covalent bond formation. The last line (CARM ----> 
CARMb : kbroken) takes into account cARM hydrolyzing into cARM $\mathrm{b}_{\mathrm{b}}$, which is unable to label antibodies. $k_{\text {broken }}$ represents the rate of hydrolysis.

The Constants section of the script denotes all the constants that the software needs to derive as well as initial estimated values and constraint ranges for each constant that help Dynafit with fitting the data. The line $\mathrm{P}=1$ ? $(0.95 \ldots 1.05)$ describes that $1 \mathrm{nM}$ of antibody and cARM that has reacted results in approximately $1 \mathrm{nM}$ of product (cARM-Ab) measured in the assay.

\section{Luminescence-Based Antibody Dependent Cellular Cytotoxicity (ADCC) Quantification}

General: ADCC was quantified using the ADCC Reportor Bioassay kit (Promega G7010). All ADCC induced luminescence was measured on a SpectraMax i3 plate reader (Molecular Devices). The human IgG isotype control used was purchased from Jackson ImmunoResearch (009-000-003). The human IgG1 monoclonal anti-DNP antibody (mAb) was purchased from acrobiosystems (DNP-M2). The humanized anti-DNP IgG1 antibody (mmAb) was expressed as per protocol above. Human IgG from serum was purchased from Innovative Research (IHUIGGAP1000MG). Anti-DNP depleted serum was made from

human IgG from serum (Innovative Research) as per protocol below. For PSMA competition controls, 2PMPA was purchased from Sigma (SML1612). Hek-293T (PSMA+/-) cell lines were generously given by Dr. Cyril Barinka (Institute of Biotechnology CAS, Czech Republic). Ultra low IgG FBS was purchased

a.

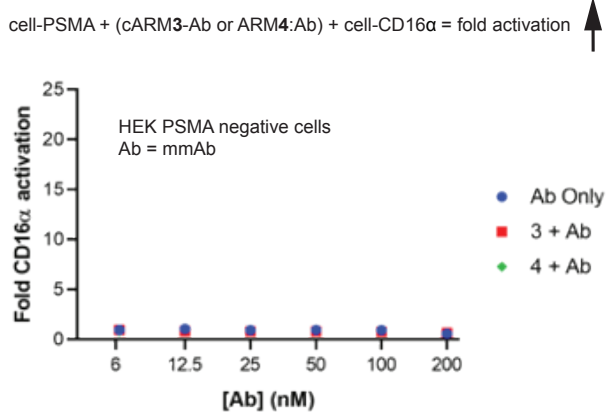

C.

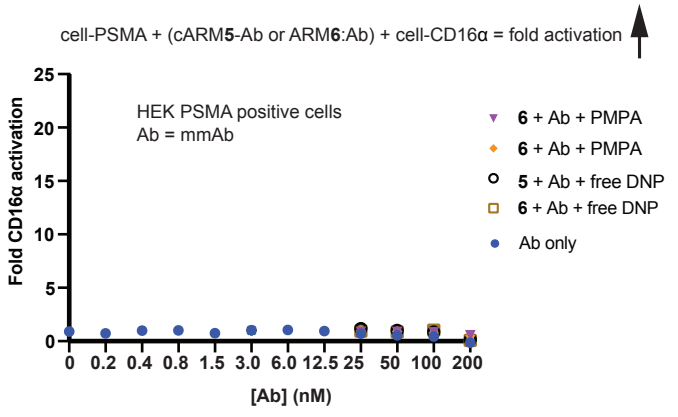

b. cell-PSMA + (CARM3-Ab or ARM4:Ab) + cell-CD16a = fold activation

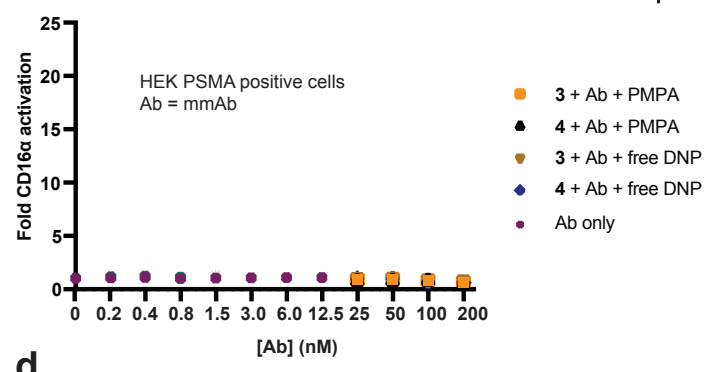

d.

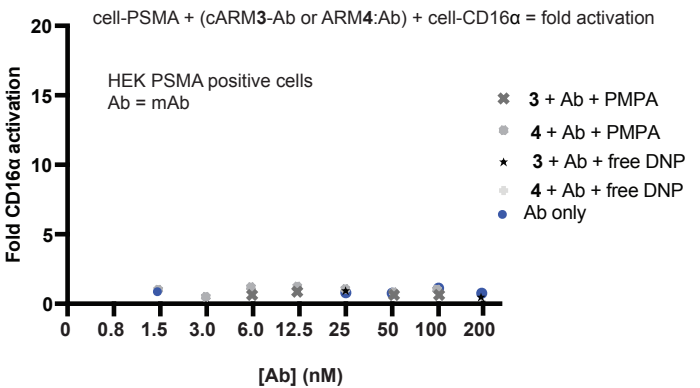

Figure S4. Supporting ADCC data for main manuscript Figure 3 and Figure 4. a. ADCC target selectivity with cARM3 and ARM4 with PSMA negative isogenic HEK cell line, Figure 3C (main text). Comparison of cARM3/ARM4 mediated immune receptor activation with mmAb on PSMA negative isogenic HEK cells, was determined using a Promega ADCC bioassay at $37^{\circ} \mathrm{C}$. Experiment completed as described below. b. Additional controls to supplement Figure 3C (main text).c. Additional controls to supplement Figure 3e (Main text). d. Additional controls to supplement Figure 4C (main text). 
from Fischer Scientific (A3381901). RPMI-1640 was purchased as a powder from Fischer Scientific (31800089) and resuspended. DMEM was purchased as a powder from Fischer Scientific (12800082) and resuspended. Pen/Strep was purchased from Fischer Scientific (15140-122). FBS was purchased from Fischer Scientific (12484-028). Zeocin was purchased from Fischer Scientific (R25001). HEK-PSMA cells were cultured in DMEM media with $2 \mathrm{mM}$ L-glut, 1\% Pen/Strep, 10\% FBS, 50ug/mL Zeocin. HEK cells were cultured in DMEM media with 2mM L-glut, 1\% Pen/Strep, 10\% FBS.

Evaluation of cARM3/5 and ARM4/6 modulation of immune cell receptor (CD16) activation via covalent antibody recruitment in promega ADCC bioassays (Figure 3. C/E, Figure 4. C, Figure 6. C/D)

Preparation of antibody-cARM/:ARM stocks were mixed overnight prior to addition to the ADCC plate. In the case of $\mathrm{mmAb}$ and $\mathrm{mAb}$, incubation was carried out at $600 \mathrm{nM}$ antibody and 1.2uM cARM3 or ARM4. In the case of IgG from serum, incubation was completed at 230uM antibody and 8.7uM cARM3 or ARM4. In all cases, DMSO was kept close to $1 \%$. After the overnight incubation, a dilution series was completed on the antibody-cARM/:ARM stocks in RPMI (1\% DMSO). These conditions were used as described below.

Target cells were seeded at a density of $2.5 \times 10^{4}$ cells per well in opaque 96 well flat-bottom plates (Corning Costar, 3917) in complete media. Sixteen hours after seeding, cells were washed gently with 100uL of neat RPMI. To the cells, $25 \mathrm{uL}$ of RPMI supplemented with $4 \%$ ultra-low IgG FBS was added followed by $25 \mathrm{uL}$ of antibody +/- cARM/ARM conditions described above. After a 30-minute incubation, 25uL of supplemented RPMI containing 7.5 $\times 10^{4}$ Jurkat effector cells expressing human FcgRIIIa (CD16) were added to each well. The plates were then incubated for 6 additional hours. 75ul of Bio-Glo Luciferase Assay Reagent was added to each well, and luminescence was quantified using the SpectraMax i3 plate reader.

\section{Antibody Dependent Cellular Phagocytosis (ADCP) evaluation of cARM3/5 and ARM4/6}

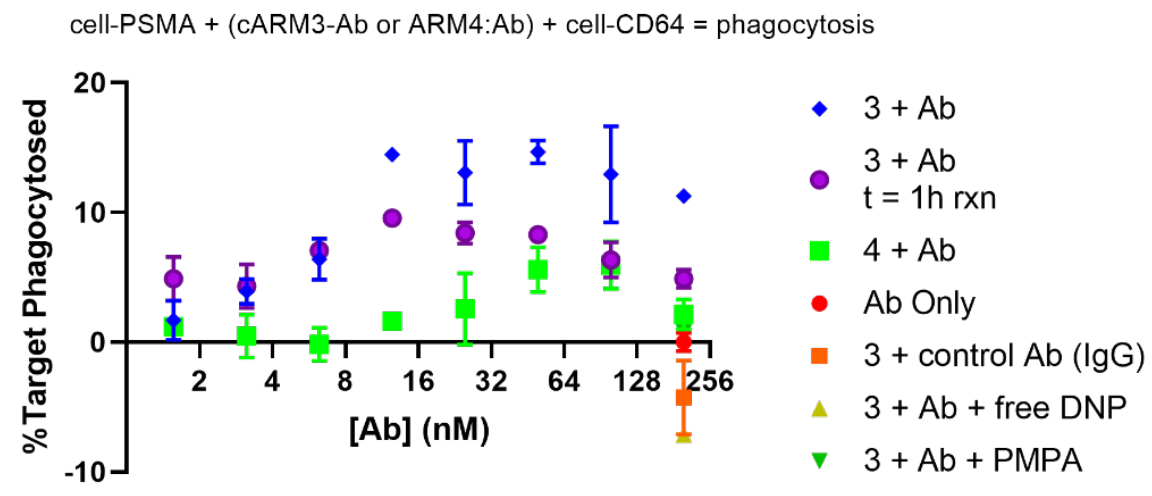

Figure S5. cARM3/ARM4 induced ADCP with mmAb on LNCaP target cells. Comparison of cARM3 and ARM4 mediated immune receptor complex formation with mmAb on PSMA+ LNCaP cells, was determined using a flow cytometry-based ADCP assay. Experiment completed as described below. 
General: All flow cytometry experiments were run on a BD LSRII Flow Cytometer. The human IgG isotype control used was purchased from Jackson ImmunoResearch (009-000-003). The human IgG1 monoclonal anti-DNP antibody (mAb) was purchased from acrobiosystems (DNP-M2). The humanized anti-DNP IgG1 antibody (mmAb) was expressed as per protocol below. PSMA expression was confirmed with an anti-PSMA antibody alexa 647 conjugate (Novus Biologicals, Catalog \#FAB4234R). For PSMA competition controls, PMPA was purchased from Sigma (SML1612). Hek-293T (PSMA+/-) cell lines were generously given by Dr. Cyril Barinka (Institute of Biotechnology CAS, Czech Republic). U937 cells were generously given by Dr. John Valliant (McMaster University, Canada). LNCaP cells were generously given by Dr. Karen Mossman (McMaster University, Canada). IFN- $\gamma$ was purchased from Fischer Scientific (PHC4031). Ultra low IgG FBS was purchased from Fischer Scientific (A3381901). RPMI-1640 was purchased as a powder from Fischer Scientific (31800089) and resuspended. DMEM was purchased as a powder from Fischer Scientific (12800082) and resuspended. DiD cell dye was purchased from Fischer Scientific (V22887). DiO cell dye was purchased from Fischer Scientific (V22886). TrypLE Express was purchased from Fischer Scientific (12604013). 96-Well U-bottom plates were purchased from FischerScientific (08-772-17). Pen/Strep was purchased from Fischer Scientific (15140-122). FBS was purchased from Fischer Scientific (12484-028). Zeocin was purchased from Fischer Scientific (R25001). HEK-PSMA cells were cultured in DMEM media with $2 \mathrm{mM}$ L-glut, 1\% Pen/Strep, $10 \% \mathrm{FBS}, 50 \mathrm{ug} / \mathrm{mL}$ Zeocin. HEK cells were cultured in DMEM media with 2mM L-glut, 1\% Pen/Strep, 10\% FBS. LNCaP cells were cultured in RPMI media with 1\% Sodium Pyruvate, 1\% Pen/Strep, 10\% FBS. U937 monocytes were cultured in RPMI media with 2mM L-Glut, 1\% Pen/Strep, 10\% FBS.

\section{Evaluation of ADCP in flow cytometry assays}

For preparation of effector monocytes, 24 hours prior to inducing phagocytosis U937 monocytes were seeded at 500,000 cells $/ \mathrm{mL}$ and activated with IFN- $\gamma(0.1 \mathrm{mg} / \mathrm{mL})$. After incubation, these cells were then counted and washed twice with serum free assay media (neat RPMI). Cells were then suspended to a concentration of 1 million cells $/ \mathrm{mL}$ and stained with 1.9uM Vybrant DiD Cell-Labelling Solution for 30 minutes $\left(37^{\circ} \mathrm{C}, 5 \% \mathrm{CO}_{2}\right)$. Cells were then washed $3 \mathrm{x}$ with warm assay media (AM, 14\% Ultra Low $\operatorname{IgG}$ FBS in RPMI) and resuspended to a concentration of $3.0 \times 10^{6}$ million cells $/ \mathrm{mL}$ to be plated for use in assay (50uL holds 150,000 cells).

Prior to overnight incubation, antibody-cARM/:ARM experimental and control conditions were prepared. For each antibody condition, antibody-cARM/:ARM were incubated together at a ratio of $2: 1$ (cARM/ARM:Ab) and at a concentration of $4 \mathrm{x}$ the top antibody concentration listed. If competitors are used, they are added to the antibody stock solution at a concentration of 5000x excess to cARM/ARM if competing for PSMA, and 10,000x excess if competing for anti-DNP antibody. After overnight incubation, a dilution series was conducted using each condition stock which was then equilibrated for 90 minutes prior to addition to the assay well plate as described below.

On the day of the experiment, target cells (90\% confluent in a T-150 flask) were suspended with TrypLE and quenched with complete growth media. These cells were then counted and washed twice with serum free assay media (neat RPMI). Cells were then suspended to a concentration of 1 million cells $/ \mathrm{mL}$ and stained with 5.7uM Vybrant DiO Cell-Labelling Solution for 30 minutes $\left(37^{\circ} \mathrm{C}, 5 \% \mathrm{CO}_{2}\right)$. Cells were then 
washed 3x with warm assay media (AM, 14\% Ultra Low IgG FBS in RPMI) and resuspended to a concentration of $6.0 \times 10^{6}$ million cells $/ \mathrm{mL}$ to be plated for use in assay ( $25 \mathrm{uL}$ holds 150,000 cells).

To a U-bottom 96-well plate, $25 \mathrm{uL}$ of target cells followed by $25 \mathrm{uL}$ of each antibody condition were added (for PSMA expressions check, 1.5uL anti-PSMA A647 antibody added with 25uL assay media). Next, $50 \mathrm{uL}$ of activated monocytes were added to these wells. The plate was centrifuged at $800 \mathrm{rpm}$ for 2 minutes to pellet cells and placed in a $37^{\circ} \mathrm{C} 5 \% \mathrm{CO}_{2}$ incubator for 1 hour. Plates were placed on ice and all conditions were then run on flow cytometry to determine ADCP. DiO stained cells were detected in the A488 channel, DiD stained cells were detected in the APC Cy7 channel, PSMA expression was confirmed with the Alexa 647 channel. The following voltages were used: FSC: 430, SSC: 290, A488: 260, APC Cy7: 410, A647: 490. ADCP was determined by plotting monocyte stain against bead stain, and was quantified as $\%$ Target Phagocytosed $=\left(\frac{\text { Double Positive Events }}{\text { Target Only Events }+ \text { Double Positive Events }}\right) * 100$. This was normalized to antibody only control.

\section{Evaluation of Covalent (cARM3) vs Non-Covalent (ARM 4) total Antibody Recruitment at 37 and 4} ${ }^{\circ} \mathrm{C}$

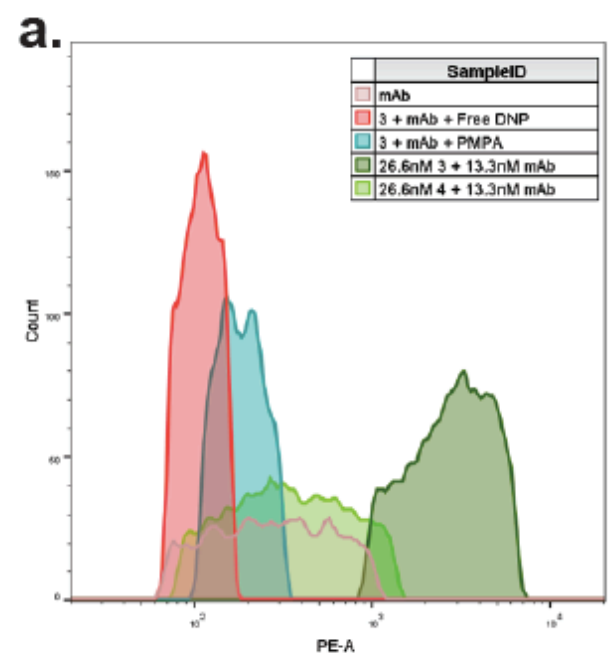

c.

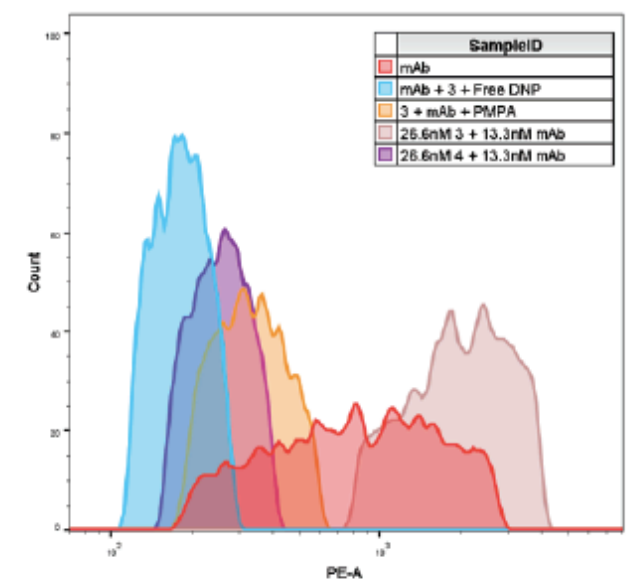

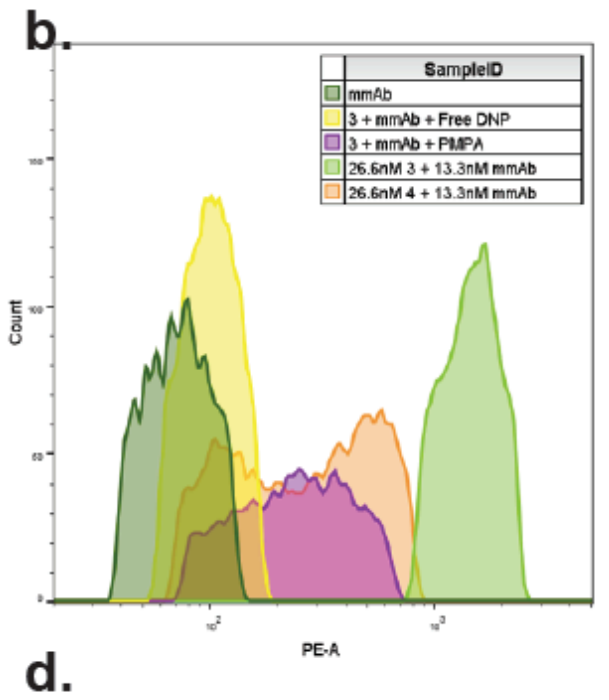

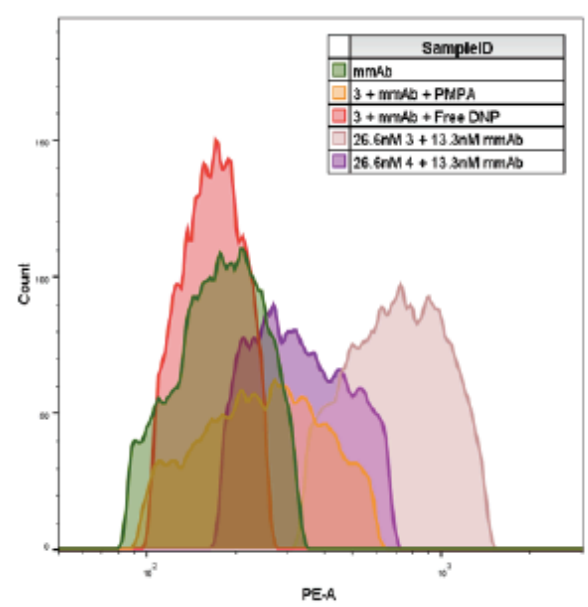


Figure S6. Evaluation of Covalent (cARM 3) vs non-covalent (ARM 4) total antibody recruitment to target cells. A) Flow cytometry histograms depicting cARM3/ARM4 mAb antibody recruitment to PSMA+ HEK target cells at $37^{\circ} \mathrm{C}$. B). Flow cytometry histograms depicting cARM3/ARM4 mmAb antibody recruitment to PSMA+ HEK target cells at $37^{\circ} \mathrm{C}$. C) Flow cytometry histograms depicting cARM3/ARM4 mAb antibody recruitment to PSMA+ HEK target cells at $4^{\circ} \mathrm{C}$. D Flow cytometry histograms depicting cARM3/ARM4 mmAb antibody recruitment to PSMA+ HEK target cells at $4^{\circ} \mathrm{C}$.

General: All flow cytometry experiments were run on a BD LSRII Flow Cytometer. The human IgG isotype control used was purchased from Jackson ImmunoResearch (009-000-003). The human IgG1 monoclonal anti-DNP antibody was purchased from acrobiosystems (DNP-M2). The humanized anti-DNP IgG1 antibody (MmAb) was expressed as per protocol below. PSMA expression was confirmed with an anti-PSMA antibody alexa 647 conjugate (Novus Biologicals, Catalog \#FAB4234R). For PSMA competition controls, PMPA was purchased from Sigma (SML1612). Hek-293T (PSMA+/-) cell lines were generously given by Dr. Cyril Barinka (Institute of Biotechnology CAS, Czech Republic). DMEM was purchased as a powder from Fischer Scientific (12800082) and resuspended. 96-Well U-bottom plates were purchased from FischerScientific (08-772-17). Pen/Strep was purchased from Fischer Scientific (15140122). FBS was purchased from Fischer Scientific (12484-028). Zeocin was purchased from Fischer Scientific (R25001). HEK-PSMA cells were cultured in DMEM media with 2mM L-glut, 1\% Pen/Strep, $10 \%$ FBS, 50ug/mL Zeocin.

640nM cARM3 or ARM4 was incubated with $320 \mathrm{nM}$ antibody (mmAb or mAb) at room temperature, overnight. After this incubation, these conditions were diluted down in a dilution series $(1: 2,1: 3,1: 3,1: 3)$ for use described below.

HEK293 cells transfected with PSMA, were washed 3x and placed in a flow buffer containing 4\% FBS, $0.5 \mathrm{mM}$ EDTA/EGTA, $0.1 \%$ Sodium Azide, at a concentration of $2 \mathrm{X} 10^{6} \mathrm{Cells} / \mathrm{mL}$. $75 \mathrm{uL}$ of cells were added (150 000 Cells per sample), and kept on ice. $25 \mathrm{uL}$ of antibody+cARM or antibody+ARM conditions prepared above were added to the target cells (experimental antibody concentrations: $80 \mathrm{nM}, 40 \mathrm{nM}$, 13.3nM, $4.4 \mathrm{nM}, 1.5 \mathrm{nM}$ ). For the DNP Control, $4.5 \mathrm{mM}$ was added to antibody for 5 minutes, then the cARM3/ARM4 was added, and the solution incubated overnight. For the 2-PMPA Control, 0.5mM was added to cells for 5 minutes, then the Ab/cARM3 solution and Ab/ARM4 solution was added. Afterwards $1 \mathrm{uL}$ of $0.5 \mathrm{mg} / \mathrm{mL}$ Goat anti-Human IgG Fc Secondary Antibody, PE, (Catalog \# 12-4998-82) was added to every condition, and mixed. At this point, $37^{\circ} \mathrm{C}$ conditions were incubated at 37 degrees celsius for 30 minutes, and 4 degree conditions were placed on ice for 30 minutes. Conditions were run in duplicate. PSMA loading/expression was confirmed with an anti-PSMA antibody alexa 647 conjugate (Novus Biologicals, Catalog \#FAB4234R). Voltages were FSC: 330, SSC: 270, Alexa 647: 490, PE: 320

Table S4. PSMA Check MFI for mmAb and mAb 37 Degrees Flow Ab Recruiting.

\begin{tabular}{|l|l|l|}
\hline & Replicate 1 - MFI A647 & Replicate 2 - MFI A647 \\
\hline mmAb 37 Degrees - PSMA Check & 11693 & 11146 \\
\hline mAb 37 Degrees - PSMA Check & 13204 & 12353 \\
\hline
\end{tabular}




\section{$\underline{\text { Serum Antibody Enrichment and Quantification }}$}

\section{Quantification of affinity column purified anti-DNP antibody}

Anti-DNP specific antibody was quantified using BLI. The concentration of anti-DNP antibody isolated in the affinity chromatography enriched sample was determined by looking at the binding of the isolated enriched antibody sample to Compound 1 loaded onto Streptavidin probes on the Octet Red96 (probe-1). The amplitude of anti-DNP antibody binding to probe-1 after 5 minutes of association was compared to a standard curve constructed using 5-100 nM of mmAb in PBS to calculate anti-DNP concentration. The equation of the standard curve is: $\mathrm{nm}$ shift amplitude $=0.04779$ ( $\mathrm{Ab}$ concentration in $n M)-0.1918$. This equation was derived using the 'simple linear regression' model in GraphPad Prism 8.

a.

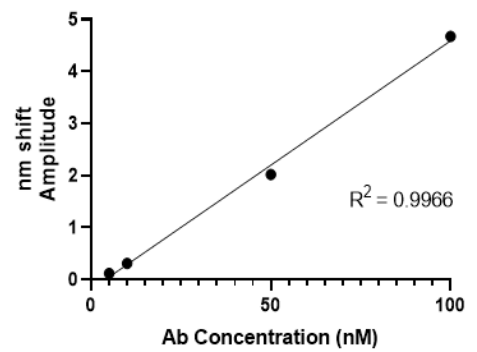

b.

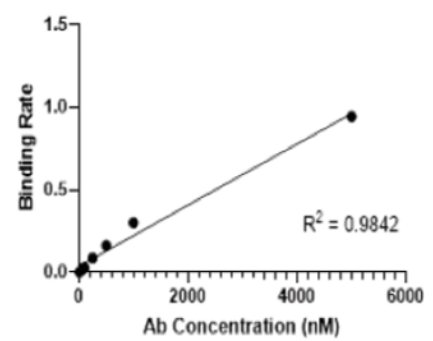

C.

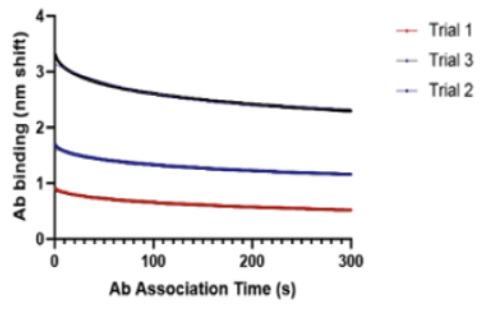

Figure S7. Quantitation and characterization of affinity-column purified anti-DNP antibody a. The standard curve used to quantify the concentration of anti-DNP specific antibody (sAb) isolated in the affinity chromatography enriched sample. b. The standard curve used to quantify the total amount of IgG in the anti-DNP antibody depleted sample. c. BLI sensorgram of the dissociation step showing the 'one phase exponential decay' curve fit (on Graphpad Prism 8) used to determine the binding affinity of affinity -column enriched anti-DNP Ab for the DNP hapten

This method of antibody quantification relies on the assumption that the isolated serum antibody has a similar binding affinity for probe-1 as mmAb. However, as seen from Table 1 and Figure 6A of the main manuscript, it is likely that $\mathrm{mmAb}$ has a higher affinity $\left(K_{d} \sim 80 \mathrm{nM}\right)$ for the DNP hapten of Compound 1 than the isolated serum antibody $\left(K_{d} \sim 460 \mathrm{nM}\right)$. This means that at the same fixed concentration of antibody, more mmAb than isolated serum antibody would bind to the probe. More $\mathrm{mmAb}$ binding to the probe would result in a higher $\mathrm{nm}$ shift amplitude for the mmAb sample compared to the serum antibody at the same concentration, as mass increases the $\mathrm{nm}$ shift amplitude. As a result, the standard curve could have underestimated the concentration of serum antibody isolated as the nm shift values reported for each concentration in the curve may be higher than they would be for serum antibody binding.

The nm shift amplitude of the isolated anti-DNP antibody sample was 2.83 . When this value is substituted into the equation from the standard curve, the concentration of anti-DNP antibody isolated from serum is calculated to be $63 \mathrm{nM}$. The calculation is shown below: 
$\mathrm{nm}$ shift amplitude $=0.04779(\mathrm{Ab}$ concentration in $\mathrm{nM})-0.1918$

$2.83=0.04779(\mathrm{Ab}$ concentration in $\mathrm{nM})-0.1918$

$3.0218=0.04779(\mathrm{Ab}$ concentration in $\mathrm{nM})$

$63.23=\mathrm{Ab}$ concentration in $\mathrm{nM}$

Estimation of endogenous concentration of anti-DNP antibody in pooled human serum and pan IgG solution

The concentration of endogenous anti-DNP antibody in pooled human serum was estimated by comparing the fraction of anti-DNP isolated using affinity chromatography to the total IgG concentration in the sample loaded onto the column. From the affinity column, $0.5 \mathrm{~mL}$ of $63 \mathrm{nM}$ anti-DNP antibody was isolated. As the molecular weight of $\operatorname{IgG}$ is $150 \mathrm{kDa}, 63 \mathrm{nM}$ of anti-DNP antibody is about 0.00945 $\mathrm{mg} / \mathrm{mL}$. Therefore, the total amount of anti-DNP antibody isolated from $109.2 \mathrm{mg}$ ( $3 \mathrm{~mL}$ of $36.4 \mathrm{mg} / \mathrm{mL}$ ) of human serum IgG was $0.00472 \mathrm{mg}(0.5 \mathrm{~mL}$ X $0.00945 \mathrm{mg} / \mathrm{mL})$. The fraction of anti-DNP IgG in the human serum IgG sample is $4.3 \times 10^{-5}$, as seen in the following calculation:

amount of anti-DNP antibody in sample/ total amount of antibody in sample $=$ fraction of anti-DNP IgG

$0.00472 \mathrm{mg} / 109.2 \mathrm{mg}=$ fraction of anti-DNP IgG

$4.3 \times 10^{-5}=$ fraction of anti-DNP IgG

The concentration of IgG in human serum is assumed to be $7-16 \mathrm{mg} / \mathrm{ml} .{ }^{6}$ Using an average value of 11.5 $\mathrm{mg} / \mathrm{mL}$, the concentration of anti-DNP IgG in human serum would be $5.0 \times 10^{-4} \mathrm{mg} / \mathrm{mL}$, which is on the order of $10^{-9} \mathrm{M}$. This value was calculated as shown below:

concentration of $\operatorname{IgG}$ in serum $\mathrm{X}$ fraction of anti-DNP IgG in serum $\operatorname{IgG}=$ concentration of anti-DNP Ab in serum $11.5 \mathrm{mg} / \mathrm{mL}$ X $4.3 \times 10^{-5}=$ concentration of anti-DNP Ab in serum

$5.0 \times 10^{-4} \mathrm{mg} / \mathrm{mL}=$ concentration of anti-DNP $\mathrm{Ab}$ in serum

$\sim 3 \mathrm{nM}=$ concentration of anti-DNP Ab in serum

This same method was used to estimate the concentration of endogenous anti-DNP Ab in the pan $\operatorname{IgG}$ solution used in CD16 $\alpha$ activation assays. This pan IgG solution was estimated to have an endogenous antiDNP antibody concentration of $10 \mathrm{nM}$ and this value was calculated as shown below:

concentration of pan IgG X fraction of anti-DNP IgG in total $\operatorname{IgG}=$ concentration of anti-DNP in pan IgG

$36.4 \mathrm{mg} / \mathrm{mL} \mathrm{X} 4.3 \times 10^{-5}=$ concentration of anti-DNP in pan IgG solution

$1.6 \times 10^{-3} \mathrm{mg} / \mathrm{mL}=$ concentration of anti-DNP in pan IgG solution

$\sim 10 \mathrm{nM}=$ concentration of anti-DNP in pan IgG solution

$\underline{\text { Total IgG quantitation }}$

Total IgG concentration was determined using the initial binding rate of the isolated antibody sample to ProG probes on the Octet Red96. ProG probes are Fc capture probes that bind the Fc portion of specifically IgG antibodies. A higher concentration of IgG would result in more IgG initially loading onto the probe (a higher initial rate) before an equilibrium can be established. The initial binding rate of antibody to the probe was measured by monitoring antibody binding (nm shift) over time for the first 20 seconds the probe was placed in the antibody solution. The initial binding rate was then linearly derived from the curve of antibody binding (nm shift) over time using the 'calculate binding rate' option of the 'quantitation' method in the Octet Systems Data Analysis software. 
A standard curve was constructed using $5-5000 \mathrm{nM}$ of mmAb in PBS. The equation of the standard curve is (binding rate, $\left.s^{-1}\right)=0.0001852$ ( $\operatorname{Ig} G$ concentration, $\left.n M\right)+0.03719$ and was derived using the 'simple linear regression' model on GraphPad Prism 8. The serum IgG sample depleted of anti-DNP was first diluted 1:10 in PBS before being quantified. The initial binding rate of the anti-DNP depleted serum IgG sample was $0.639 \mathrm{~s}^{-1}$, which calculated to $3250 \mathrm{nM}$ of $\mathrm{IgG}$ in the sample. Taking into account the 1:10 dilution, the total concentration of IgG in the anti-DNP depleted serum IgG sample was $32 \mu \mathrm{M}$.

Affinity analysis of isolated anti-DNP antibody in the anti-DNP enriched sample via BLI.

The experiment was conducted using an Octet Red96 (ForteBio) with the temperature set at $25^{\circ} \mathrm{C}$, the RPM set at 1000 and the acquisition rate set at $5 \mathrm{~Hz}$. A volume of $250 \mu \mathrm{L}$ of each solution was loaded into a black flat-bottom 96-well plate (Grenier). Streptavidin probes from Fortebio were placed in 1X Kinetics Buffer (Fortebio) for 20 minutes prior to experiment for wetting. The experiment begins by placing the streptavidin probes in $1 \mathrm{X}$ Kinetics Buffer for three minutes to establish a baseline. Compound 1 was then loaded onto the probes by placing the probes in a $500 \mathrm{nM}$ Compound 1 solution for three minutes. The probes were placed in 1X Kinetics Buffer for 30 seconds in order to re-establish a baseline. Association of the anti-DNP antibody in the anti-DNP antibody enriched sample to Compound $\mathbf{1}$ was measured by placing the probe into the anti-DNP antibody enriched solution, that was estimated to contain $60 \mathrm{nM}$ of anti-DNP antibody (sAb), for 5 minutes. Dissociation of antibody from compound 1 was measured by placing the probe in $1 \mathrm{X}$ Kinetics Buffer for 10 minutes. The experiment was repeated twice, with an isolated anti-DNP antibody concentration of $50 \mathrm{nM}$ and 40 $\mathrm{nM}$ respectively, for a total of three replicates. The raw $\mathrm{nm}$ shift signal for the association and dissociation step obtained by the Octet Red96 was first baselined to the beginning of the association step ( $\mathrm{t}=0$ seconds) by subtracting the association signal at $\mathrm{t}=0$ from the measured signal at each time point. $k_{\text {off }}$ was extracted from the dissociation phase of the binding curve using the 'one-phase exponential decay' model in GraphPad Prism 8. The equation used was:

$$
A b \text { binding }=\left((\text { Ab binding })_{0}-N S\right) X e^{-k_{o f f} X \text { time }}+N S
$$

where time was in seconds, $\mathrm{Ab}$ binding signal was in $\mathrm{nm}$ shift values, and $k_{\text {off }}$ was in $\mathrm{s}^{-1} \cdot \mathrm{k}_{\text {off }}$ was constrained to greater than zero. NS represents the non-specific binding and is fit by GraphPad Prism using the binding signal meausred at the highest time points. $K_{d}$ was determined using the equation $\mathrm{K}_{\mathrm{d}}=\mathrm{k}_{\mathrm{off}} / \mathrm{k}_{\mathrm{on}}$. The $k_{\text {off }}$ values used are the average ones determined from the BLI assay as described previously. The $k_{\text {on }}$ value used was $2 \times 10^{4} \mathrm{M}^{-1} \mathrm{~s}^{-1}$, which is the previously estimated $k_{o n}$ value of an immobilized small molecule associating with IgG antibody.

\section{cARM 3 Selective Recruitment of Serum anti-DNP Ab using BLI}

Anti-DNP IgG was isolated from human serum IgG (Cedarlane Labs) using affinity chromatography. The enriched anti-DNP antibody sample had $63.19 \mathrm{nM}$ of anti-DNP antibody in $1.92 \mu \mathrm{M}$ of total $\mathrm{IgG}$. The enriched antibody sample was reacted with $2.5 \mu \mathrm{M}$ of cARM 3 in PBS overnight at room temperature. A sample of $32.75 \mu \mathrm{M}$ IgG that was depleted of anti-DNP antibody was also reacted with $2.5 \mu \mathrm{M}$ of cARM 3 in PBS overnight at room temperature as a negative control. 
The ability of cARM 3 to recruit the tumour antigen PSMA to anti-DNP antibodies was measured using BLI. The experiment was conducted using an Octet Red96 (ForteBio) with the temperature set at $25{ }^{\circ} \mathrm{C}$, the RPM set at 1000, and the acquisition rate set at $5 \mathrm{~Hz}$. The isolated anti-DNP and cARM 3 reaction samples were suspended in 1X Kinetics Buffer (ForteBio) by doping in a 1:10 dilution of 10X Kinetics Buffer stock. A volume of $200 \mu \mathrm{L}$ of each solution was loaded into a black flat-bottom 96-well plate (Grenier). Fc capture (ProG) biosensors from ForteBio were placed in 1X Kinetics Buffer for 20 minutes prior to the experiment for wetting. First, the probes were placed in 1X Kinetics Buffer for 4 minutes to establish a baseline. Then the probes were submerged in the antibody-cARM 3 reaction sample for 3 minutes to load the antibodies onto the probe. After the loading step, the probes were submerged for 20 minutes in $5 \mathrm{mM}$ DNP-glycine in Kinetics Buffer, which acts as a competitor to disrupt any non-covalent interactions between cARM 3 and the antibodies. A wash step where the probe was submerged in $1 \mathrm{X}$ Kinetics Buffer for 10 minutes to allow any non-specific interactions to dissociate from the probe was repeated eight times and a different well of $1 \mathrm{X}$ Kinetics Buffer was used for each repeat. Association of PSMA to the probe was measured by submerging the probe in $500 \mathrm{nM}$ PSMA for 10 minutes. Dissociation of PSMA from the probe was measured by submerging the probe in $1 \mathrm{X}$ Kinetics Buffer for 10 minutes.

The raw nm shift signal for the association and dissociation step obtained by the Octet Red96 was baselined to the beginning of the association step ( $\mathrm{t}=0$ seconds) by subtracting the association signal at $\mathrm{t}=0$ from the measured signal at each time point.

$\underline{\text { Anti-DNP antibody depletion }}$

$0.002 \mathrm{~g}$ of DNP-BSA(Invitrogen A23018) was coupled to $0.2 \mathrm{~g}$ of Cyanogen bromide-activated Sepharose 4B beads (Sigma-Aldrich C9142) in basic coupling buffer $\left(0.1 \mathrm{M} \mathrm{NaHCO}_{3}\right.$ buffer containing $0.5 \mathrm{M} \mathrm{NaCl}$, $\mathrm{pH}=8.4)$ for 12 hours at $4{ }^{\circ} \mathrm{C}$. Unreacted groups were blocked using a $0.2 \mathrm{M}$ glycine $(\mathrm{pH}=8.0)$ solution for 1 hour at room temperature. $3 \mathrm{~mL}$ of $36.4 \mathrm{mg} / \mathrm{mL}$ human serum IgG (Cedarlane Labs) was applied to the column in a binding buffer consisting of $0.02 \mathrm{M}$ sodium phosphate and $0.15 \mathrm{M} \mathrm{NaCl}$ at a $\mathrm{pH}$ of 7.4 . The sample was incubated with the column for 12 hours at $4{ }^{\circ} \mathrm{C}$. The flow through from the column was used to provide anti-DNP depleted IgG, which was concentrated with a $30 \mathrm{~K}$ MWCO Amicon ultracentrifugal filter.

$\underline{\text { Anti-DNP antibody enrichment }}$

$0.002 \mathrm{~g}$ of DNP-BSA (Invitrogen) was coupled to $0.2 \mathrm{~g}$ of Cyanogen bromide-activated Sepharose $4 \mathrm{~B}$ beads (Sigma-Aldrich) in basic coupling buffer $\left(0.1 \mathrm{M} \mathrm{NaHCO}_{3}\right.$ buffer containing $\left.0.5 \mathrm{M} \mathrm{NaCl}, \mathrm{pH}=8.4\right)$ for 12 hours at $4{ }^{\circ} \mathrm{C}$. Unreacted groups were blocked using a $0.2 \mathrm{M}$ glycine $(\mathrm{pH}=8.0)$ solution for 1 hour at room temperature. $3 \mathrm{~mL}$ of $36.4 \mathrm{mg} / \mathrm{mL}$ human serum IgG (Cedarlane Labs) was applied to the column in a binding buffer consisting of $0.02 \mathrm{M}$ sodium phosphate and $0.15 \mathrm{M} \mathrm{NaCl}$ at a $\mathrm{pH}$ of 7.4. The sample was incubated with the column for 12 hours at $4{ }^{\circ} \mathrm{C}$. The column was washed four times with $5 \mathrm{~mL}$ of wash buffer $(0.002 \%$ Tween 20 in PBS) and once with $5 \mathrm{~mL}$ of $0.2 \mathrm{M}$ glycine in wash buffer. Each wash step was 30 minutes long. $2 \mathrm{~mL}$ of elution buffer (6.67 mM DNP-glycine in wash buffer) was incubated with the column for 20 minutes to elute anti-DNP antibody from the column. The elution step was repeated a total of three times. The DNP-glycine was removed from the isolated anti-DNP antibody solution using a G-25 PD10 desalting column. The anti-DNP antibody solution was then concentrated using a 30K MWCO Amicon ultracentrifugal filter. 


\section{Spectra and Characterization Data}
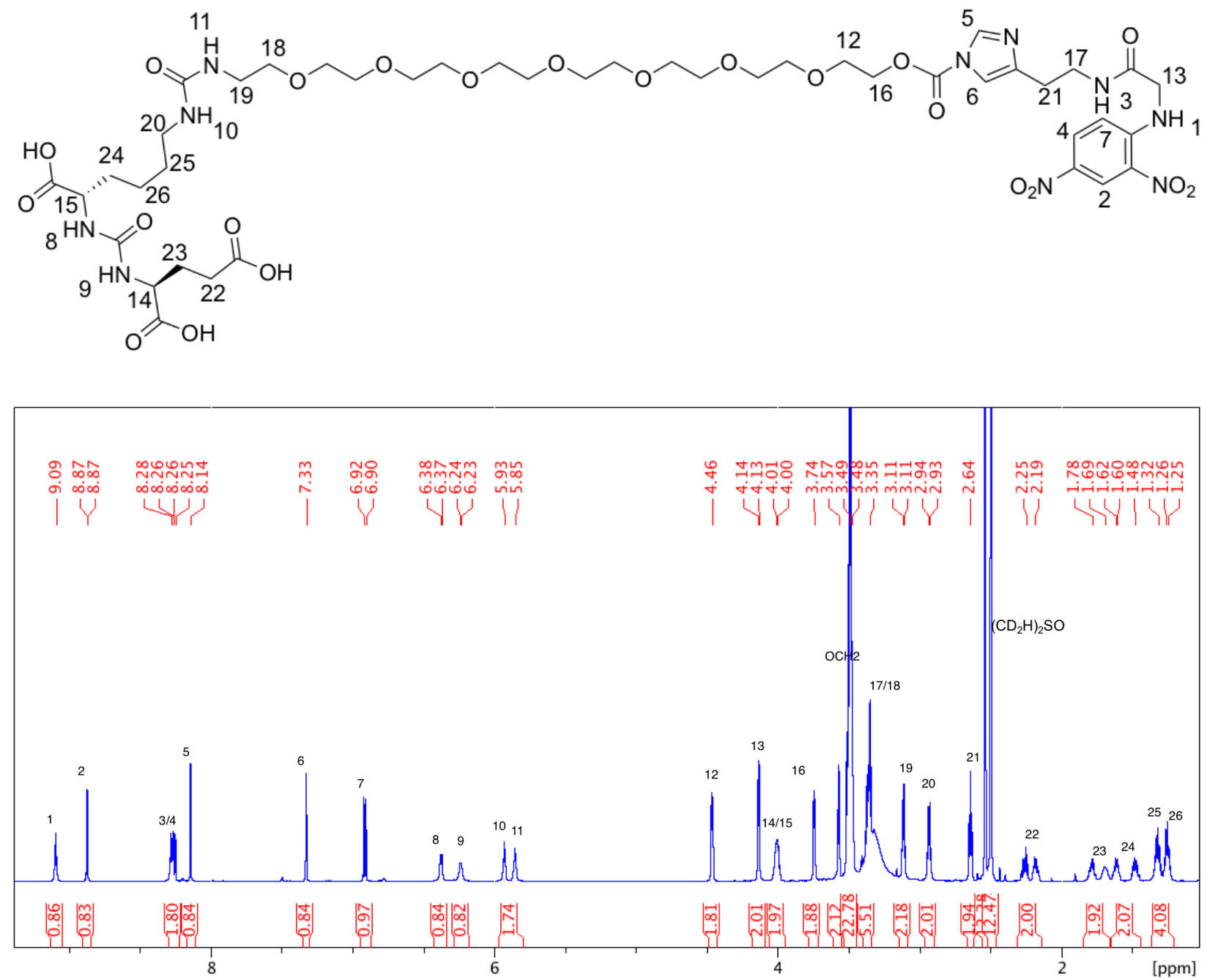

Figure S8. ${ }^{1} \mathrm{H}-\mathrm{NMR}$ of cARM 3, $\left(\mathrm{CD}_{3}\right)_{2} \mathrm{SO}$. 


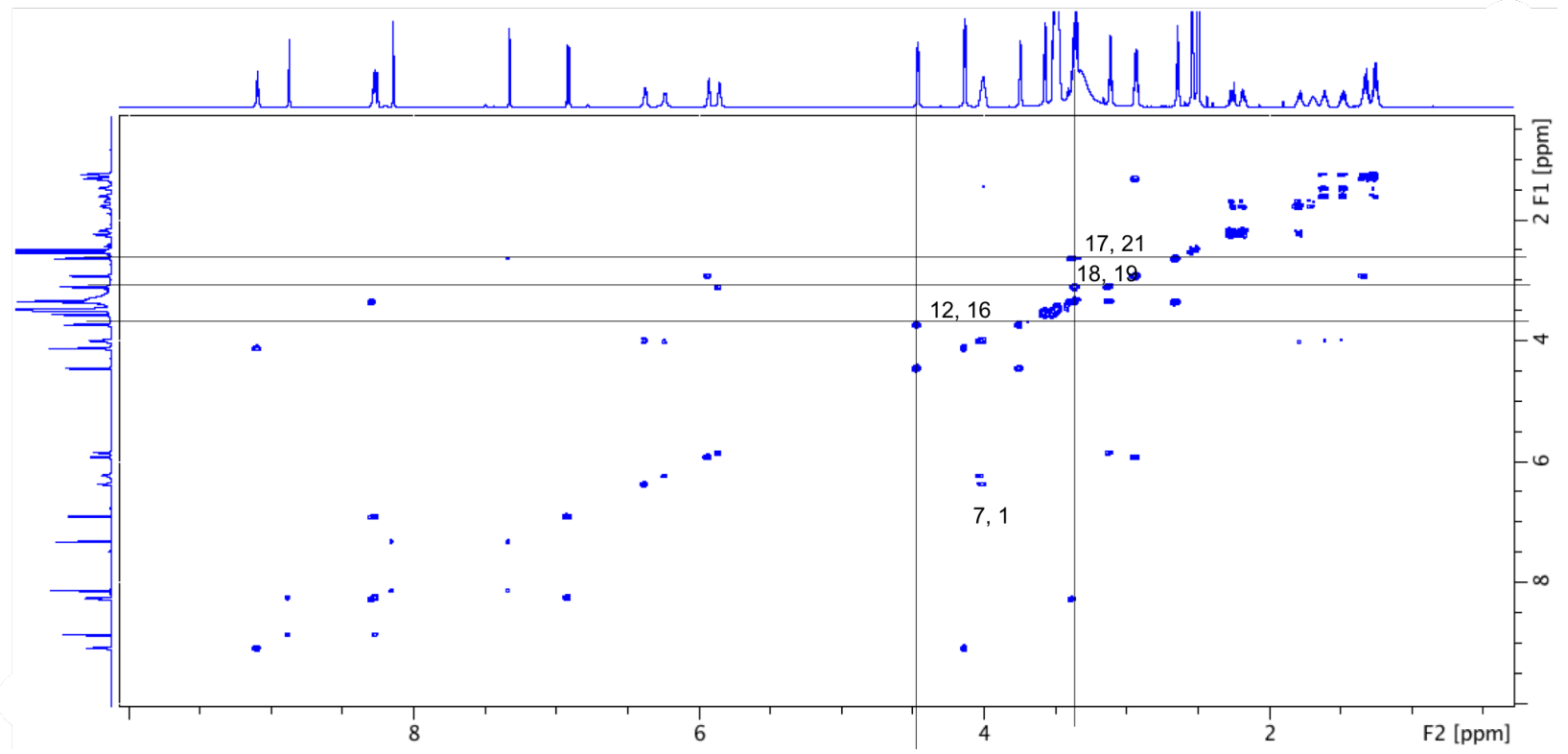

Figure S9. ${ }^{1} \mathrm{H}^{1} \mathrm{H}-\mathrm{COSY} \mathrm{NMR}$ of cARM 3, $\left(\mathrm{CD}_{3}\right)_{2} \mathrm{SO}$. DMSO-d 6

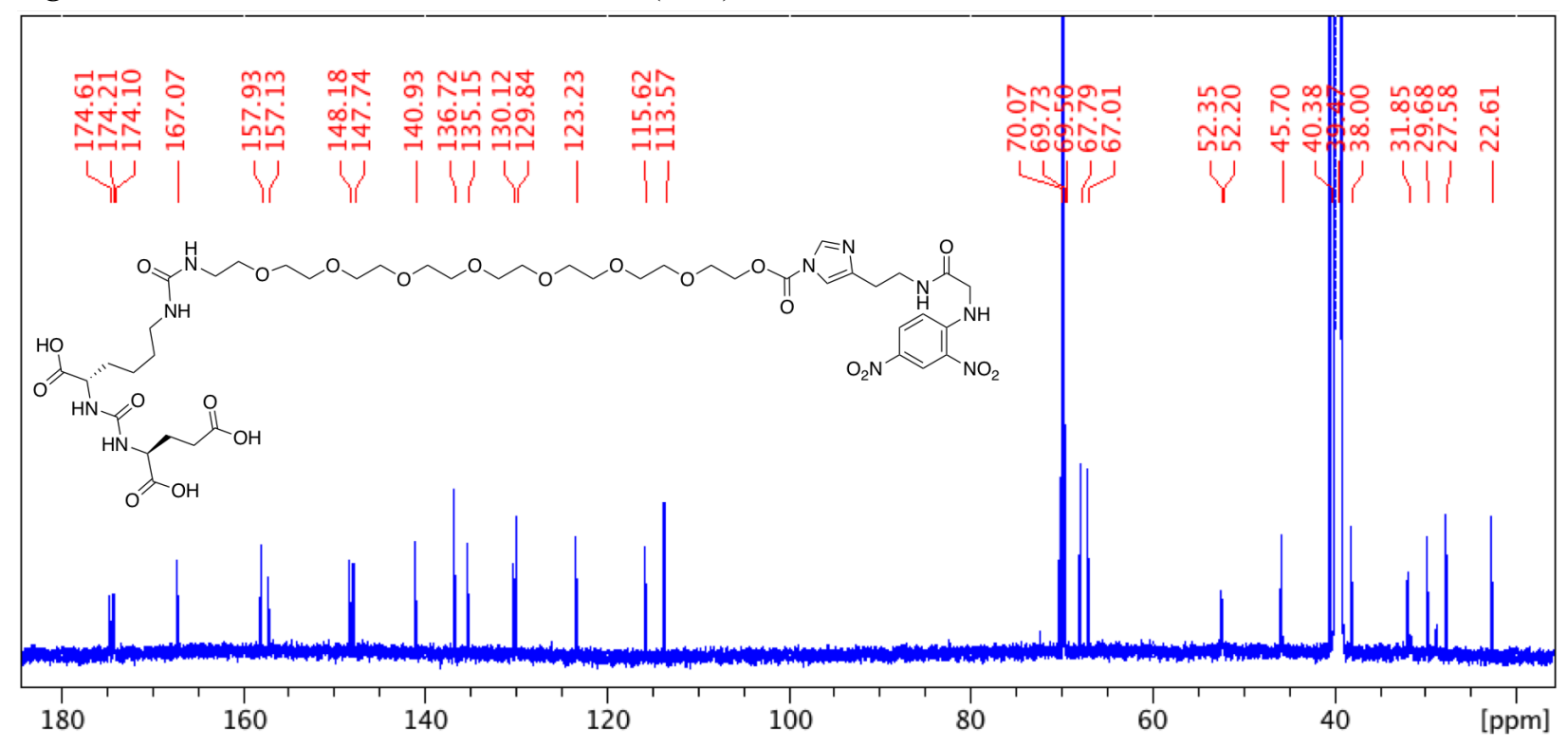

Figure S10. ${ }^{13} \mathrm{C}-\mathrm{NMR}$ of cARM 3, $\left(\mathrm{CD}_{3}\right)_{2} \mathrm{SO}$. 


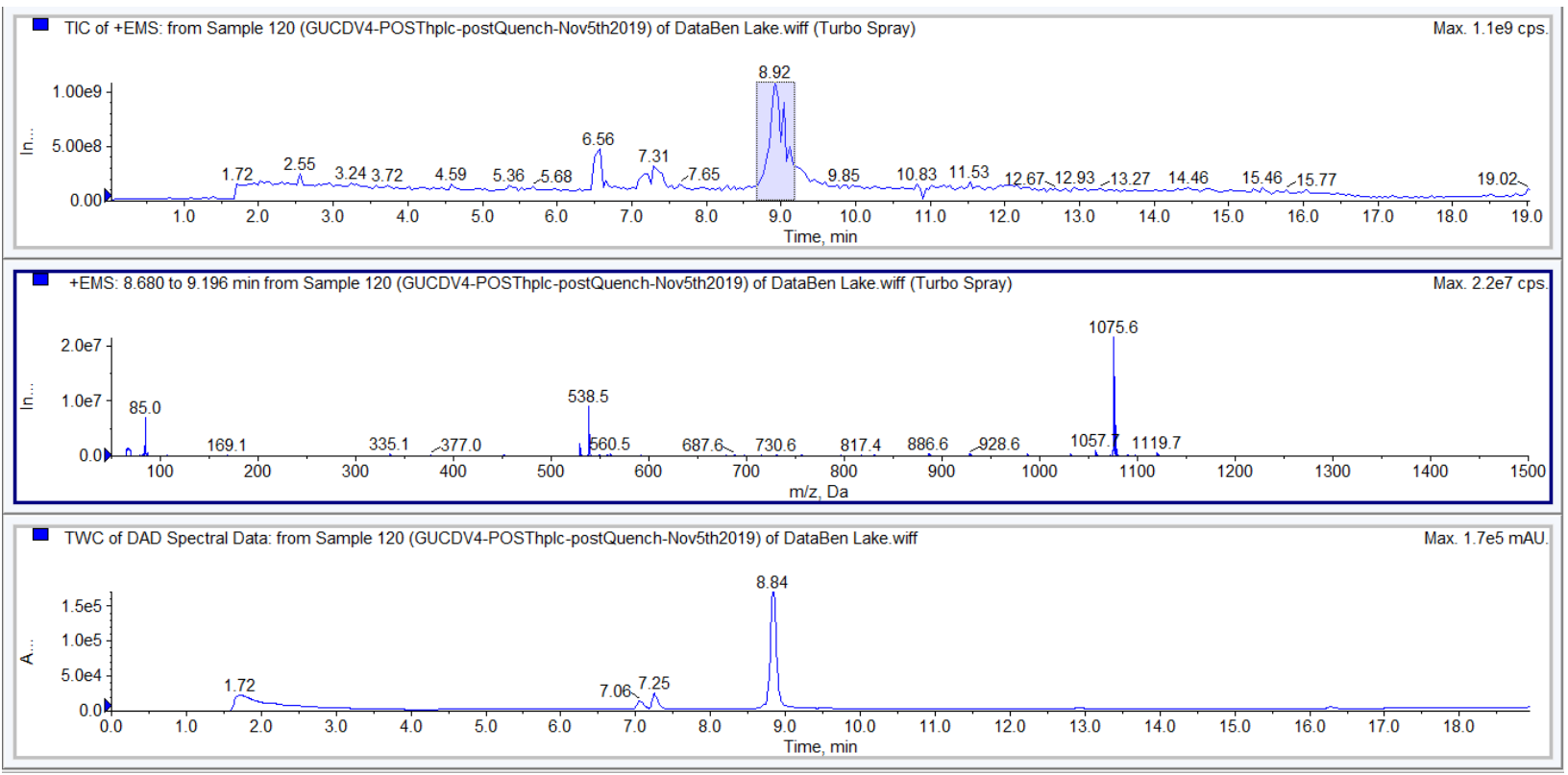

Figure S11. LC-MS trace of post column purified compound cARM3, (top) TIC trace, (middle) selected mass spectrum from TIC highlighted in blue box on TIC, (bottom) UV chromatogram. Minor peaks at 7.06, $7.25 \mathrm{~min}$ (UV chromatogram) and 6.56, $7.31 \mathrm{~min}$ (TIC trace), arise from acyl-imidazole hydrolysis products.

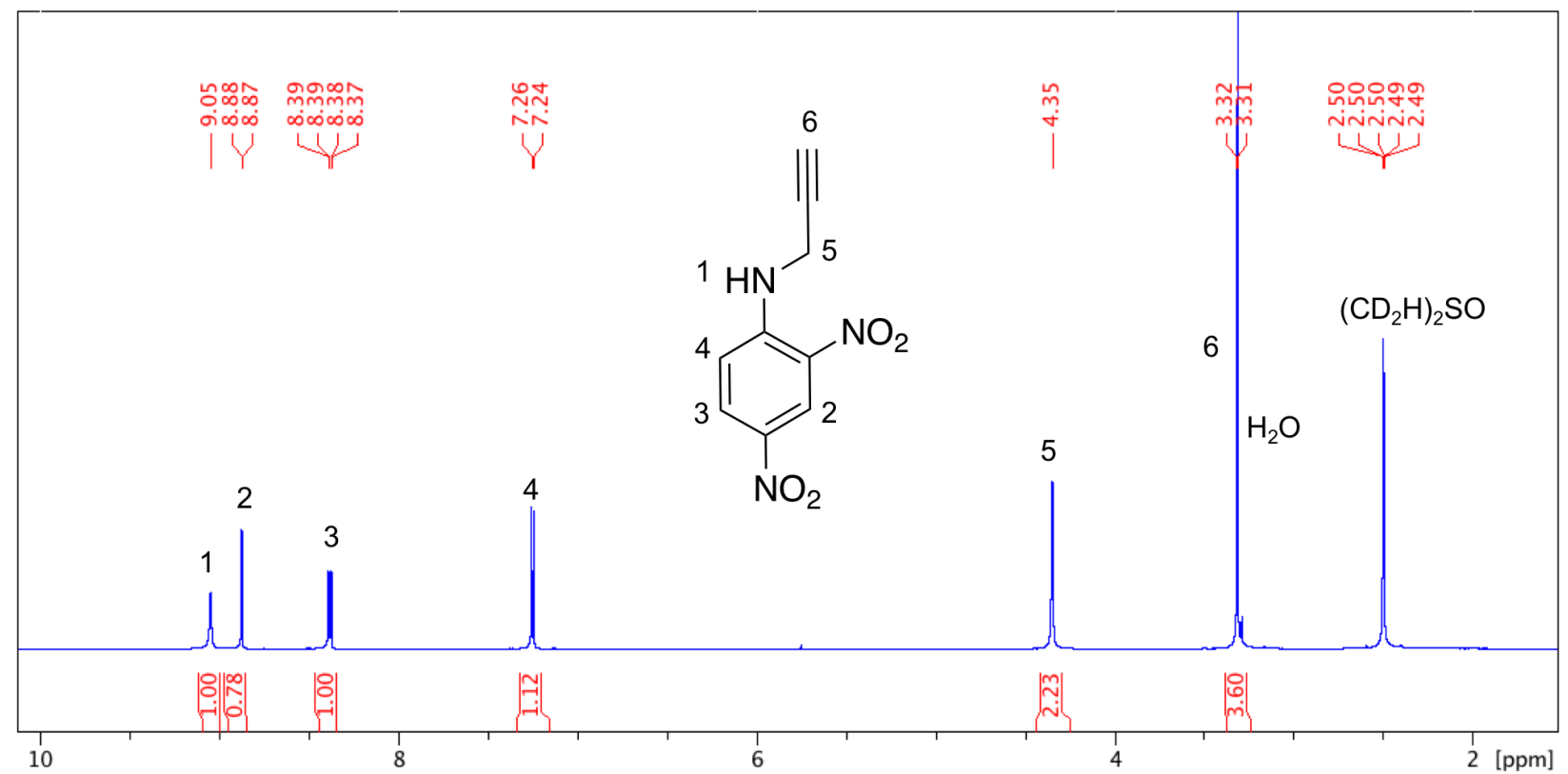

Figure S12. ${ }^{1} \mathrm{H}-\mathrm{NMR}$ of 7 , in $\left(\mathrm{CD}_{3}\right)_{2} \mathrm{SO}$. 


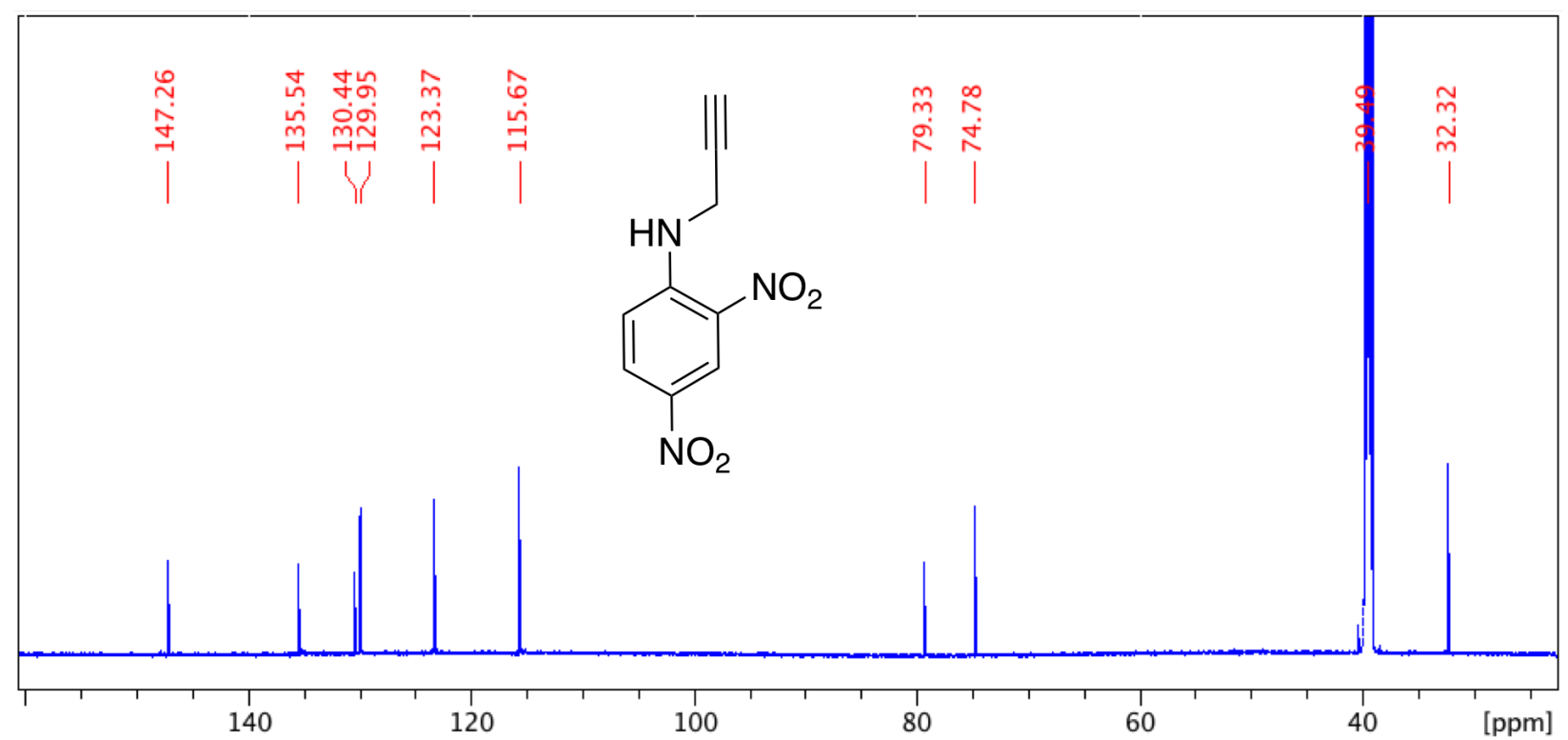

Figure S13. ${ }^{13} \mathrm{C}$-NMR of 7 , in $\left(\mathrm{CD}_{3}\right)_{2} \mathrm{SO}$.

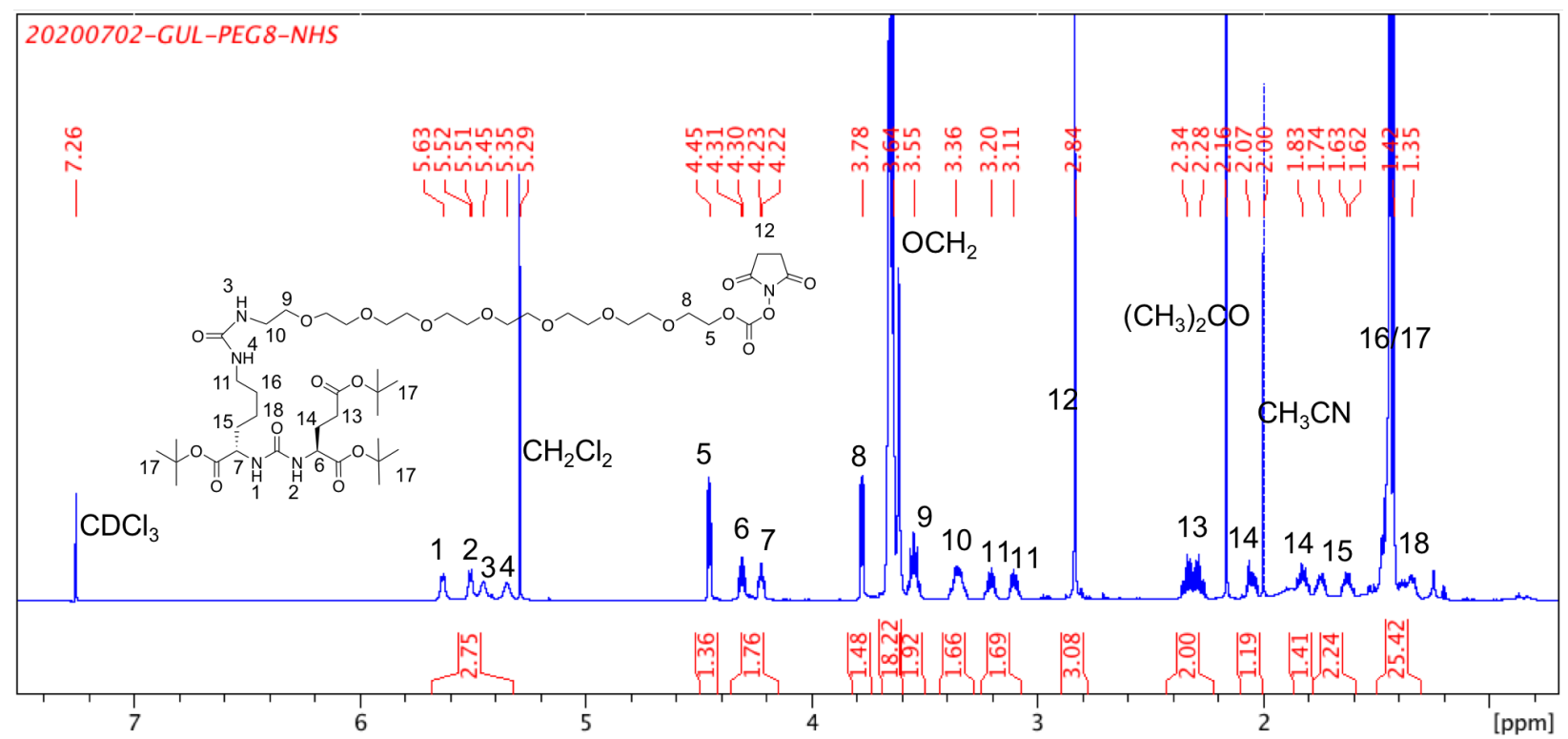

Figure S14. ${ }^{1} \mathrm{H}-\mathrm{NMR}$ of $\mathbf{1 4}, \mathrm{CDCl}_{3}$. 


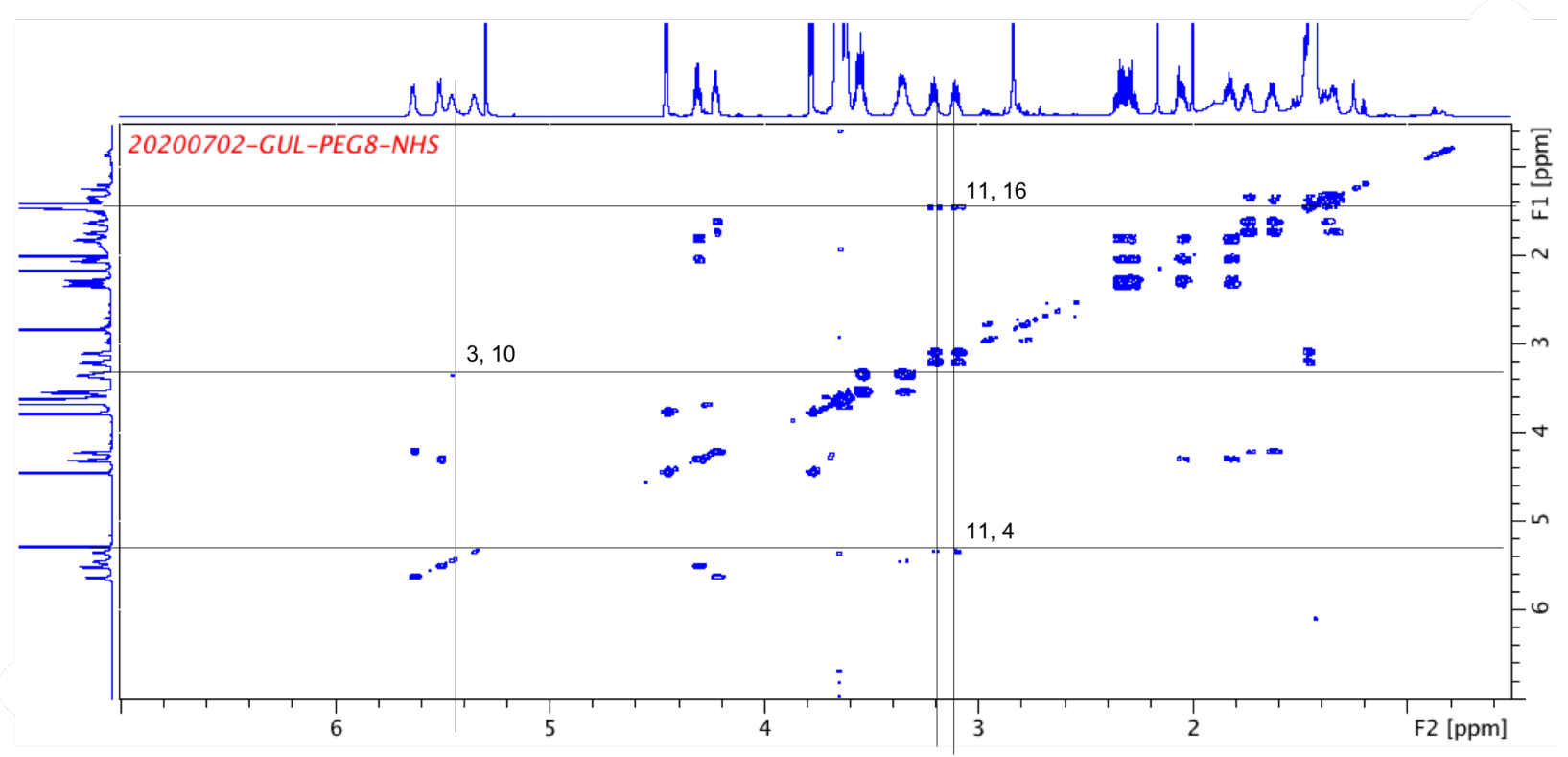

Figure S15. ${ }^{1} \mathrm{H}^{1} \mathrm{H}-\mathrm{COSY}$ NMR of $\mathbf{1 4}, \mathrm{CDCl}_{3}$.

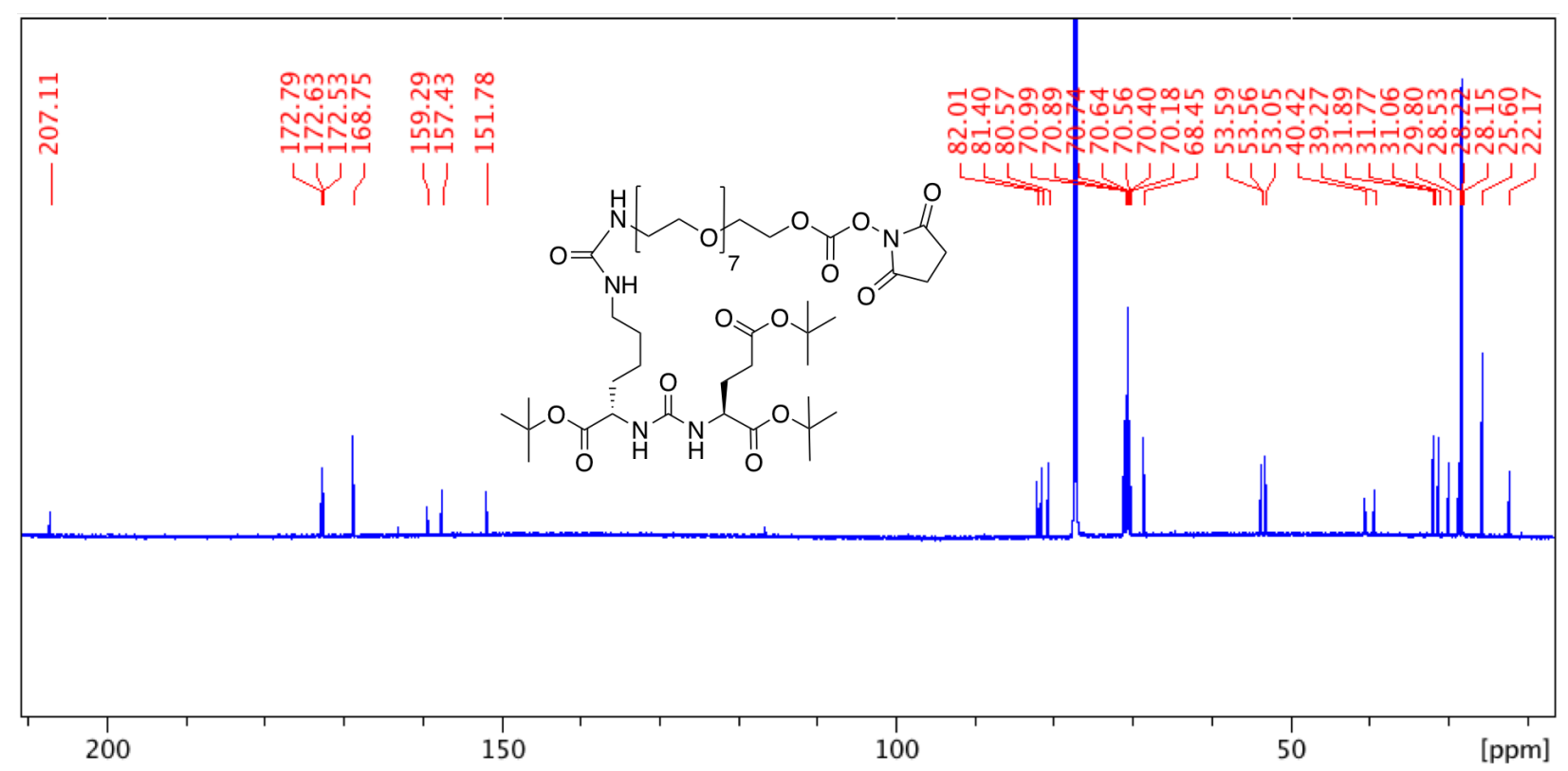

Figure S16. ${ }^{13} \mathrm{C}-\mathrm{NMR}$ of $\mathbf{1 4}, \mathrm{CDCl}_{3}$. 


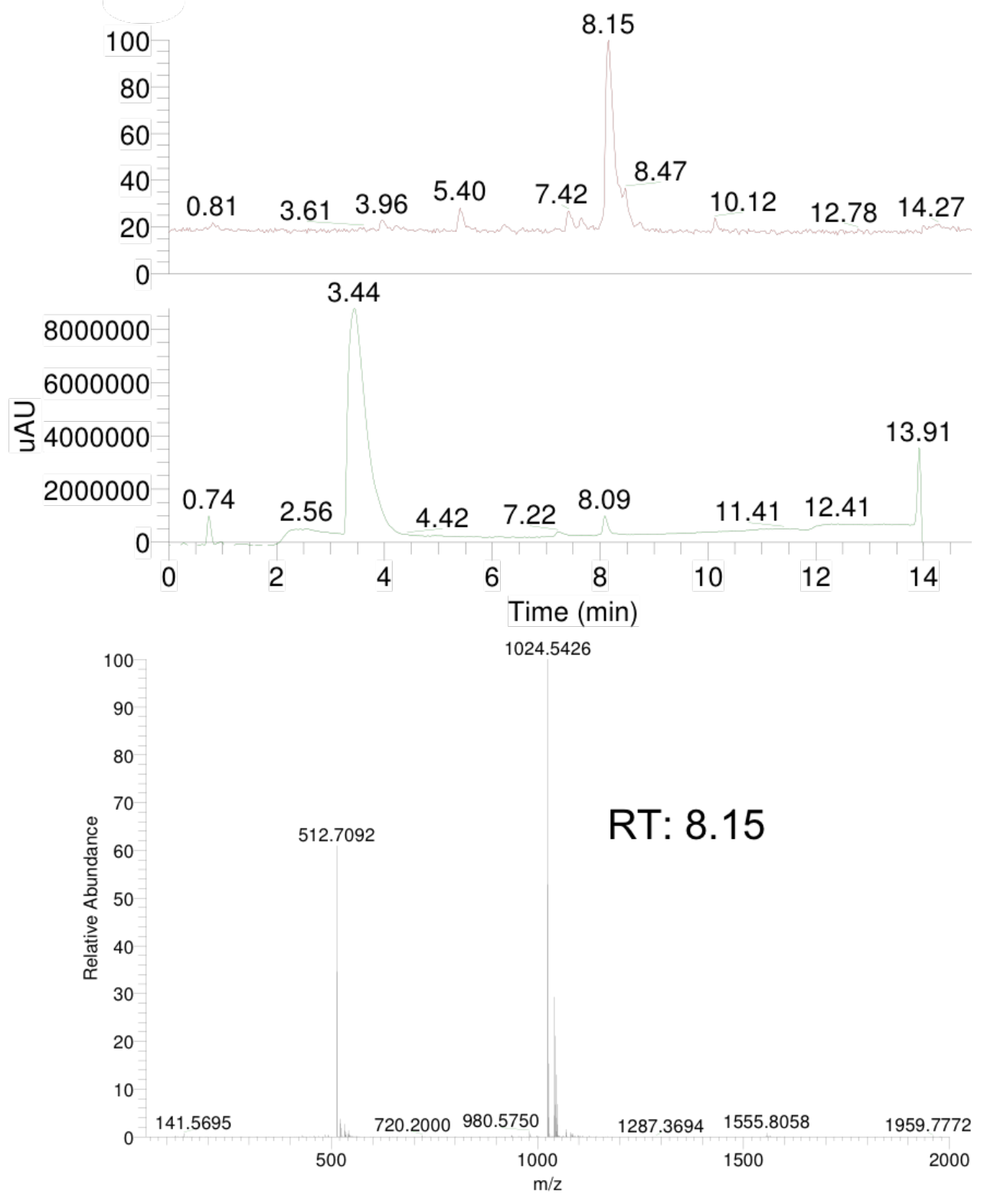

Figure S17. LC-MS trace of post column purified compound 14, (top) TIC trace, (bottom) selected mass spectrum from TIC with retention time (RT) noted, (middle) UV chromatogram. 


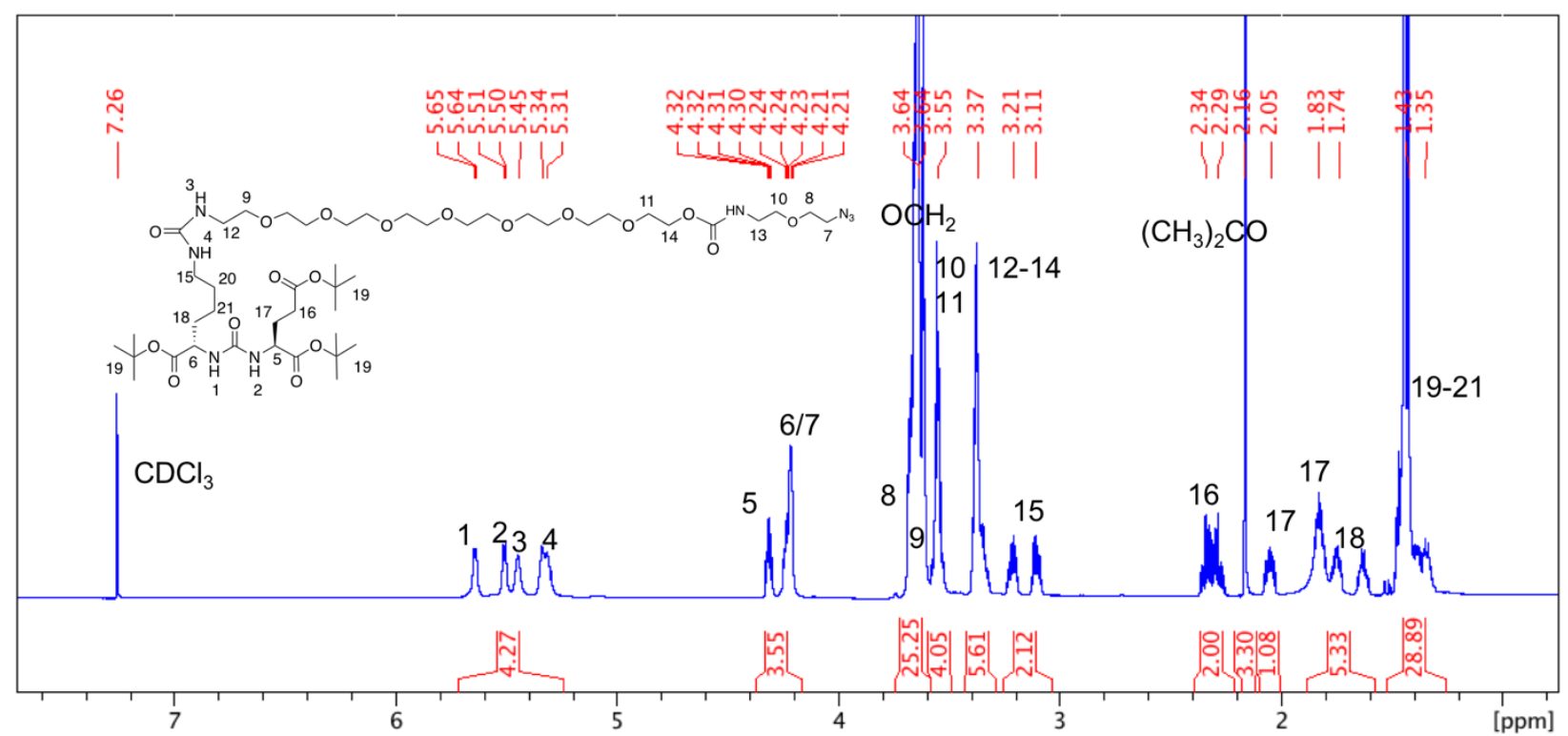

Figure S18. ${ }^{1} \mathrm{H}-\mathrm{NMR}$ of $\mathbf{1 5}, \mathrm{CDCl}_{3}$.

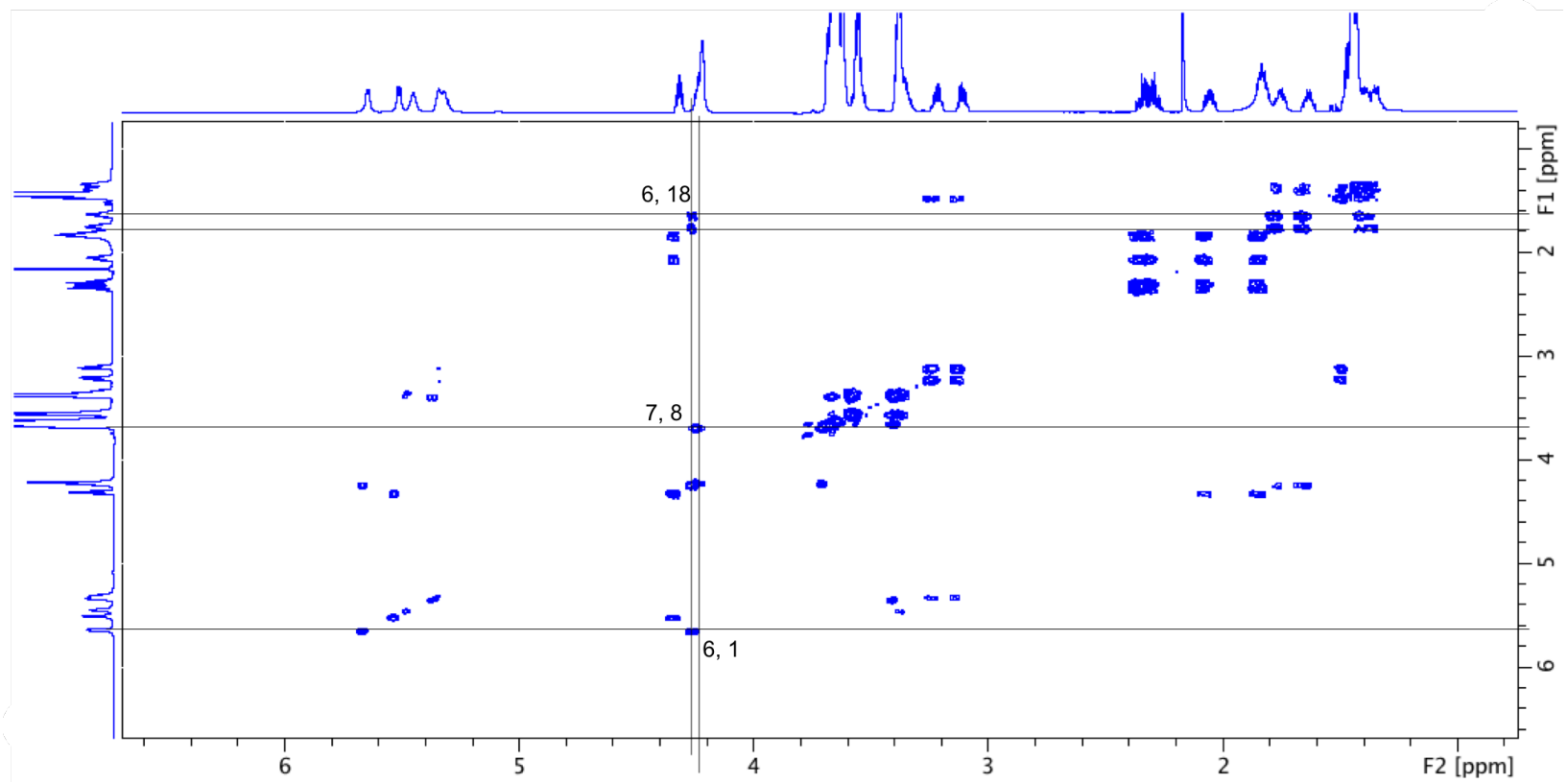

Figure S19. ${ }^{1} \mathrm{H}^{1} \mathrm{H}-\mathrm{COSY} \mathrm{NMR}$ of $\mathbf{1 5}, \mathrm{CDCl}_{3}$. 


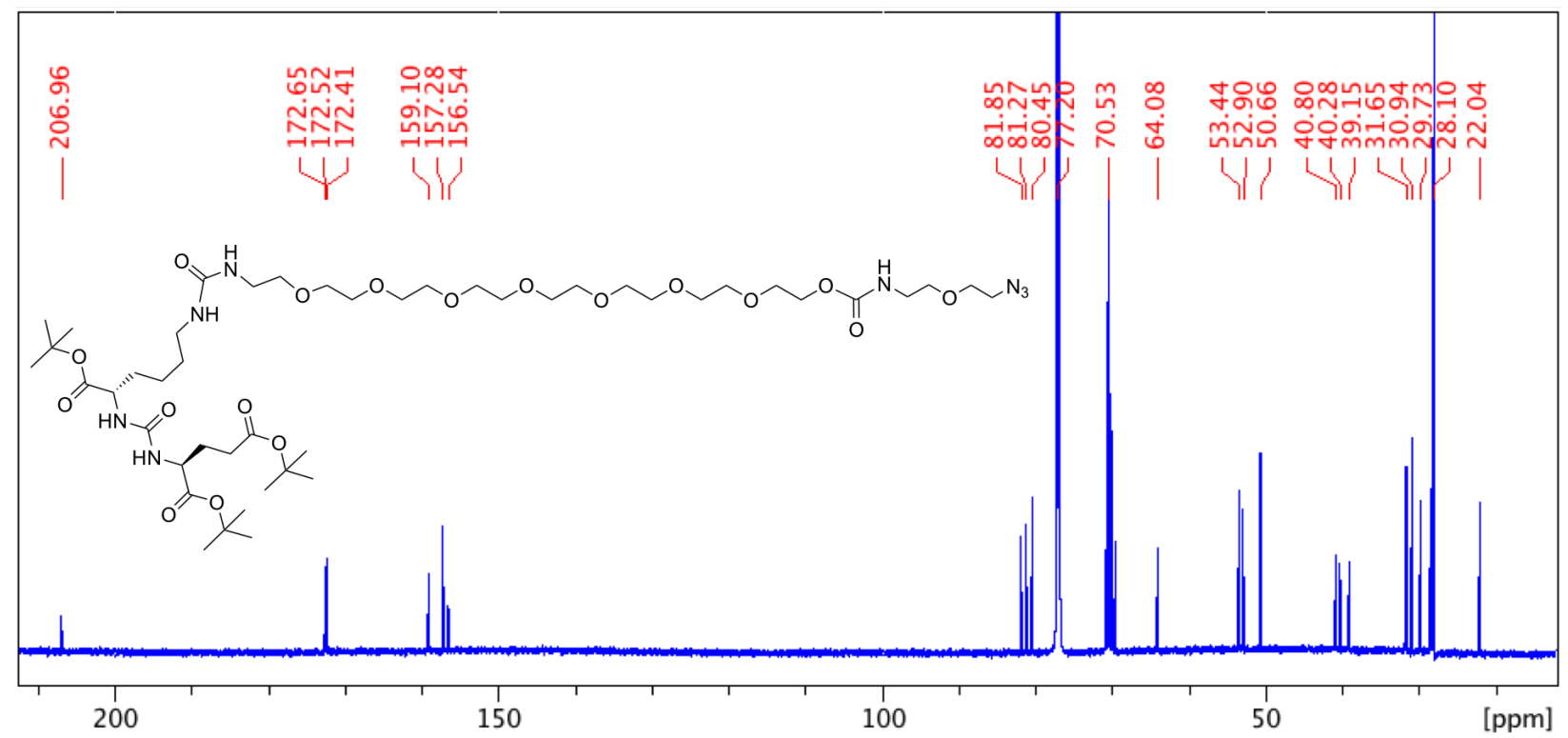

Figure $S 20 .{ }^{13} \mathrm{C}$-NMR of $\mathbf{1 5}, \mathrm{CDCl}_{3}$.

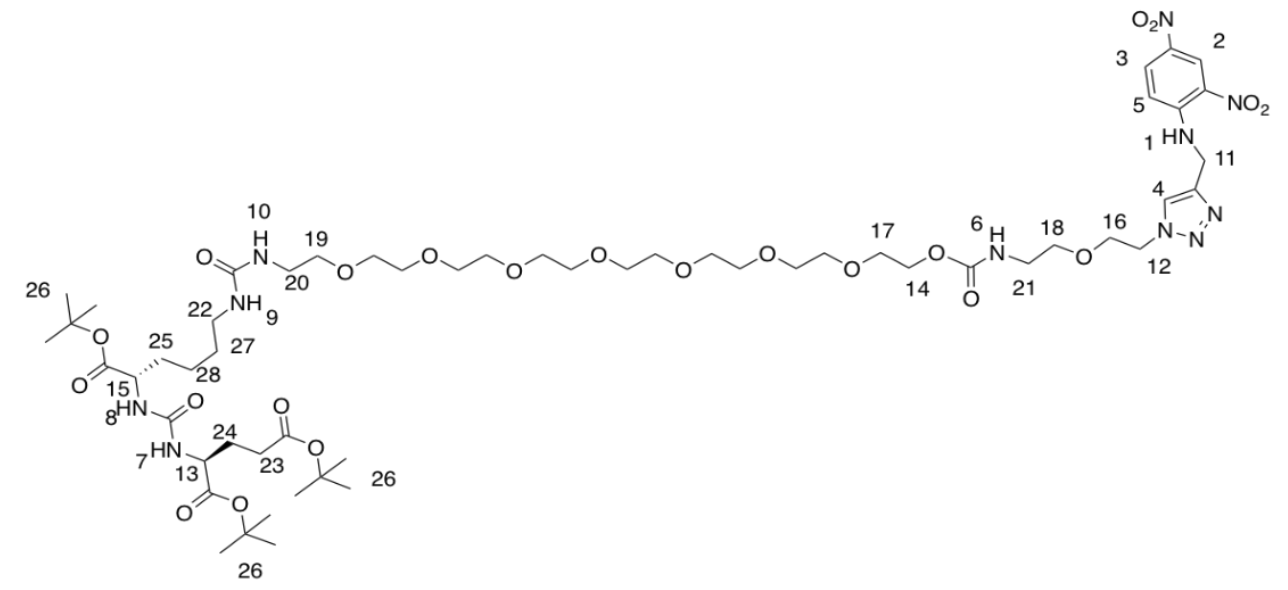




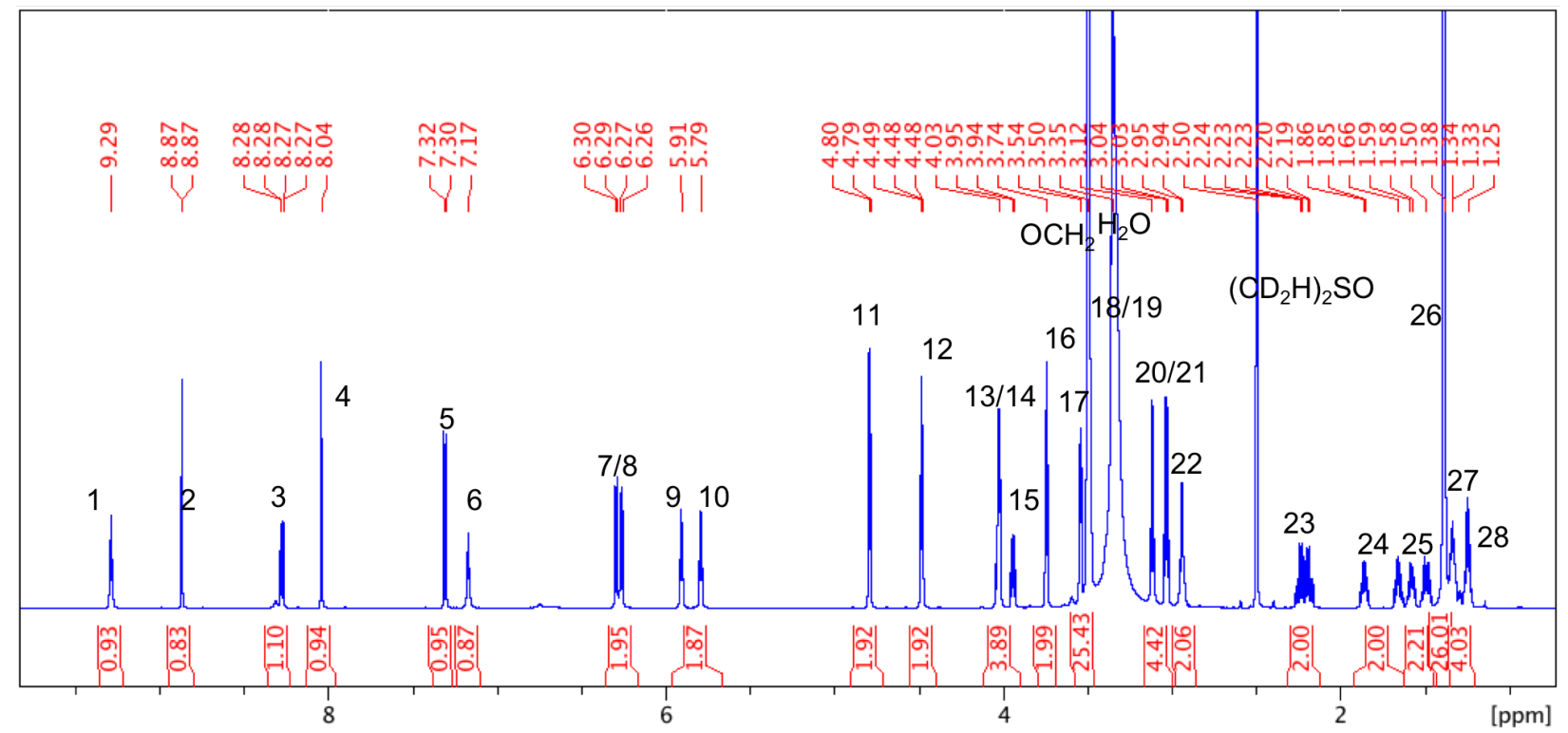

Figure $\mathrm{S} 21 .{ }^{1} \mathrm{H}-\mathrm{NMR}$ of $\mathbf{1 6},\left(\mathrm{CD}_{3}\right)_{2} \mathrm{SO}$.

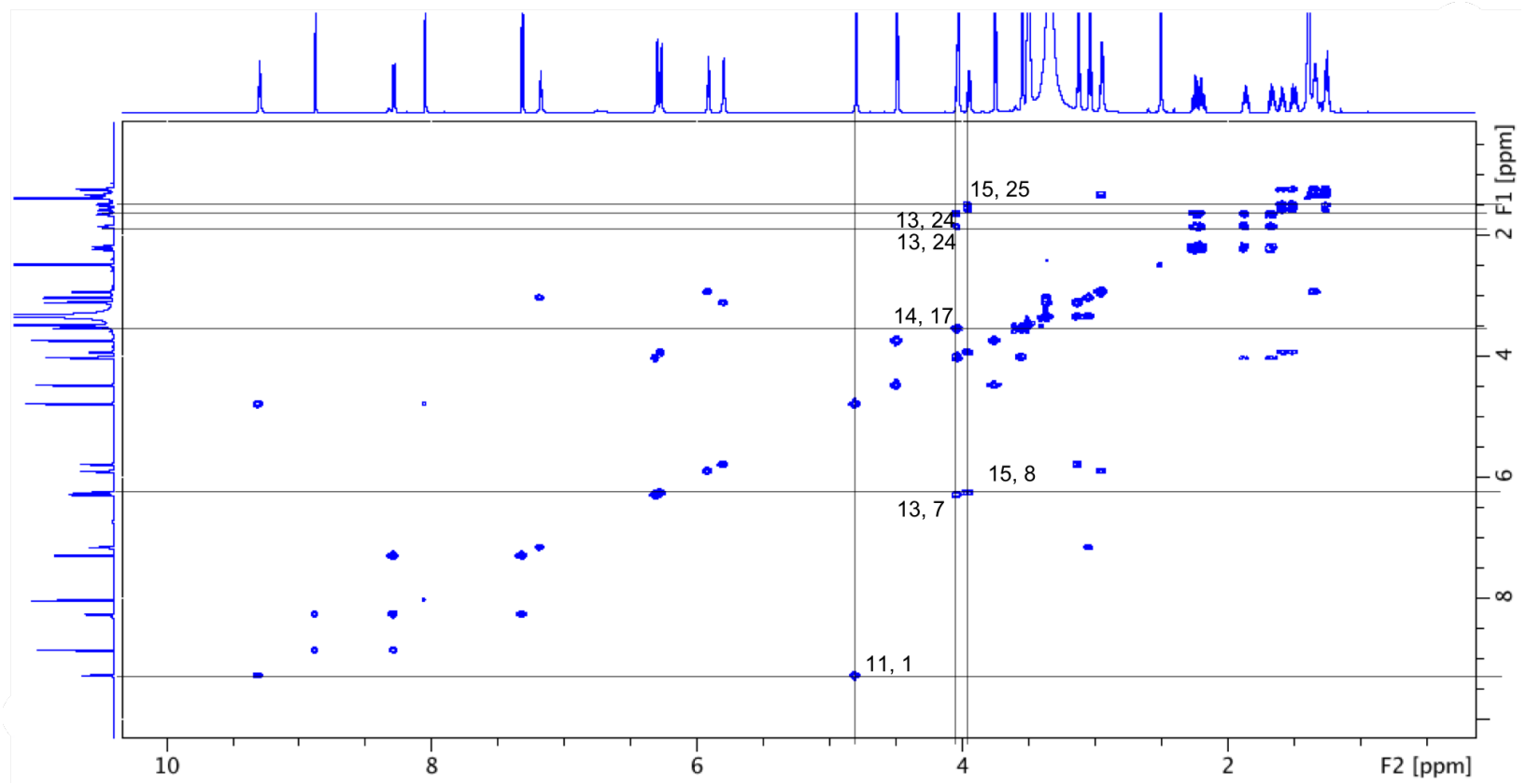

Figure $S 22 .{ }^{1} \mathrm{H}^{1} \mathrm{H}-\mathrm{COSY}$ NMR of $\mathbf{1 6},\left(\mathrm{CD}_{3}\right)_{2} \mathrm{SO}$. 


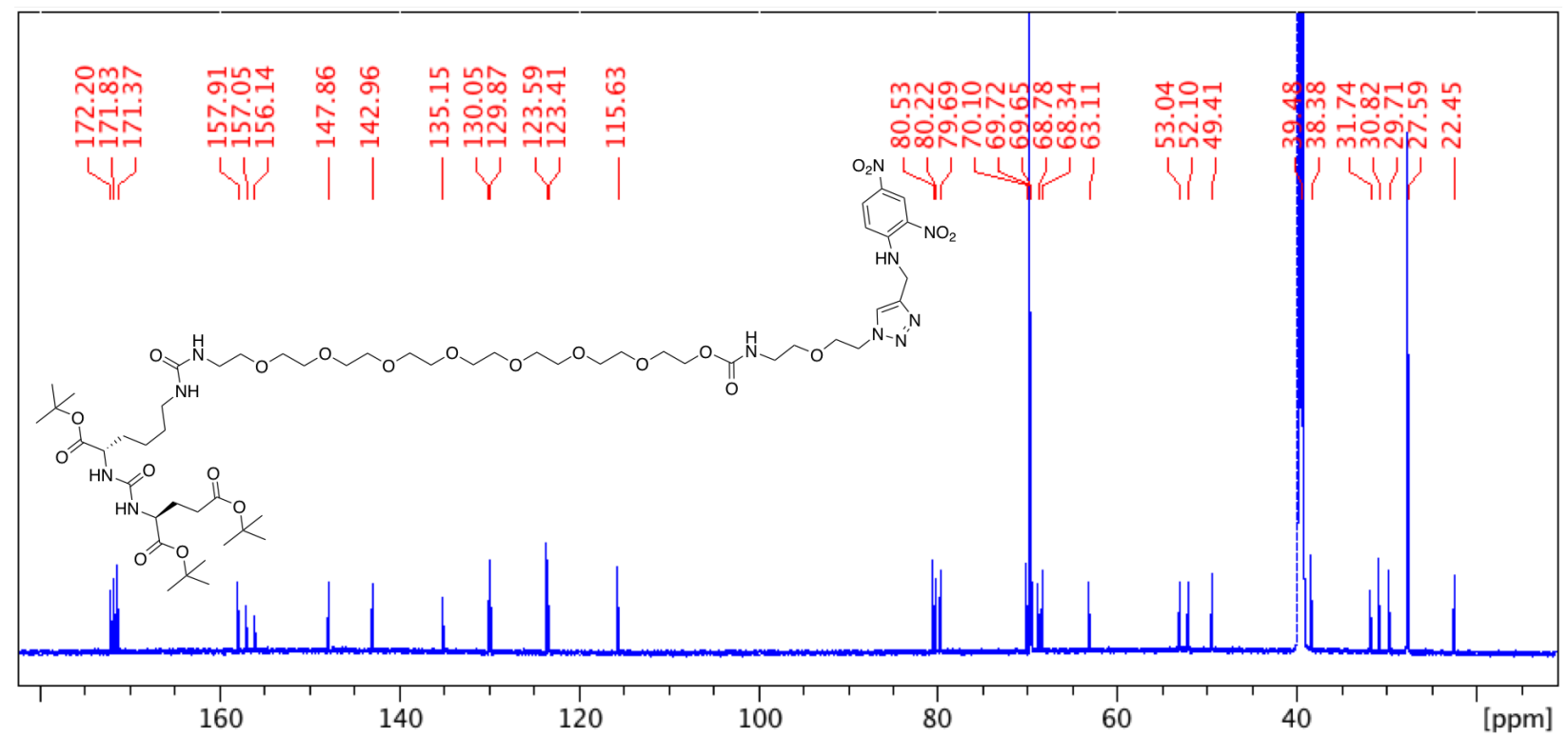

Figure S23. ${ }^{13} \mathrm{C}-\mathrm{NMR}$ of $\mathbf{1 6},\left(\mathrm{CD}_{3}\right)_{2} \mathrm{SO}$.
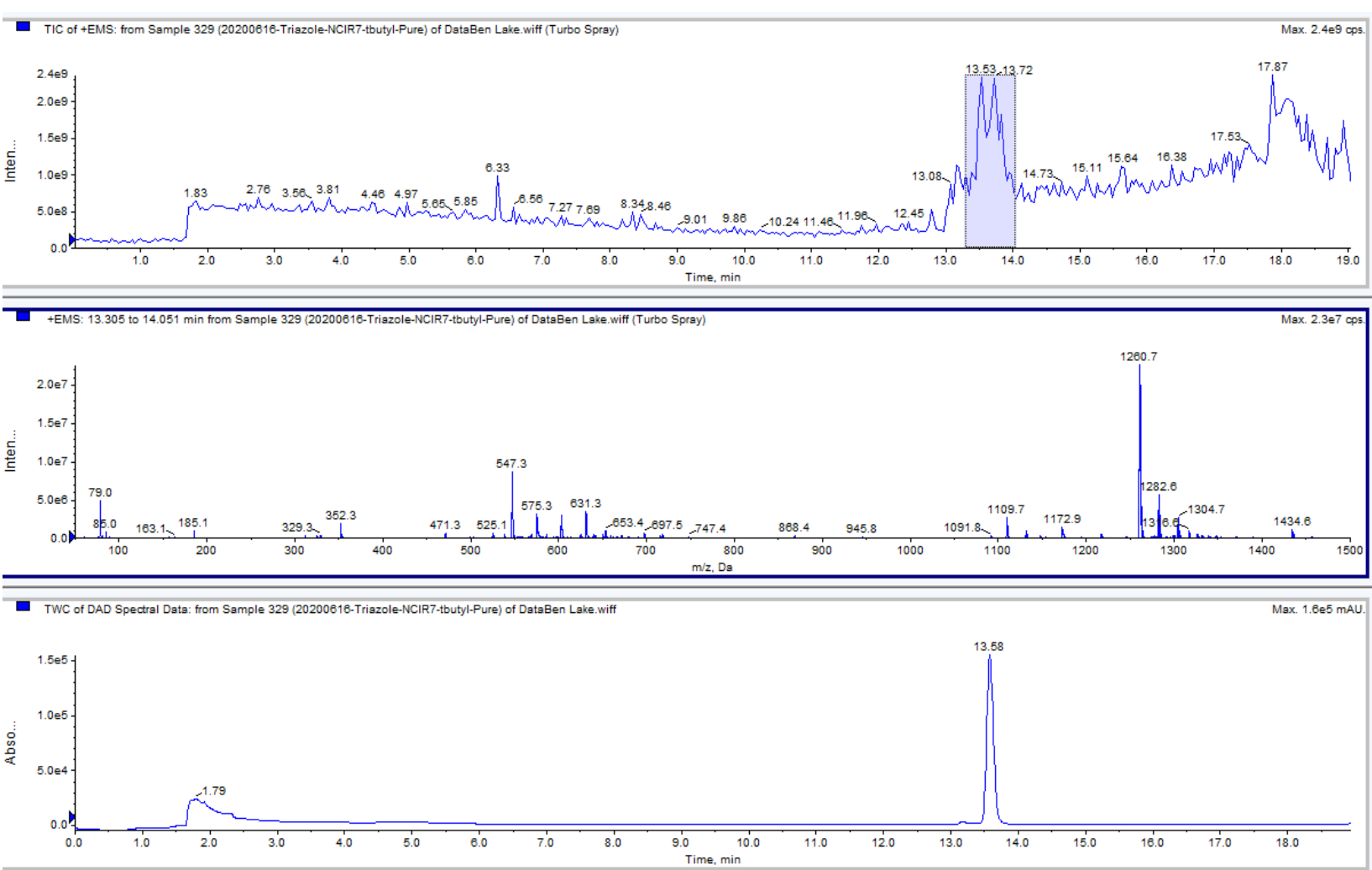

Figure S24. LC-MS trace of post column purified compound 16, (top) TIC trace, (middle) selected mass spectrum from TIC highlighted in blue box on TIC, (bottom) UV chromatogram. 


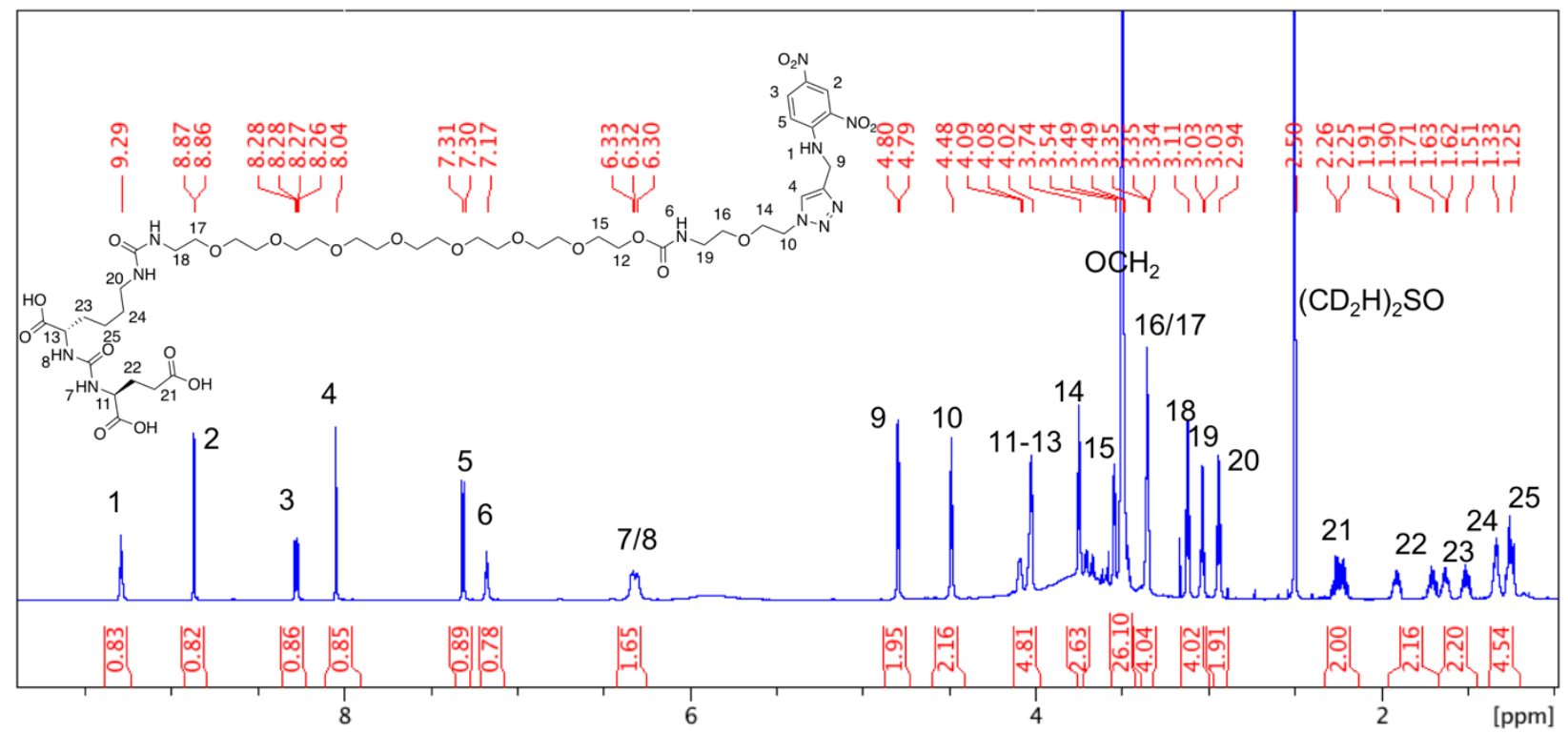

Figure S25. ${ }^{1} \mathrm{H}-\mathrm{NMR}$ of ARM 6, $\left(\mathrm{CD}_{3}\right)_{2} \mathrm{SO}$.

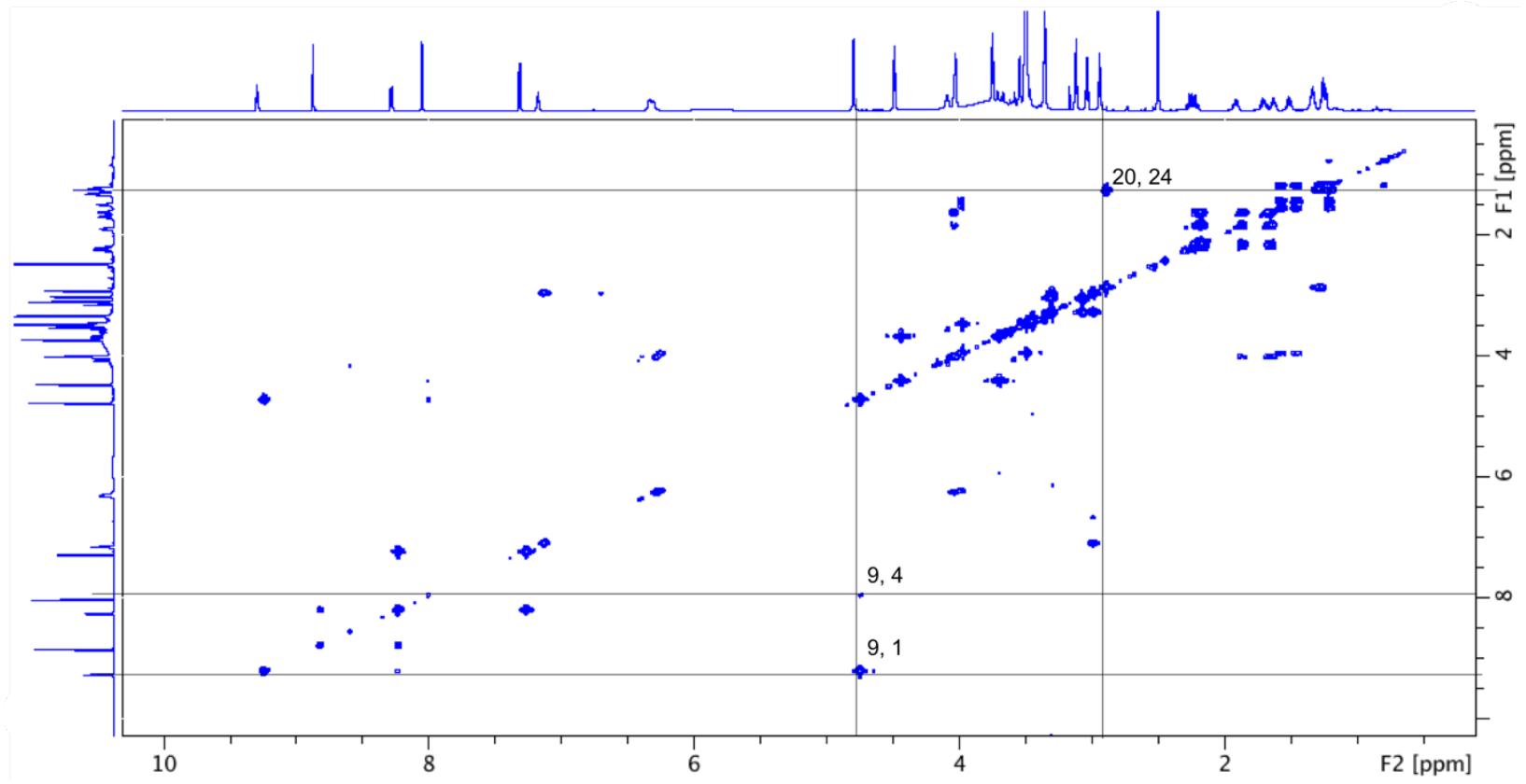

Figure S26. ${ }^{1} \mathrm{H}^{1} \mathrm{H}-\mathrm{COSY} \mathrm{NMR}$ of ARM 6, $\left(\mathrm{CD}_{3}\right)_{2} \mathrm{SO}$. 


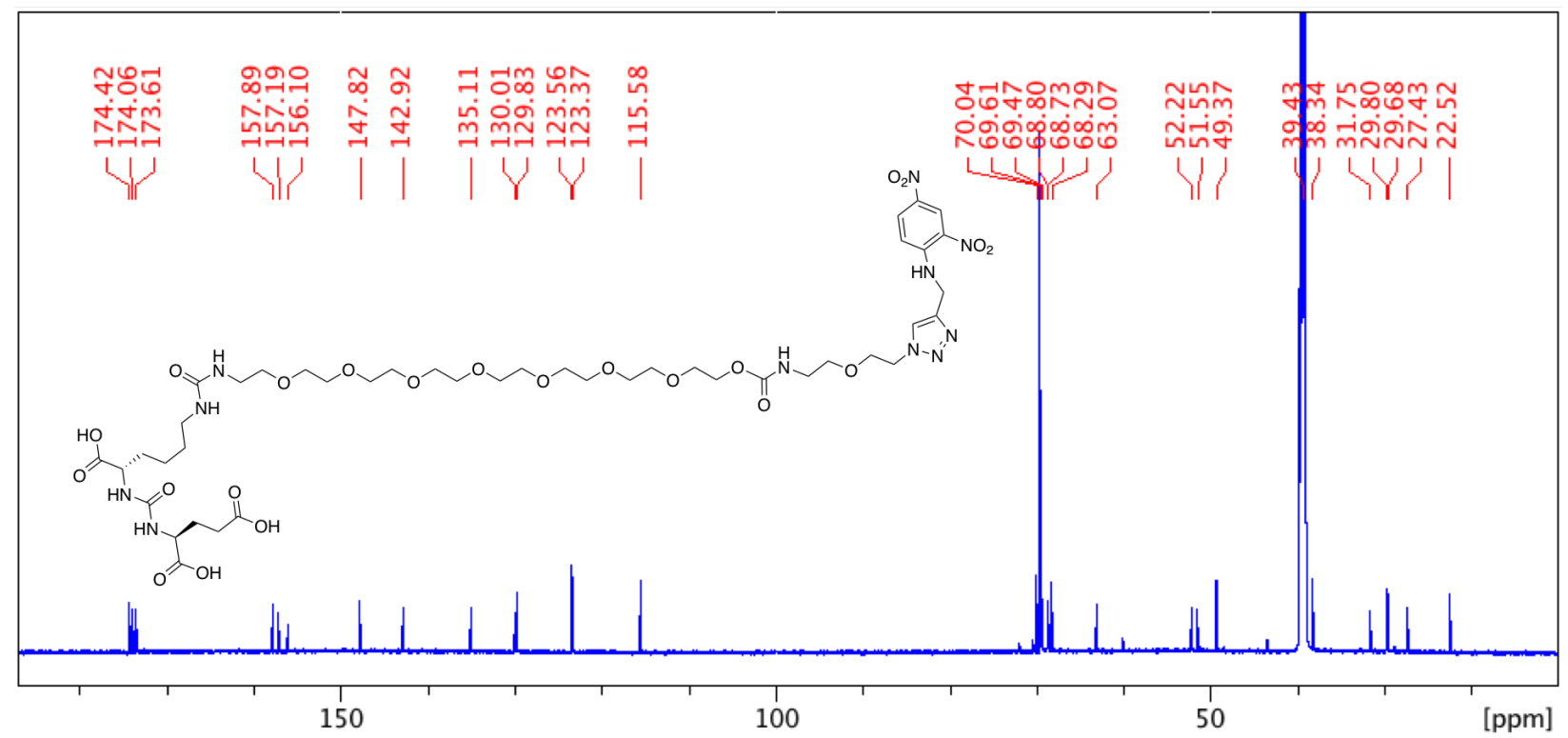

Figure $S 27 .{ }^{13} \mathrm{C}-\mathrm{NMR}$ of ARM6, $\left(\mathrm{CD}_{3}\right)_{2} \mathrm{SO}$. 

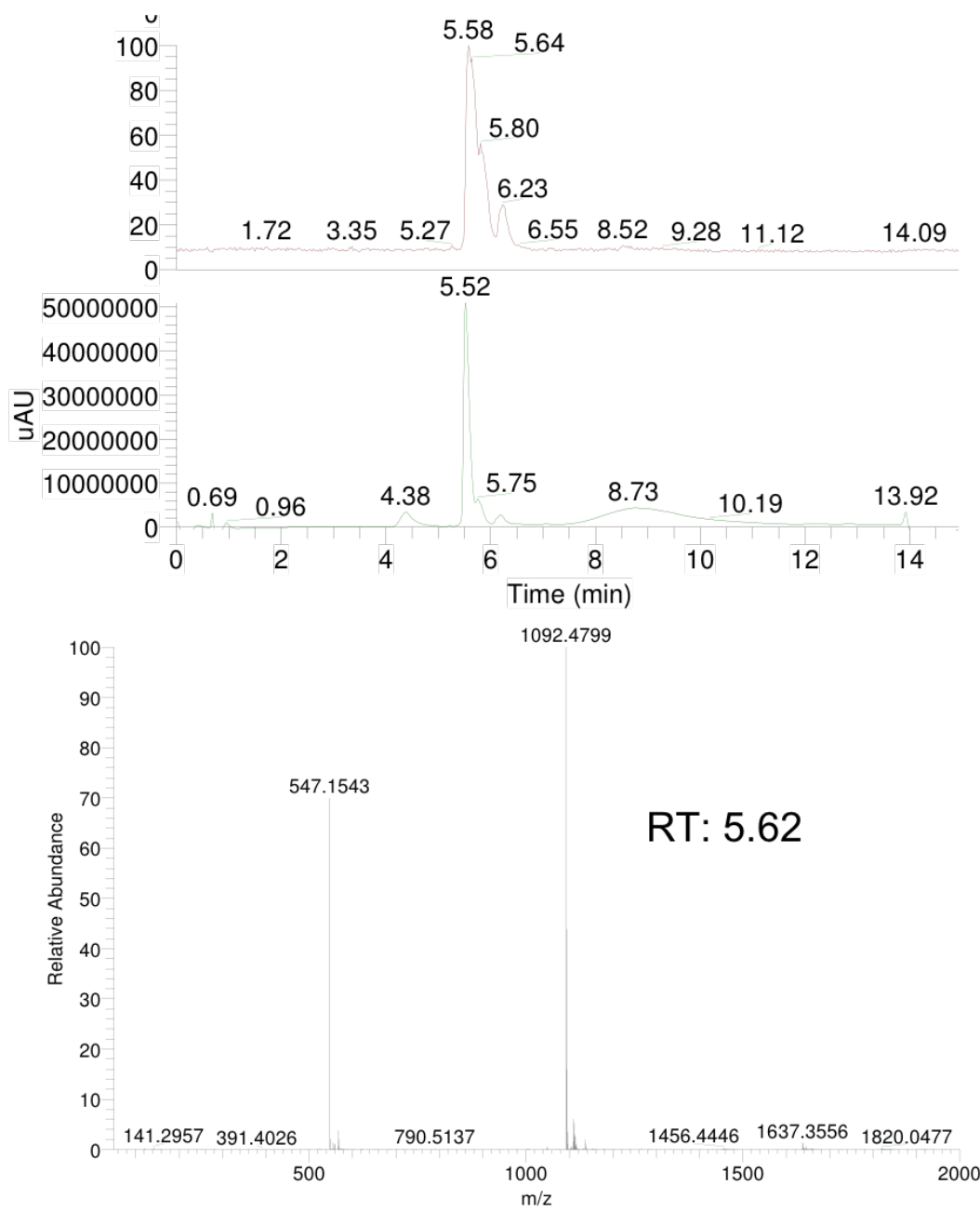

Figure S28. LC-MS trace of post column purified compound ARM 6, (top) TIC trace, (bottom) selected mass spectrum from TIC with retention time (RT) noted, (middle) UV chromatogram. 


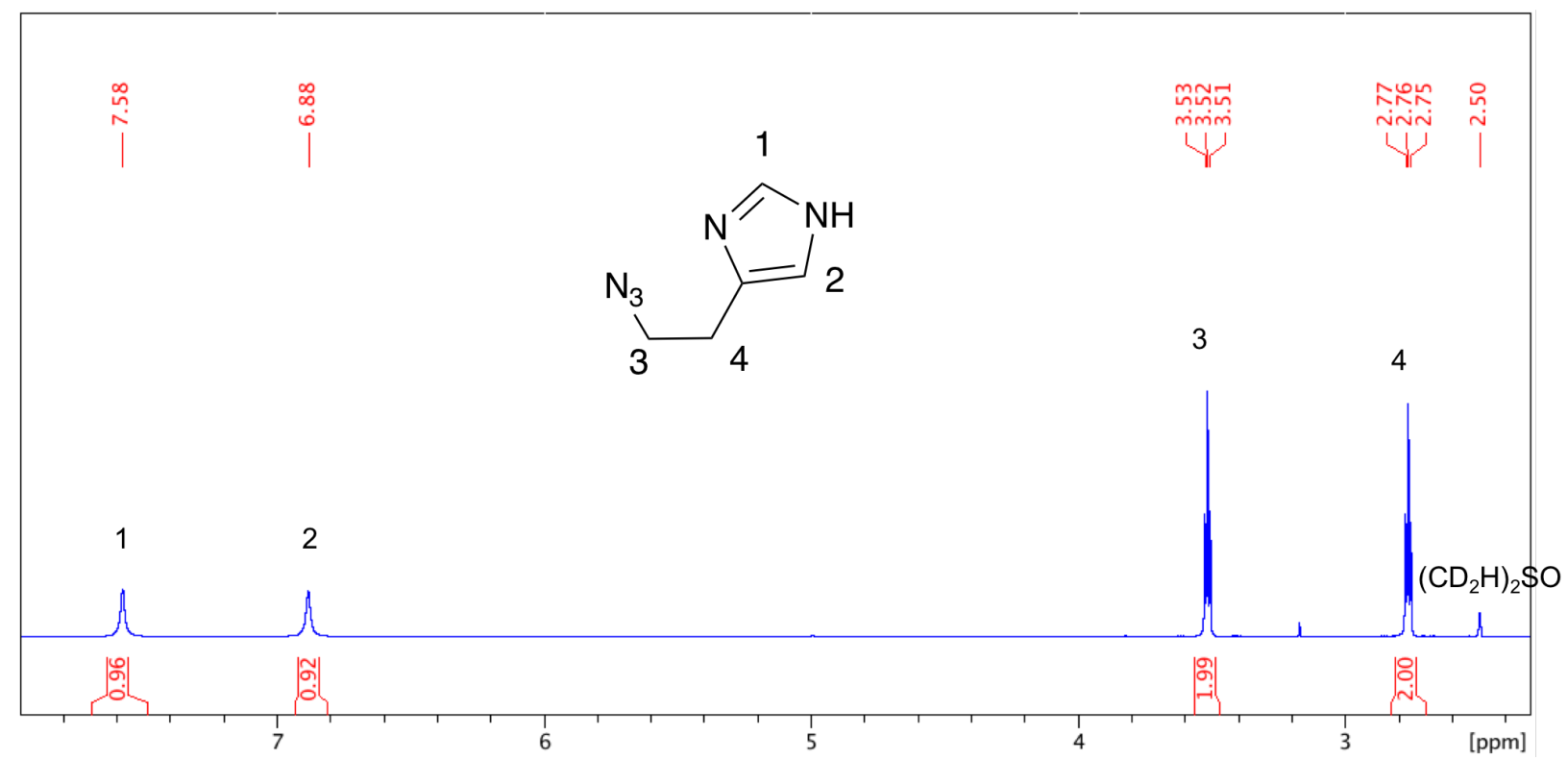

Figure S29. ${ }^{1} \mathrm{H}-\mathrm{NMR}$ of $\mathbf{1 7},\left(\mathrm{CD}_{3}\right)_{2} \mathrm{SO}$.

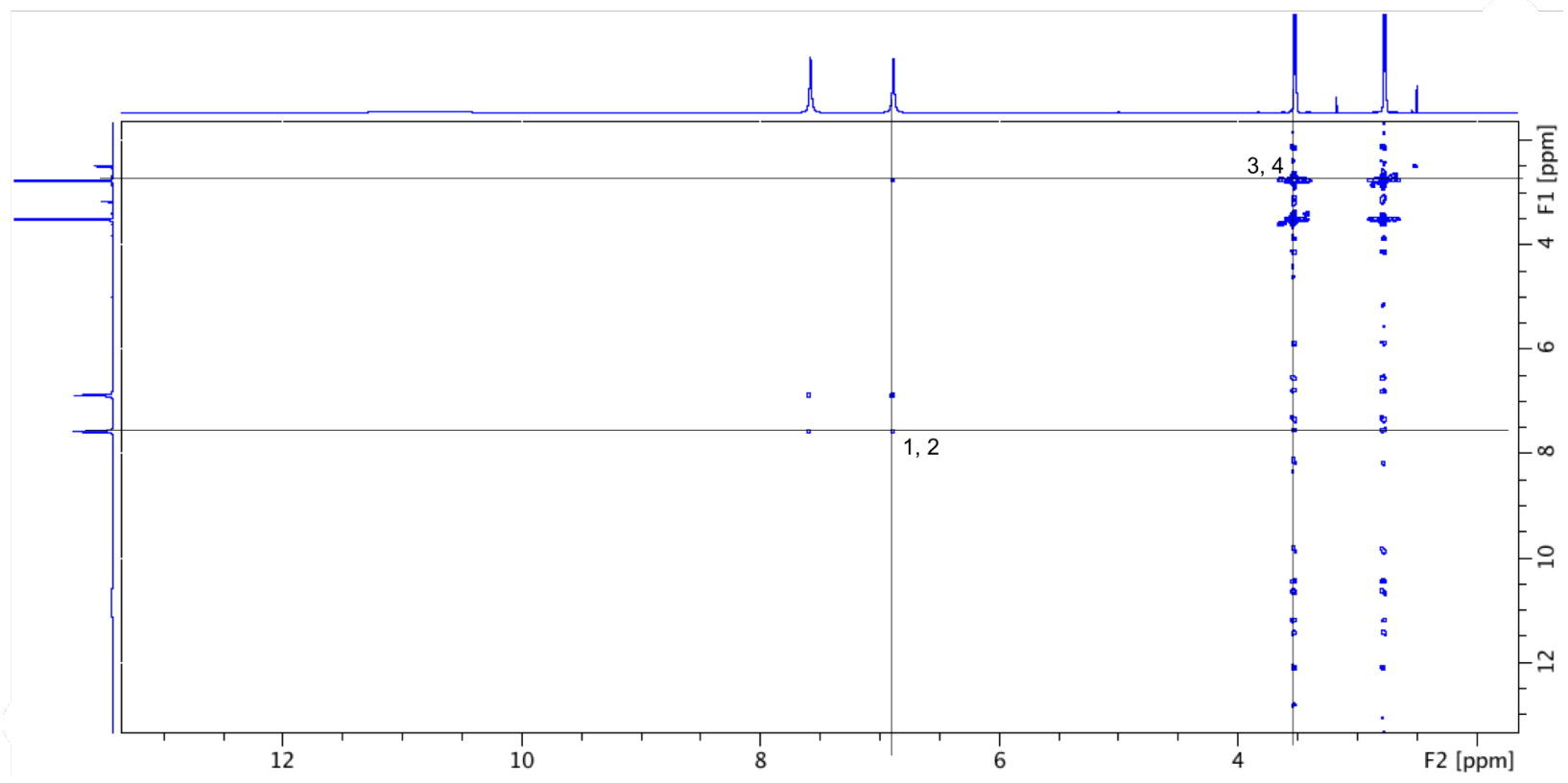

Figure S30. ${ }^{1} \mathrm{H}^{1} \mathrm{H}-\mathrm{COSY} \mathrm{NMR}$ of $\mathbf{1 7},\left(\mathrm{CD}_{3}\right)_{2} \mathrm{SO}$. 


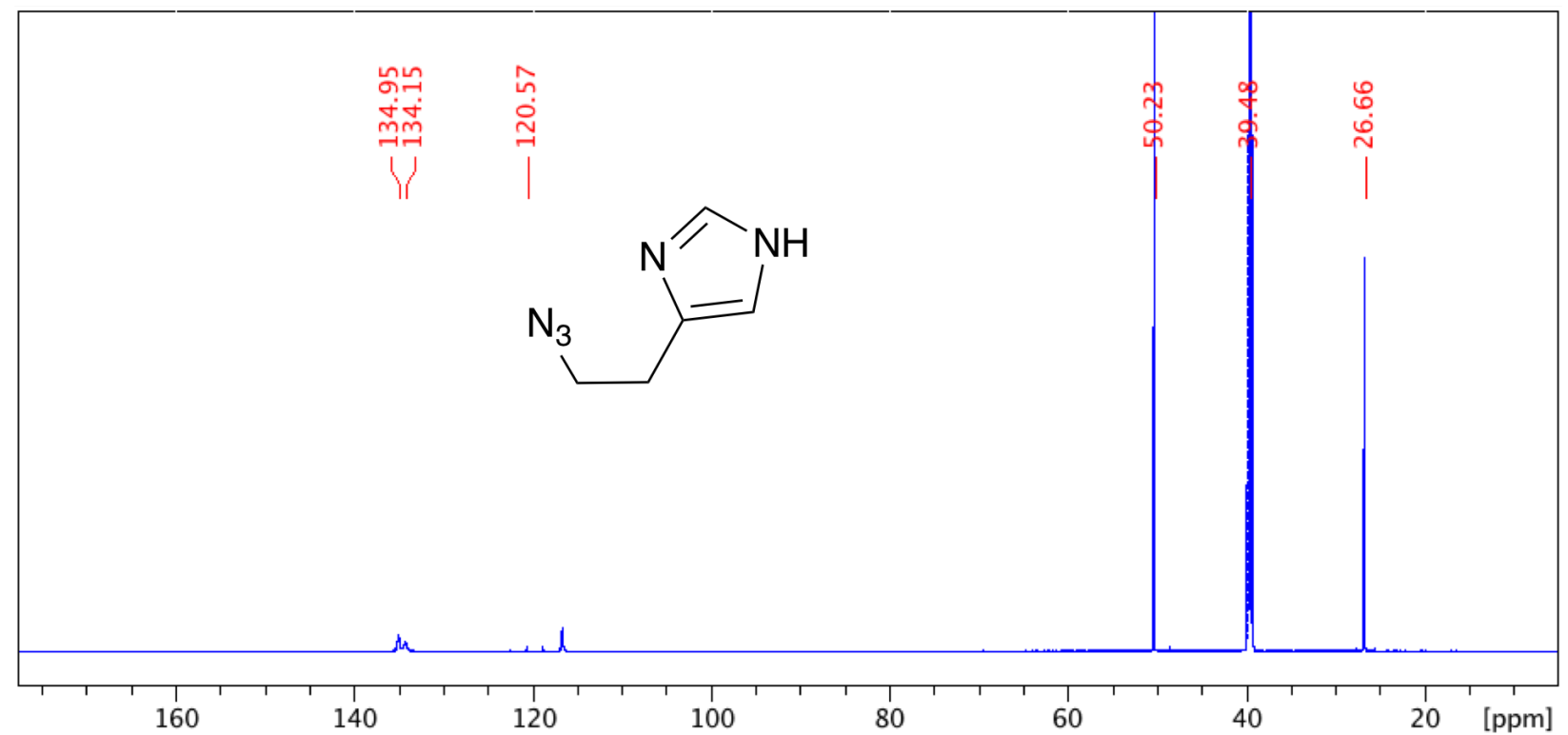

Figure S31. ${ }^{13} \mathrm{C}-\mathrm{NMR}$ of $\mathbf{1 7},\left(\mathrm{CD}_{3}\right)_{2} \mathrm{SO}$.
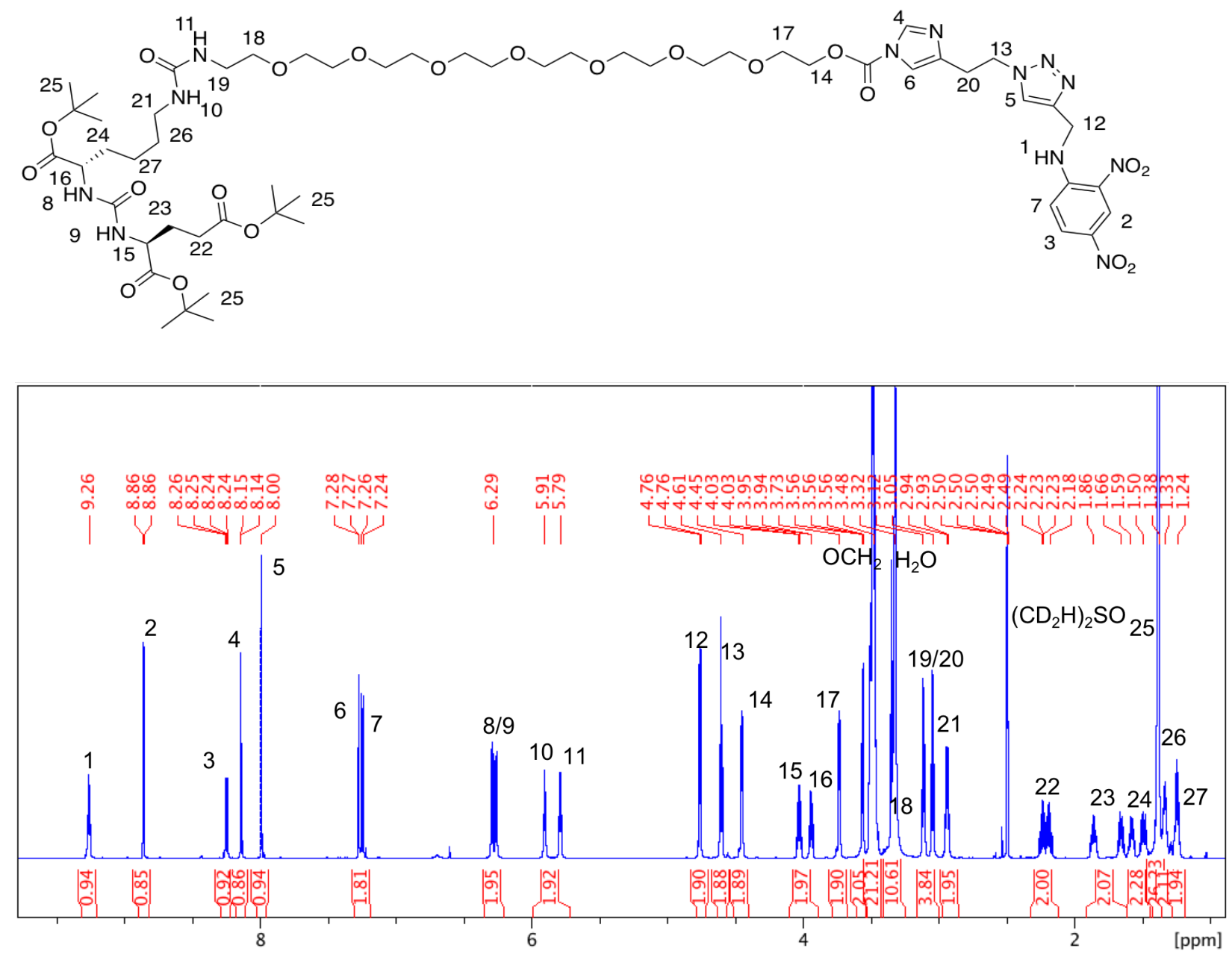
Figure S32. ${ }^{1} \mathrm{H}-\mathrm{NMR}$ of $\mathbf{1 8},\left(\mathrm{CD}_{3}\right)_{2} \mathrm{SO}$.

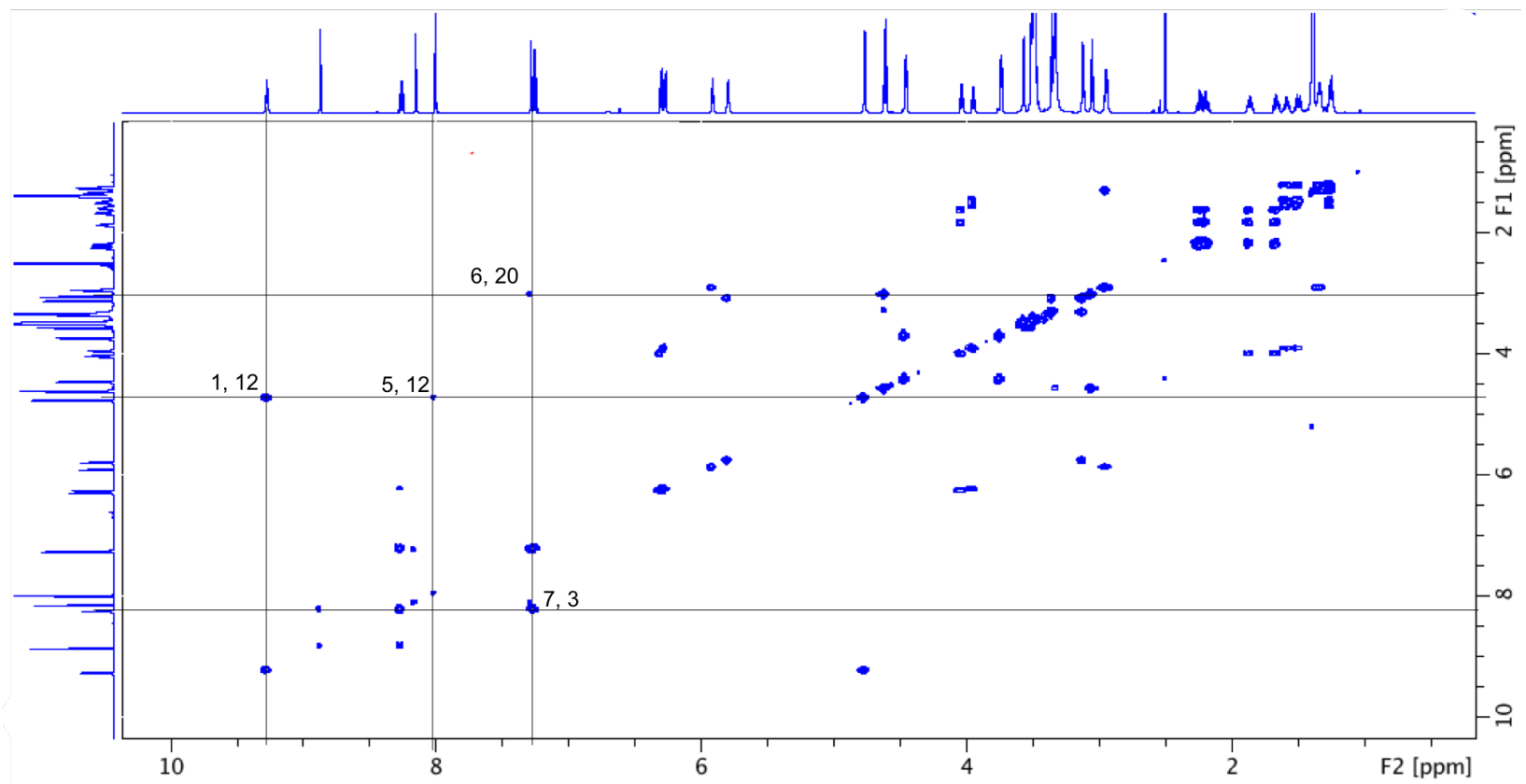

Figure S33. ${ }^{1} \mathrm{H}^{1} \mathrm{H}-\mathrm{COSY} \mathrm{NMR}$ of $\mathbf{1 8},\left(\mathrm{CD}_{3}\right)_{2} \mathrm{SO}$.

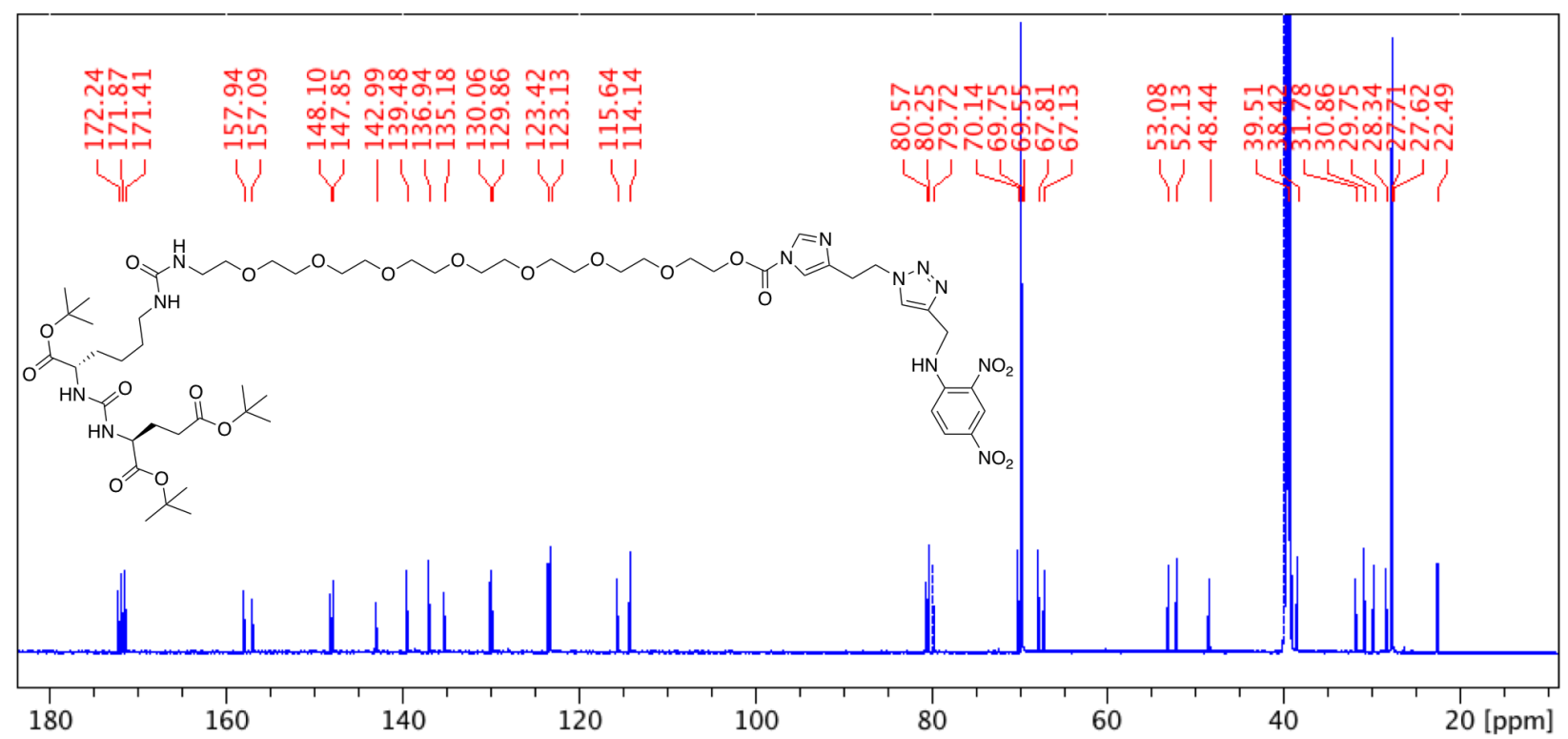

Figure $334 .{ }^{13} \mathrm{C}-\mathrm{NMR}$ of $\mathbf{1 8},\left(\mathrm{CD}_{3}\right)_{2} \mathrm{SO}$. 

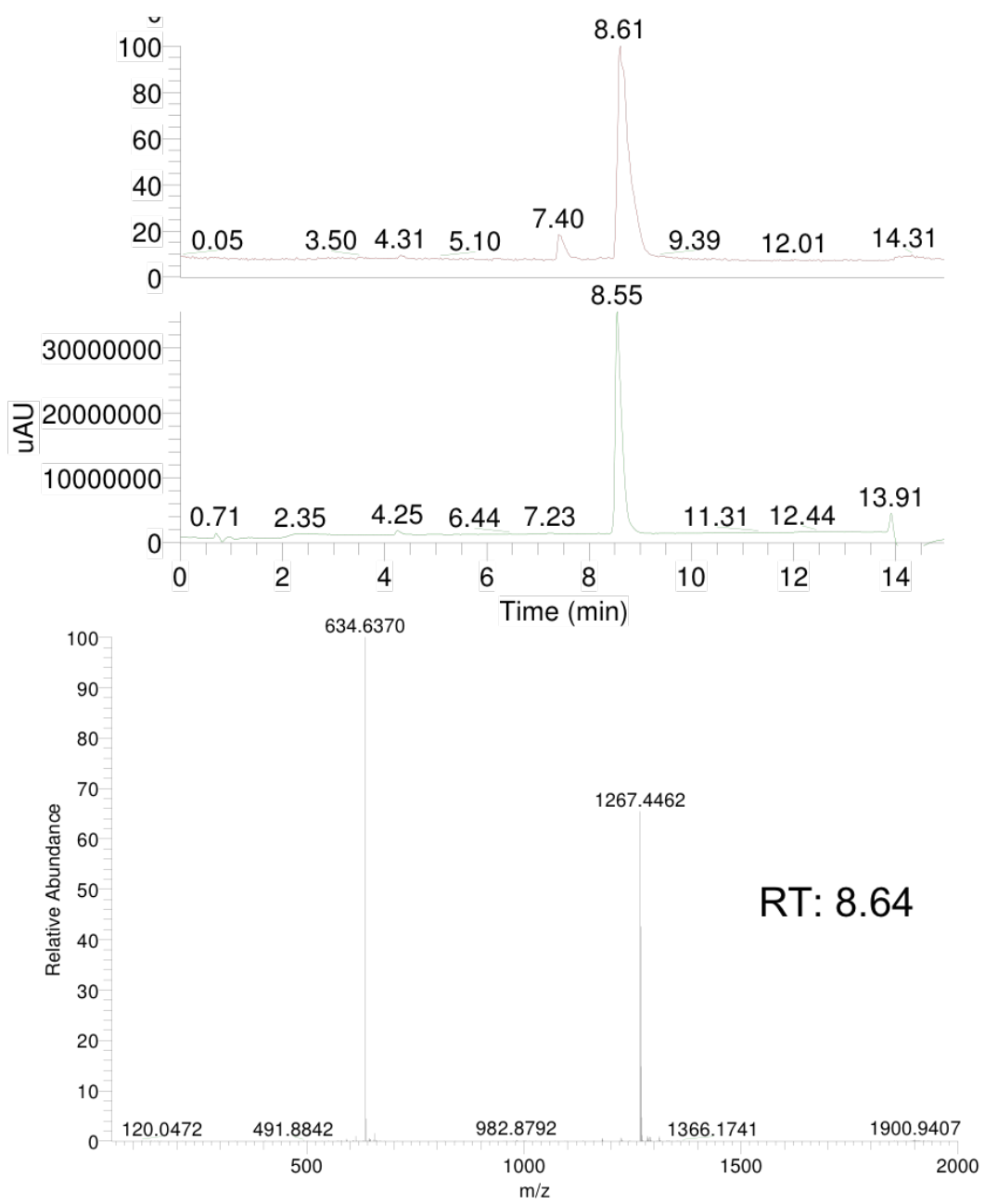

Figure S35. LC-MS trace of post column purified compound 18, (top) TIC trace, bottom) selected mass spectrum from TIC with retention time (RT) noted, (middle) UV chromatogram. 

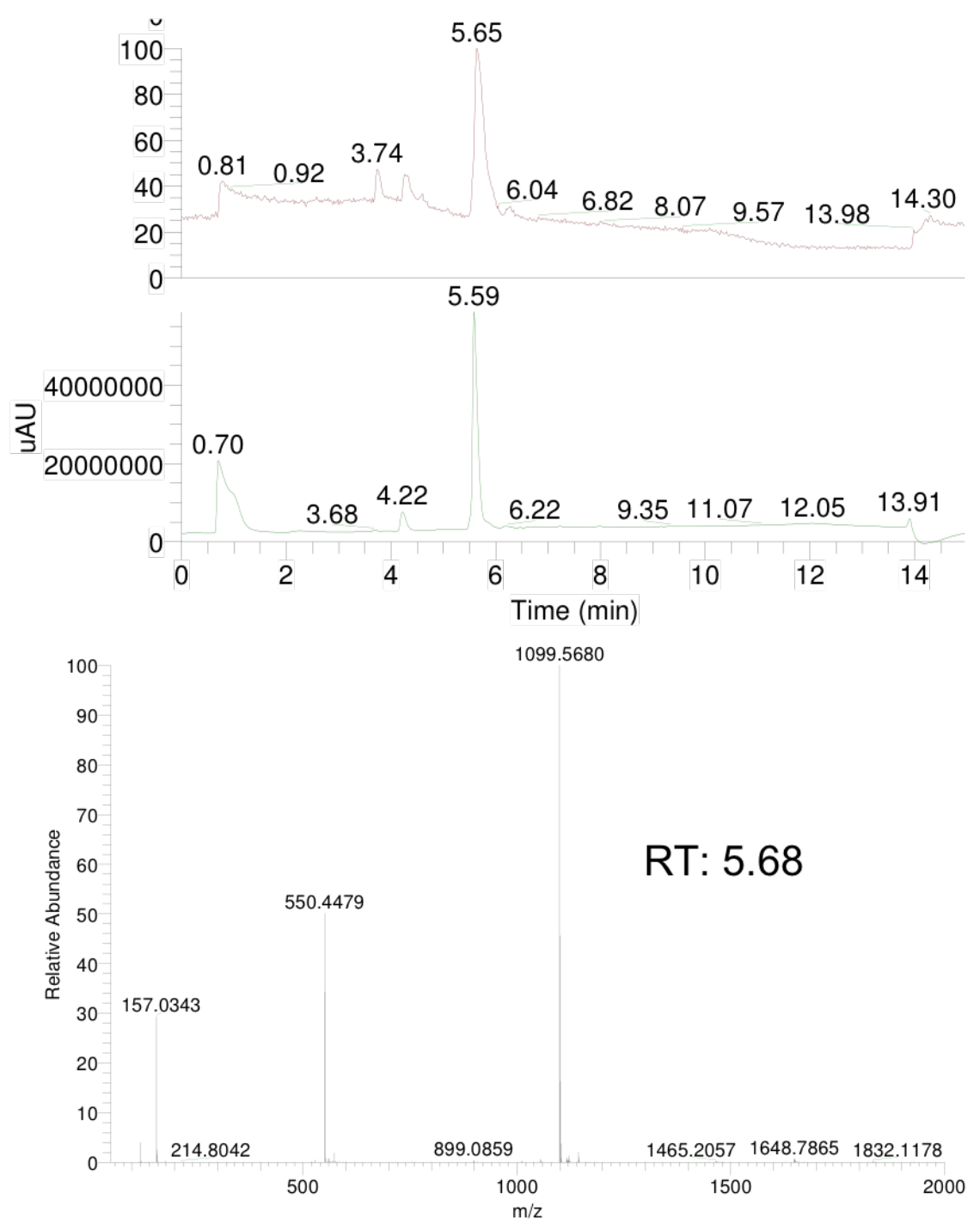

Figure S36. LC-MS trace of post column purified compound cARM5, (top) TIC trace, bottom) selected mass spectrum from TIC with retention time (RT) noted, (middle) UV chromatogram. 


\section{$\underline{\text { References }}$}

(1) Lake, B., Serniuck, N., Kapcan, E., Wang, A., and Rullo, A. F. (2020) Covalent Immune Recruiters: Tools to Gain Chemical Control Over Immune Recognition. ACS Chem. Biol.15, 1089-1095.

(2) Douglass, E. F.,Jr.; Miller, C. J; Sparer, G.; Shapiro, H.; Spiegel, D.A. (2013). A Comprehensive mathematical model for three-body binding equilibria. J Am Chem Soc, 135 (16), 6092-6099

(3) Strelow, J.M. (2016) A Perspective on the Kinetics of Covalent and Irreversible Inhibition. SLAS Discov. 22, 3-20.

(4) Kuzmic, P. (1996) Program DYNAFIT for the Analysis of Enzyme Kinetic Data: Application to HIV Proteinase. Anal. Biochem. 237, 260-273.

(5) Price, K.V., Storn, R.M., Lampinen, J.A. (2005). Differential Evolution: A Practical Approach to Global Optimization. Springer Verlag, New York

(6) Gonzalez-Quintela, A., Alende, R., Gude, F., Campos, J., Rey, J., Meijide, LM., Fernandez-Merino, C., and Vidal, C. (2008) Serum levels of immunoglobulins (IgG, IgA, IgM) in a general adult population and their relationship with alcohol consumption, smoking and common metabolic abnormalities. Clin Exp Immunol. 151, 42-50. 